\title{
Summary of Data Concerning Radiological Contamination at Well PM-2, Nevada Test Site, Nye County, Nevada
}

\author{
By Gary M. Russell and Glenn L. Locke
}

U.S. GEOLOGICAL SURVEY

Open-File Report 96-599

Prepared in cooperation with the U.S. DEPARTMENT OF ENERGY, under

Interagency Agreement DE-Al08-91NV11040

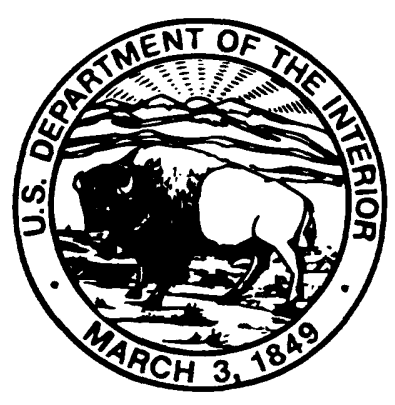

Carson City, Nevada 1997 


\title{
U.S. DEPARTMENT OF THE INTERIOR BRUCE BABBITT, Secretary
}

\author{
U.S. GEOLOGICAL SURVEY \\ GORDON P. EATON, Director
}

Any use of trade names in this publication is for descriptive purposes

only and does not constitute endorsement by the U.S. Government

For additional information write to:

District Chief

U.S. Geological Survey

333 West Nye Lane, Room 203

Carson City, NV 89706-0866
Copies of this report can be purchased from:

U.S. Geological Survey

Branch of Information Services

Box 25286, MS 517

Denver, CO 80225-0046 


\section{CONTENTS}

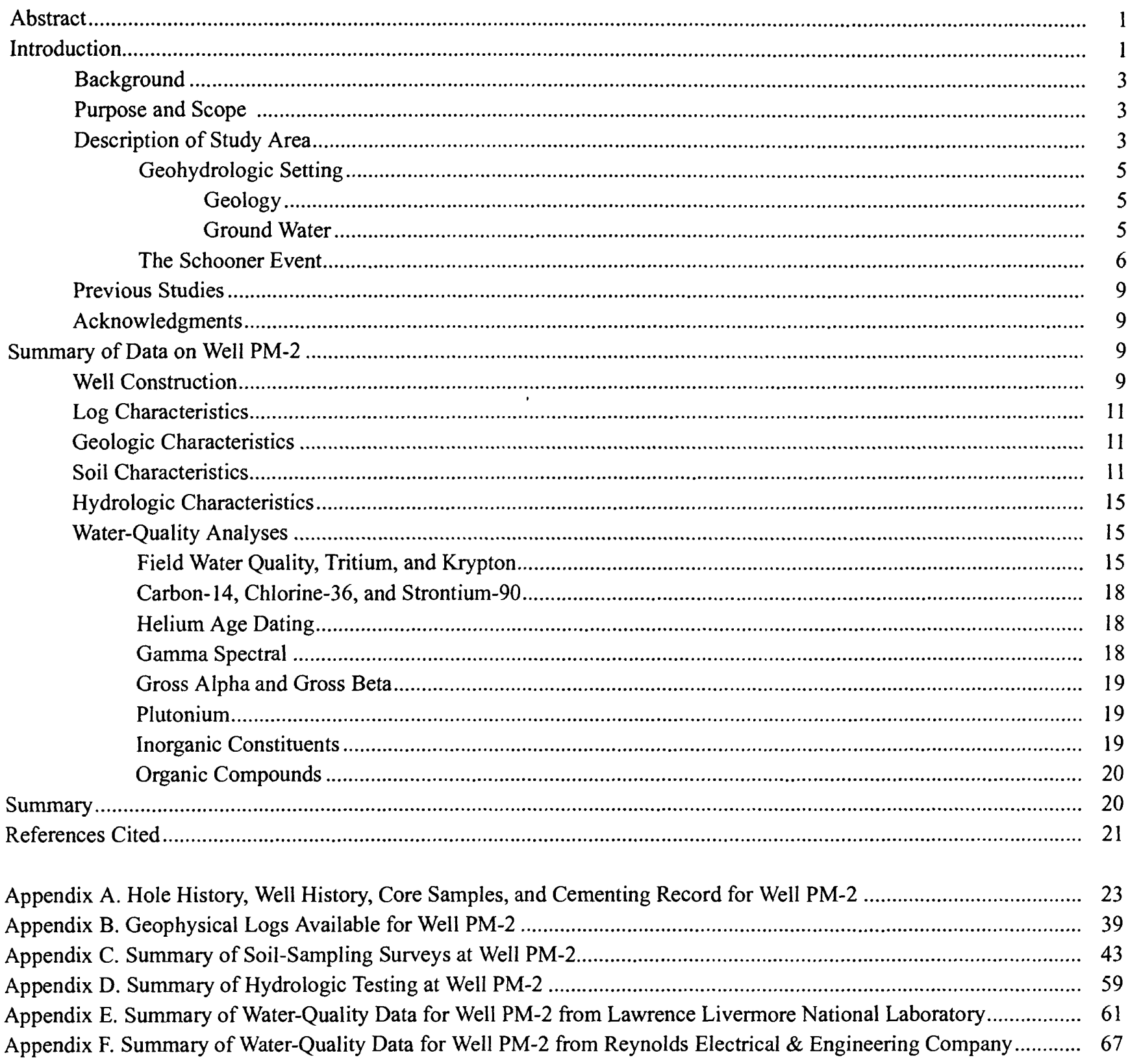

\section{FIGURES}

1-2. Maps showing:

1. Death Valley ground-water-flow system and subbasins, southern Nevada and eastern California, showing location of Nevada Test Site and well PM-2

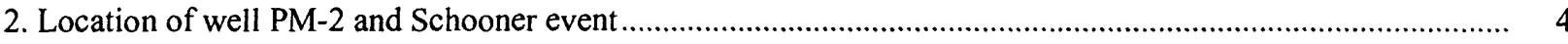

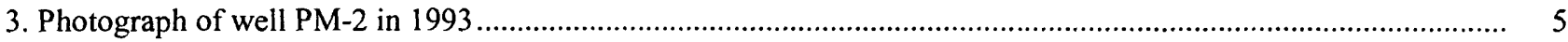

4. Hydrograph showing measurements of depth to water in well PM-2, 1983-94 ....................................................... 6

5. Map showing water-level contours in eastern Pahute Mesa ......................................................................... 7

6. Aerial photograph of Schooner crater in 1989, showing extent of ejecta and location of well PM-2 ...................... 8 
7-9. Diagrams showing well PM-2:

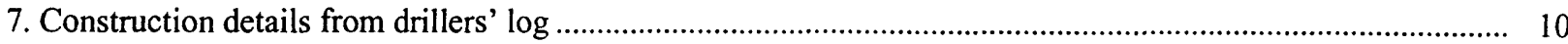

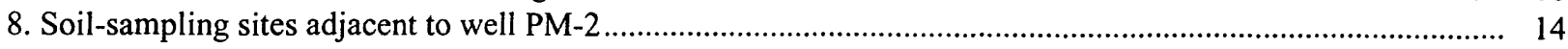

9. Water-quality data collected August 17, 1993, and September 27, 1993................................................... 16

\section{TABLES}

1. Summary of lithologic log of well PM-2

2. Soil moisture, tritium, and gamma spectroscopy analysis of soil samples around well PM-2, November 19, $1993 \ldots 13$

3. Summary of water-level measurements at well PM-2, 1983-94 ..................................................................... 15

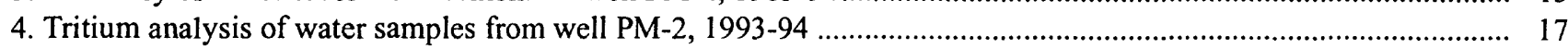

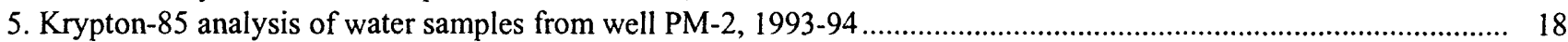

6. Analysis of carbon-14, chlorine-36, and strontium-90 in water samples from well PM-2,

November 29-December 1, 1993

7. Helium- 3 and helium- 4 analyses used to determine age of water samples from well PM-2,

November 29-December 1, 1993

8. Gamma spectral analysis of water samples from well PM-2, 1993-94 _.......................................................... 19

9. Analysis of combined plutonium-238 and plutonium-239 in raw water samples from well PM-2, May 3-4, 1994 .... 19

10. Volatile and semivolatile organic compounds in water samples from well PM-2, November 29-December 1, 1993 .. 21

\section{CONVERSION FACTORS AND VERTICAL DATUM}

\begin{tabular}{rll}
\hline Multiply & By & To obtain \\
\hline becquerel $(\mathrm{Bq})$ & 27.027 & picocurie \\
centimeter $(\mathrm{cm})$ & 0.3937 & inch \\
gram $(\mathrm{g})$ & 0.03527 & ounce avoirdupois \\
kilometer $(\mathrm{km})$ & 0.62137 & mile \\
$\operatorname{meter}(\mathrm{m})$ & 3.281 & feet \\
square kilometer $\left(\mathrm{km}^{2}\right)$ & 0.3861 & square mile \\
\hline
\end{tabular}

Temperature: Degrees Celsius $\left({ }^{\circ} \mathrm{C}\right)$ can be converted to degrees Fahrenheit $\left({ }^{\circ} \mathrm{F}\right)$ by using the formula ${ }^{\circ} \mathrm{F}=\left[1.8\left({ }^{\circ} \mathrm{C}\right)\right]+32$.

Sea level: In this report, "sea level" refers to the National Geodetic Vertical Datum of 1929 (NGVD of 1929, formerly called "Sea-Level Datum of 1929"), which is derived from a general adjustment of the first-order leveling networks of the United States and Canada.

\section{Chemical symbols used in text:}

\begin{tabular}{|c|c|c|c|c|c|}
\hline $\mathrm{Ag}$ & silver & $\mathrm{Fe}$ & iron & $\mathrm{Pb}$ & lead \\
\hline $\mathrm{Al}$ & aluminum & $\mathrm{Ge}$ & germanium & $\mathrm{Pu}$ & plutonium \\
\hline Am & americium & $\mathrm{He}$ & helium & $\mathrm{Ra}$ & radium \\
\hline B & boron & $\mathrm{Hg}$ & mercury & $\mathrm{S}$ & sulfur \\
\hline $\mathrm{Ba}$ & barium & K & potassium & $\mathrm{Sb}$ & antimony \\
\hline $\mathrm{C}$ & carbon & $\mathrm{Kr}$ & krypton & $\mathrm{Se}$ & selenium \\
\hline $\mathrm{Ca}$ & calcium & $\mathrm{Li}$ & lithium & $\mathrm{Si}$ & silicon \\
\hline $\mathrm{Cl}$ & chlorine & $\mathrm{Mg}$ & magnesium & $\mathrm{Sr}$ & strontium \\
\hline Co & cobalt & $\mathrm{Mn}$ & manganese & Th & thorium \\
\hline $\mathrm{Cr}$ & chromium & Mo & molybdenum & ${ }^{3} \mathrm{H}$ & tritium \\
\hline $\mathrm{Cs}$ & cesium & $\mathrm{Na}$ & sodium & U & uranium \\
\hline $\mathrm{Cu}$ & copper & $\mathrm{Ni}$ & nickel & $\mathrm{Zn}$ & zinc \\
\hline $\mathrm{Eu}$ & europium & $\mathrm{P}$ & phosphorus & & \\
\hline
\end{tabular}




\title{
Summary of Data Concerning Radiological Contamination at Well PM-2, Nevada Test Site, Nye County, Nevada
}

\author{
By Gary M. Russell and Glenn L. Locke
}

\section{ABSTRACT}

Analysis of water from well Pahute Mesa No. 2 (PM-2), on Pahute Mesa in the extreme northwestern part of the Nevada Test Site, indicated tritium concentrations above background levels in August 1993. A coordinated investigation of the tritium occurrence in well PM-2 was undertaken by the Hydrologic Resources Management Program of the U.S. Department of Energy. Geologic and hydrologic properties of the hydrogeologic units were characterized using existing information. Soil around the well and water quality in the well were characterized during the investigation.

The nearest underground test in the immediate area of well PM-2 was the 1968 Schooner event (U-20u), detonated approximately 270 meters southeast of the well PM-2 at a depth of 108.2 meters. The crater created by the Schooner event is about 129.8 meters in radius and 63.4 meters in depth. The continuous-ejecta limit (the outermost limit of continuous deposits of earth materials thrown out and away from the explosion) was asymmetrical, ranging in radius from about 518 to 823 meters. The maximum extent of ejected earth materials exceeded 1,830 meters.

Results of soil sampling indicate that radioactivity of identifiable nonnaturally occurring fission and activation products (americium-241, cobalt-60, cesium-137, europium-150, europium152 , and europium-154) were the same order of magnitude as that of the natural radiation (krypton40, radium-226, thorium-228, thorium-232). Gamma spectrum analysis of each soil sample had numerous unidentified peaks with high counting errors.
Close agreement between tritium analyses of water from well PM-2, at different times and at the same depths, confirms the elevated levels of tritium. The highest tritium values in the borehole were at 610 meters below land surface - above the shallowest perforations at 765 meters below land surface. These values were only slightly higher than values found at greater depth in the well.

Values for gamma spectral analysis of water samples were near or below detection limits with the exception of radium-226 at 305 and 823 meters below land surface. Radium-226 is probably a natural decay product from uranium-238. Laboratory analysis indicates that the gamma radiation in well PM-2 was minor.

\section{INTRODUCTION}

The Nevada Test Site (NTS) includes about $3,600 \mathrm{~km}^{2}$ in Nye County, southern Nevada, and is about $105 \mathrm{~km}$ northwest of Las Vegas (fig. 1). NTS is surrounded on the north, east, and west by Nellis Air Force Range (NAFR). This combination of federally owned lands constitutes the largest unpopulated area in the Nation, covering about $14,200 \mathrm{~km}^{2}$. The NTS was established in December 1950 as the principal location for national testing of nuclear devices. The first nuclear test occurred on January 27, 1951. The first underground nuclear test occurred on November 29, 1951. Since July 11, 1962, all nuclear tests in the United States have been detonated underground; most of them at NTS. A total of 928 nuclear tests have been conducted at NTS -100 tests were atmospheric and 828 were underground (U.S. Department of Energy, 1994). Four major areas were used for testing: Frenchman Flat, Yucca Flat, Rainier Mesa, and Pahute Mesa (fig. 1). 


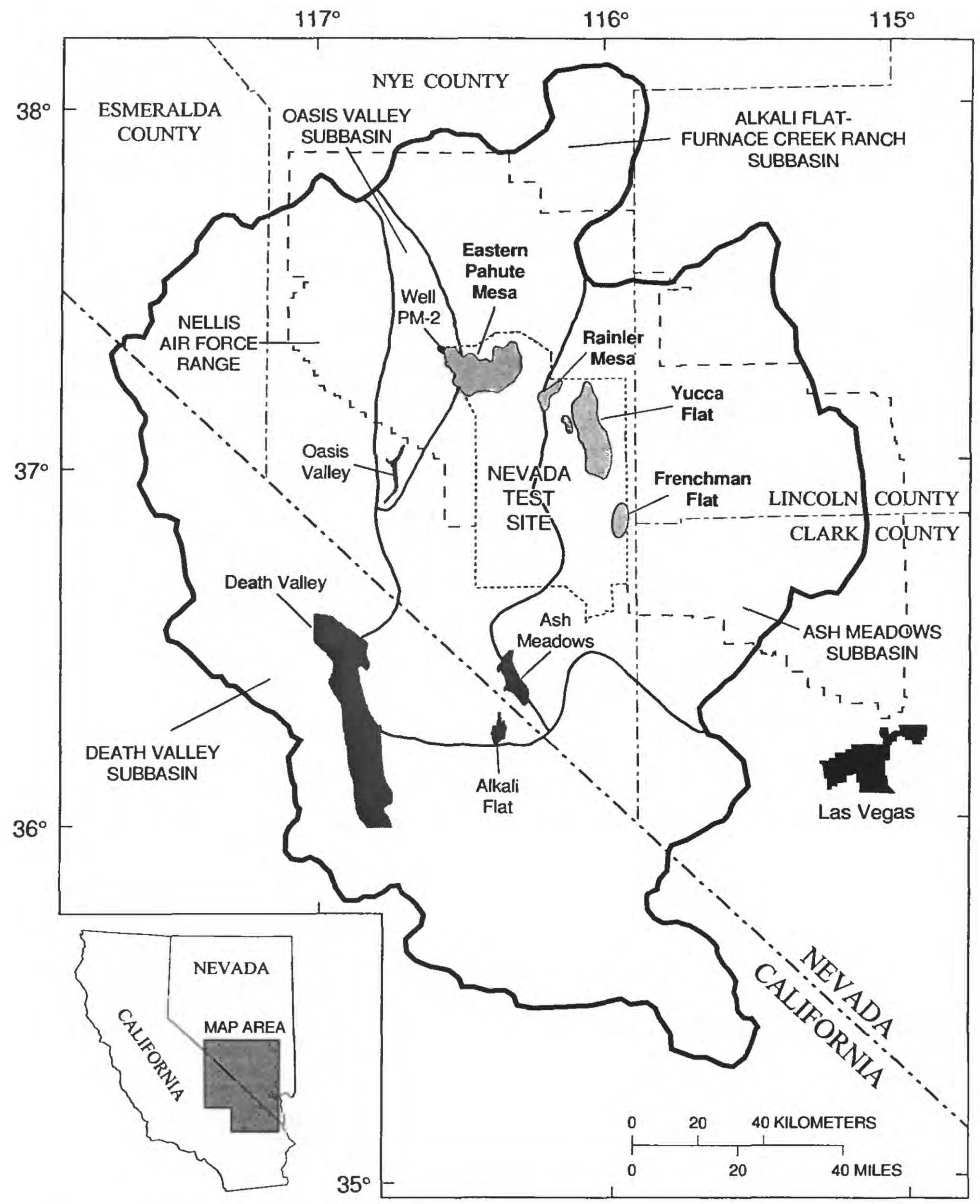

Base prepared by U.S. Geological Survey
from digital data, 1:100,000 1979-89
Universal Transverse Mercator Projection
Zone 11

Figure 1. Death Valley ground-water-flow system and subbasins, southern Nevada and eastern California, showing location of Nevada Test Site and well PM-2 (compiled from Laczniak and others, 1996). 


\section{Background}

Well Pahute Mesa No. 2 (PM-2) is on eastern Pahute Mesa in the extreme northwestern corner of Area 20 approximately $105 \mathrm{~m}$ south of the northern NTS boundary and $275 \mathrm{~m}$ northeast of the western boundary (figs. 2 and 3). On May 20, 1993, the water level in well PM-2 was measured at $254.96 \mathrm{~m}$ below land surface, $4.77 \mathrm{~m}$ higher than a measurement 1 year earlier (fig. 4). During the 10 years prior to May 1993, the water level had not been detected to fluctuate more than $0.65 \mathrm{~m}$. Projections of the rate of decline, following the high measurement, suggested the water level would return to pre-May 1993 levels in approximately 2 years.

The unexpected rise in water level and the ensuing, steady decline indicated that recharge may have taken place. In August 1993, the U.S. Geological Survey collected water samples for analysis of field characteristics, including specific conductance, to determine if the rise and subsequent decline in the water level might have been caused by recharge through the well bore rather than through the aquifer. Water samples were delivered to the Environmental Monitoring Systems Laboratory - Las Vegas (EMSL) of the U.S. Environmental Protection Agency (USEPA) for radiological testing. USEPA analysis indicated ${ }^{3} \mathrm{H}$ concentrations of $21,000 \mathrm{~Bq} / \mathrm{L}$. Possible sources of contamination of the water from well PM-2 include (1) prompt injection at the time of the Schooner event; (2) recharge from the Schooner crater; (3) water introduced during drilling and hydraulic testing of well PM-2; (4) migration of contamination from Schooner or other underground tests; (5) contaminated materials disposed of in the well; and (6) recharge through the borehole.

The U.S. Geological Survey (USGS) was directed by the U.S. Department of Energy (USDOE) under interagency agreement DE-AI08-91NV11040, as a part of the existing Hydrologic Resources Manage-

\section{EXPLANATION}

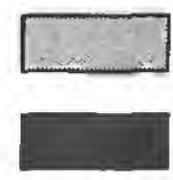

Area used for nuclear testing

Ground-water discharge area in Death Valley flow system

Approximate boundary of Death Valley ground-water flow system-Subbasins within flow system are indicated ment Program (HRMP), to participate in investigating the occurrence of tritiated waters in well PM-2. Other HRMP member agencies involved with the investigation included Lawrence Livermore National Laboratory (LLNL), Los Alamos National Laboratory (LANL), Desert Research Institute (DRI), and Reynolds Electrical and Engineering Co. (REECo).

\section{Purpose and Scope}

The purpose of this report is to present existing information and results from a coordinated investigation of ${ }^{3} \mathrm{H}$ occurrence in well PM- 2 by the HRMP. The objectives of the overall investigation include (1) determination of the type and concentration of contamination, (2) identification of the source and mechanism of contamination, (3) estimation of the extent of radiological contamination, (4) initiation of appropriate monitoring of the contamination, and (5) reporting of investigation results. This report addresses objective five. Compiled and tabulated data of the area are presented. The report also includes characterization of geology, soil, hydrology, and water-quality data.

The six appendices herein, as well as tables 2 and 4-10, present data and information provided by several agencies. Nomenclature reproduced in the appendices does not necessarily conform to terminology used by the U.S. Geological Survey. Likewise, numerical data presented in the appendices and in tables 2 and 4-10 do not necessarily conform to U.S. Geological Survey guidelines with regard to the reporting of significant figures. Procedures used to collect, process, and analyze the samples for which data are listed in the appendices and in tables 2 and 4-10 do not necessarily conform to U.S. Geological Survey protocols and guidelines.

\section{Description of Study Area}

The NTS lies in the Basin and Range physiographic province. The study area is in the northwest part of NTS, in eastern Pahute Mesa. The area consists of broad mesas and volcanic ranges where pre-shot topography was flat, reflecting the nearly flat-lying ashfall tuffs that cover the area around PM-2. Altitudes range from less than $1,600 \mathrm{~m}$ to more than $2,200 \mathrm{~m}$ above sea level in Areas 19 and 20. Land-surface altitude at well PM-2 is $1,703.5 \mathrm{~m}$. The well is located at Nevada State Plane coordinates N. 944,582 and E. 528,655. Mean annual precipitation on eastern 

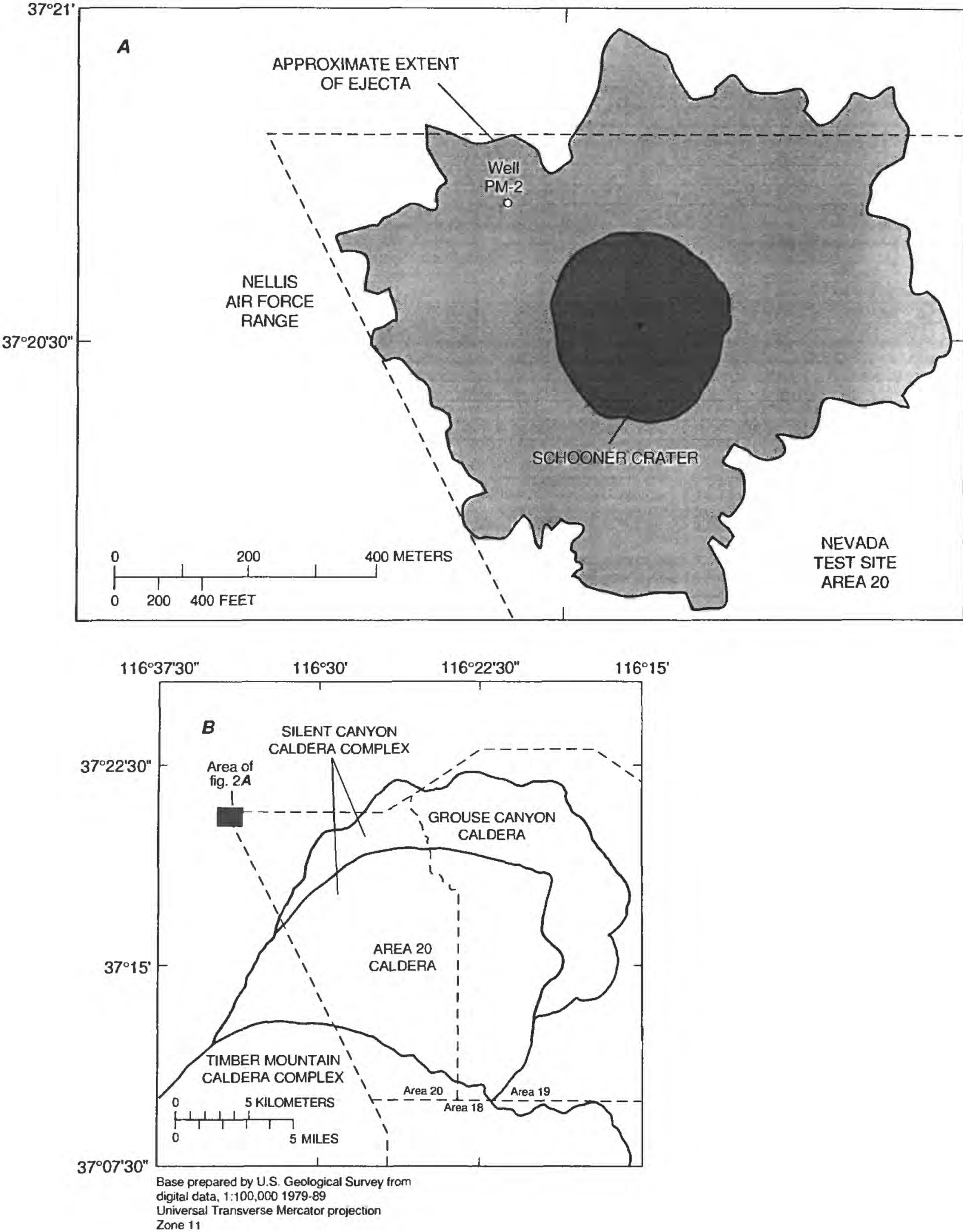

Figure 2. LDcation of well PM-2 and Schooner event. Extent of ejecta also is shown in figure 5. 


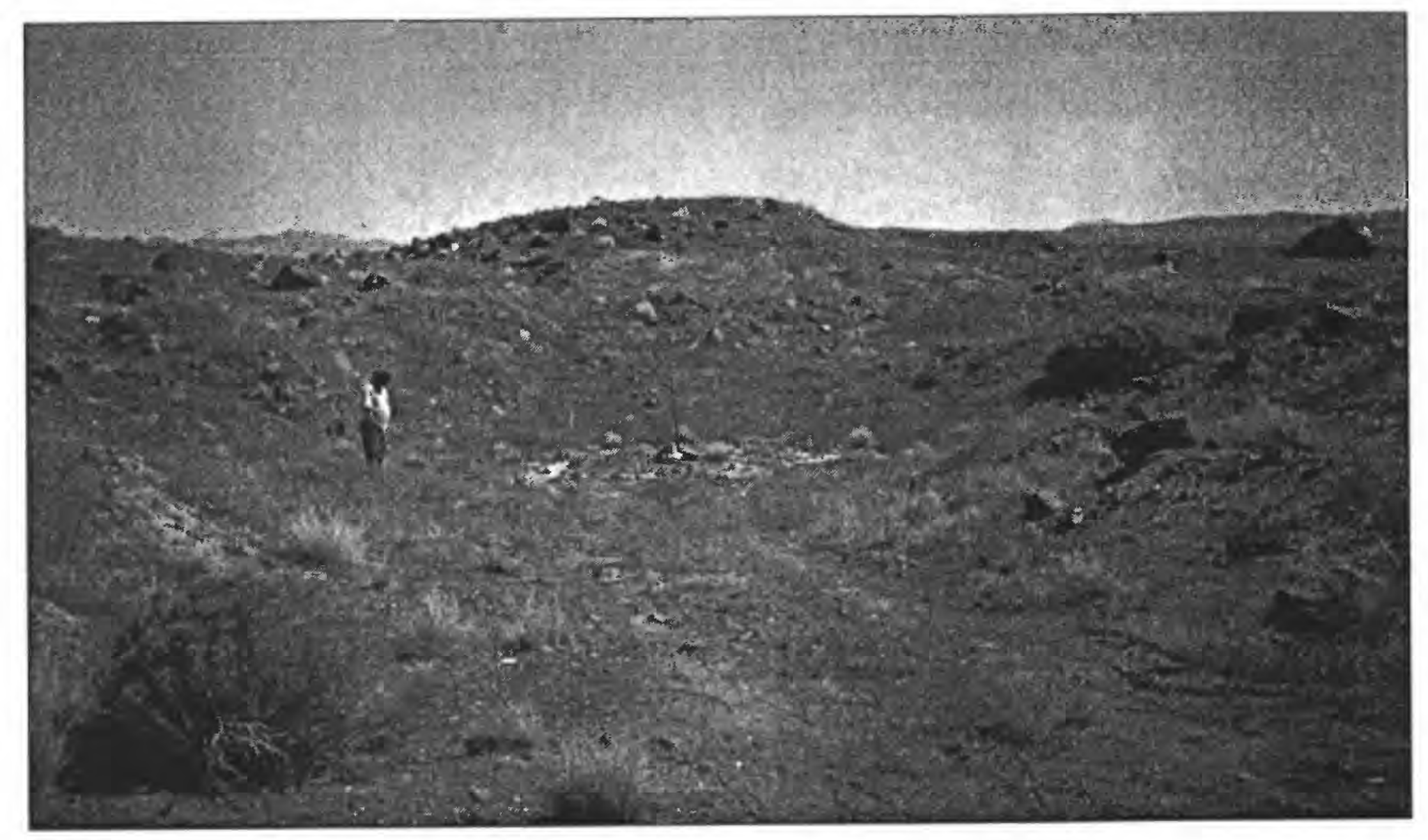

Figure 3. Photograph of well PM-2 in 1993. Photograph by G.L. Otto, U.S. Geological Survey.

Pahute Mesa is variable, primarily due to altitude, and ranges from 20.3 to $30.5 \mathrm{~cm}$ (Winograd and Thordarson, 1975 , p. C6).

\section{Geohydrologic Setting}

On NTS, surface-water runoff usually occurs during March and April following spring snowmelt, and during July and August following infrequent but intense thunderstorms. In the eastern areas of NTS, surface water flows into playas (dry lake beds) in Yucca and Frenchman Flats. In the northwest part of NTS near well PM-2 (Areas 19 and 20), water may run off beyond the NTS boundaries onto NAFR. The southern and western parts of NTS also may channel waters off site toward Death Valley.

The NTS is in a geohydrologically complex area where alluvium of Quaternary age overlies volcanic rock of Tertiary age and complexly fractured clastic and carbonate rocks of Paleozoic and Precambrian age. The geohydrologic system consists of a valley-fill aquifer, the volcanic tuffs and lava flows that include several aquifers and confining units, and the carbonate aquifer and clastic confining units. Perched zones are common throughout the NTS (Laczniak and others, 1996).

\section{Geology}

The NTS is in a structurally complex part of the southern Basin and Range physiographic province. The eastern part of Pahute Mesa (Areas 19 and 20) is part of the Southwest Nevada Volcanic Field. Well PM-2 is situated in a volcanic province of Tertiary age where ash-flow and ash-fall tuffs and rhyolitic lava flows more than 4,171 $\mathrm{m}$ thick were erupted from two calderas (fig. 2), the Area 20 and Grouse Canyon calderas, which together form the Silent Canyon caldera complex (Blankennagel and Weir, 1973, p. B3). Much of the area is covered by younger ash-flow and ash-fall tuff erupted from calderas to the south and west. Distribution of geologic units is extremely variable due to proximity to calderas, pre-depositional topography, and post-depositional faulting. The well penetrates a suite of volcanic rock - tuffs, rhyolites and lavas overlying porphyritic granodiorite (table 1).

\section{Ground Water}

Ground water beneath NTS is part of the Death Valley ground-water flow system, which consists of four subbasins: Oasis Valley, Ash Meadows, Alkali Flat-Furnace Creek Ranch, and Death Valley (fig. 1). Regional ground-water flow beneath NTS is in three 
subbasins - Oasis Valley and Ash Meadows subbasins in Nevada and the Alkali Flat-Furnace Creek Ranch subbasin in Nevada and California. Well PM-2 is within the Oasis Valley flow system. Depth to ground water may range from about $156 \mathrm{~m}$ below land surface in Frenchman Flat to more than $600 \mathrm{~m}$ below land surface on Pahute Mesa (Winograd and Thordarson, 1975, p. C47).

The water-level altitude throughout the volcanic sequences within the Silent Canyon caldera complex on Pahute Mesa is from $1,268 \mathrm{~m}$ to $1,428 \mathrm{~m}$ above sea level ( $594 \mathrm{~m}$ to $716 \mathrm{~m}$ below land surface), according to Blankennagel and Weir $(1973, \mathrm{pl}$. 1). Northwest of the caldera, near well PM-2, Blankennagel and Weir $(1973, \mathrm{pl} .1)$ indicate that the altitude of the water table is about $1,432 \mathrm{~m}$ ( $260 \mathrm{~m}$ below land surface). In Area 20 , thick layers of lower permeability ash-flow and ash-fall tuffs separate thinner and less extensive rhyolitic lava flows of higher permeability. Ground water moves primarily through interconnected fractures within the units. In general, zeolitized and nonwelded tuffs are less permeable and act as confining units, while the welded ash-flow tuffs and rhyoliticlava flows form aquifers (Blankennagel and Weir, 1973, p. B7). Water-level contours in eastern Pahute
Mesa are shown in figure 5 as reported by Blankennagel and Weir (1973, pl. 1). A recent water-level contour map by O'Hagan and Laczniak (1996) shows water levels in eastern Pahute Mesa that closely approximate those of Blankennagel and Weir (1973, pl. 1). Figure 5 indicates that well PM-2 lies upgradient from the Schooner event (assuming that ground-water flow is perpendicular to the contours shown on figure 5 and that ground water flows in the two dimensions shown on the map). A more thorough discussion on hydrogeologic units, ground-water occurrence, and groundwater flow is given by Laczniak and others (1996).

\section{The Schooner Event}

The only test in the immediate area of well PM-2 was the Schooner event (U-20u), detonated approximately 270 m southeast of well PM-2 (fig. 2). The next closest test was more than $4 \mathrm{~km}$ east-southeast of well PM-2. Schooner was a 30 -kiloton cratering demonstration in December 1968 detonated at a depth of $108.2 \mathrm{~m}$ (Henry, 1969, p. 1). The crater created by the Schooner event is about $129.8 \mathrm{~m}$ in radius and $63.4 \mathrm{~m}$ in depth. The continuous-ejecta limit (the outermost limit of continuous deposits of earth materials thrown out and away from the explosion) was asymmetrical

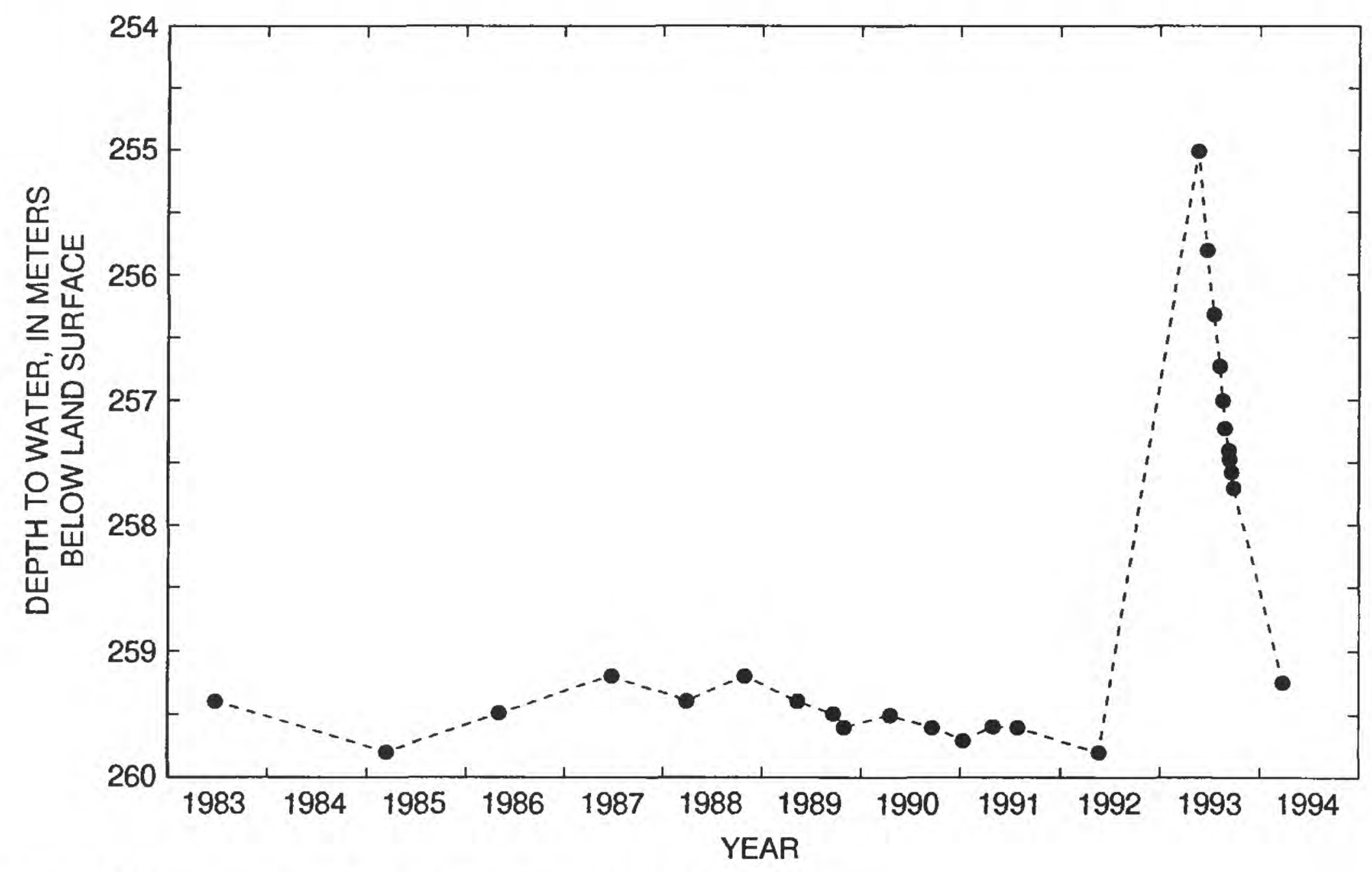

Figure 4. Measurements of depth to water in well PM-2, 1983-94. 

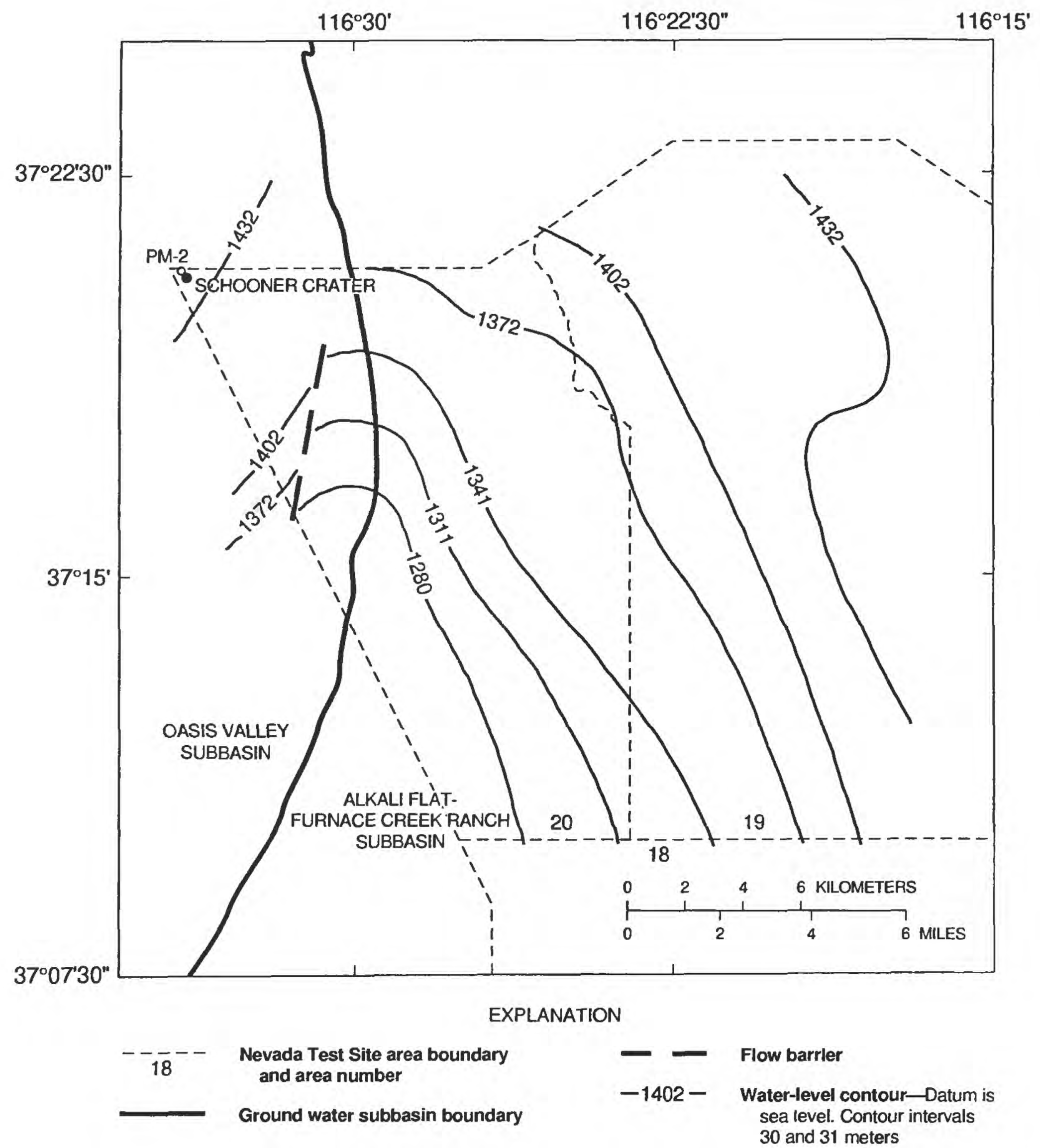

Figure 5. Water-level contours in eastern Pahute Mesa (modified from Blankennagel and Weir, 1973, where the contour interval is 100 feet).

(fig. 6), ranging from about $518 \mathrm{~m}$ to $823 \mathrm{~m}$. The maximum extent ejected earth materials could be mapped exceeded 1,830 m (Henny, 1969, p. 53). Well PM-2 was completed in 1964 and buried beneath approximately $3 \mathrm{~m}$ of ejecta from the Schooner event in 1968 . The crater and ejecta are shown in figure 6 , which is an aerial photograph taken in 1989 by EG\&G Energy Measurements, Inc. (EG\&G). Also evident on the photograph is the access road to Schooner and well PM-2, north and west of the crater, clearly within the ejecta pattern (L. Tinney, EG\&G, written commun., 1994). Additional information available from EG\&G concerning the Schooner event includes enhanced Landsat imagery.

LLNL has compiled the radiochemical sources for the Schooner event (G.J. Nimz, LLNL, written commun., 1994). Because Schooner was a cratering event, less-than-typical amounts of fission products 


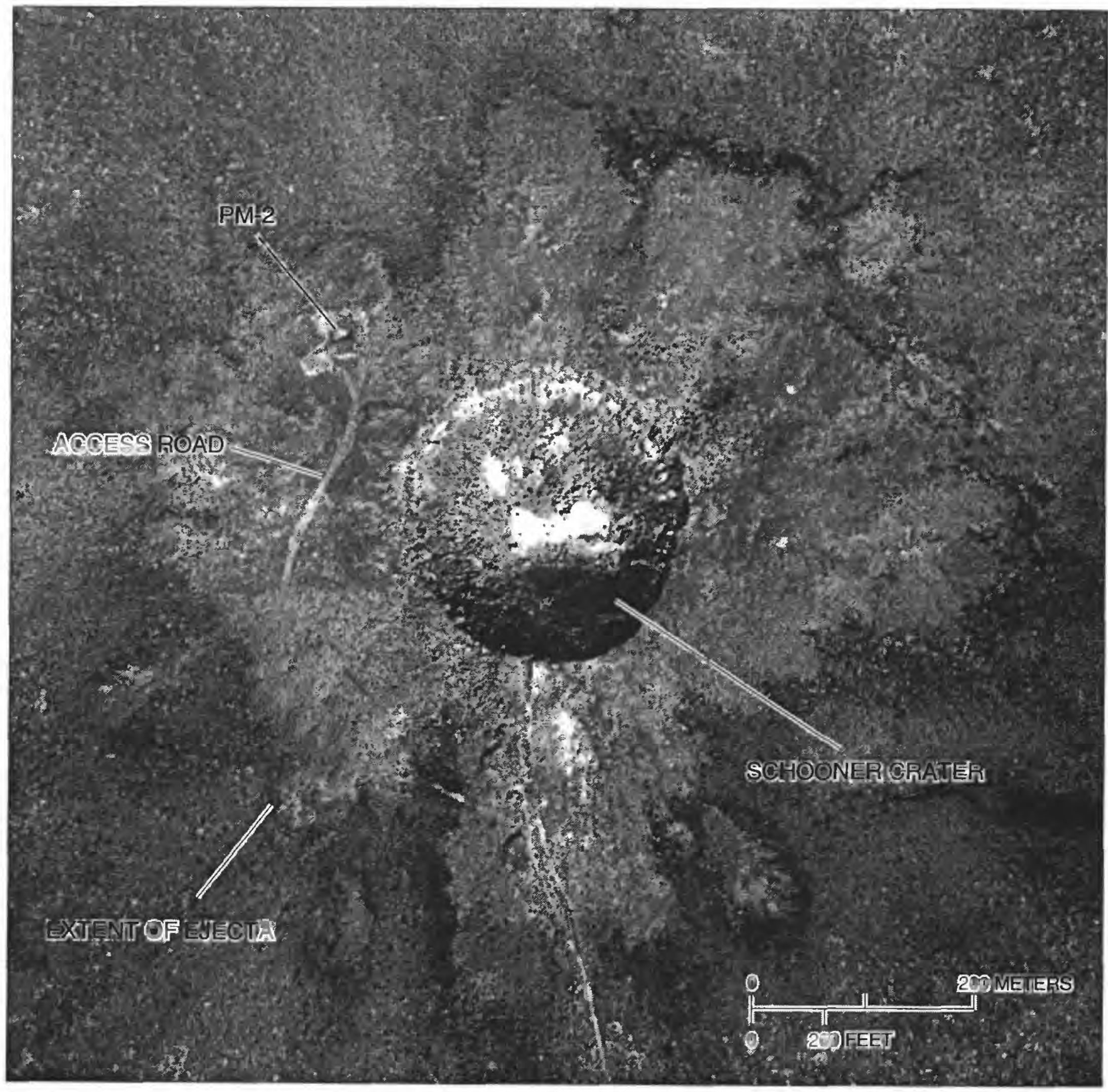

Figure 6. Aerial photograph of Schooner crater in 1989, showing extent of ejecta and location of well PM-2.

Photograph by EG\&G Energy Measurements, Inc.

were produced. At the same time, large amounts of activation products were produced in the surrounding soil and rock. A high ratio of activation products to fission products may help to identify Schooner as the source of contaminated water at well PM-2.

An aerial radiological survey of NTS and surrounding areas was made in 1970 and 1971 by EG\&G. The primary objective of the survey was to determine exposure-rate contours in selected areas in and around NTS. Background exposure rates in the Pahute Mesa area ranged from 20 to 25 microRoentgens per hour $(\mu \mathrm{R} / \mathrm{hr})$. Exposure rates exceeded $200 \mu \mathrm{R} / \mathrm{hr}$ in the
Schooner area. Background exposure rates north of NTS ranged from 20 to $30 \mu \mathrm{R} / \mathrm{hr}$. Exposure rates near the NTS boundary exceeded $200 \mu \mathrm{R} / \mathrm{hr}$ as a result of the nearby NTS cratering event (Schooner) and other testing (EG\&G Energy Measurements, Inc., 1972, p. 64).

An aerial radiological study was made in October 1992 to map possible contamination resulting from testing at NTS. The survey revealed a radioactive plume north of Schooner and on NAFR. The plume had a maximum anthropogenic gross count of 32,000 to 100,000 counts per second, of which 1,200 to 
2,600 counts per second are due to ${ }^{241} \mathrm{Am}$, a betadecay product of ${ }^{241} \mathrm{Pu} .{ }^{241} \mathrm{Am}$ count rate can be converted to surface activity, in units of becquerel per square meter $\left(\mathrm{Bq} / \mathrm{m}^{2}\right)$, and to average activity in the top $1 \mathrm{~cm}$, in units of becquerel per gram $(\mathrm{Bq} / \mathrm{g})$. The maximum anthropogenic count rate of 2,600 counts per second equates to a surface activity of $173.9 \mathrm{~Bq} / \mathrm{m}^{2}$ and an average activity in the top $1 \mathrm{~cm}$ of $11.8 \mathrm{~Bq} / \mathrm{g}$ (EG\&G Energy Measurements, Inc., 1992, p. 9).

The ${ }^{241} \mathrm{Am}$ activities of a material can be multiplied by the Pu-to-Am ratio of the material to obtain an estimate of $\mathrm{Pu}$ activity. For Schooner fallout, the $\mathrm{Pu}$-to-Am ratio is approximately 0.7 ; therefore, the maximum surface activity of $\mathrm{Pu}$ in the top $1 \mathrm{~cm}$ is 8.3 Bq/g (EG\&G Energy Measurements, Inc., 1992, p. 8).

\section{Previous Studies}

Several U.S. Geological Survey reports detail activities concerning well PM-2. The lithology of rocks penetrated by well PM-2 is discussed by Hasler and Byers (1965). Well history, drilling data, and hydraulic testing at well PM-2 are discussed by Blankennagel and others (1964) and Blankennagel and Weir (1966). Geologic data at satellite holes for Schooner are discussed by Purtymun and others (1969). Other reports (Thordarson and others, 1967; Orkild, 1969; Orkild and Jenkins, 1970) summarize activities and data the well PM-2 site. An Air Force report by Henny (1969) details observations concerning the Schooner event.

\section{Acknowledgments}

The authors thank the participating agencies associated with the U.S. Department of Energy HRMP: Lawrence Livermore National Laboratory, Los Alamos National Laboratory, Desert Research Institute, and Reynolds Electrical and Engineering Co. The authors express appreciation to Richard H. Pearl, Stephen H. Leedom, and Douglas W. Duncan of the U.S. Department of Energy for support during the compilation of the data. Special thanks to the HRMP members for the submission of materials for use in this report: Gregory J. Nimz, Lawrence Livermore National Laboratory, provided radionuclide and chemical analysis and radiochemical source terms for Schooner; Joseph L. Thompson, Los Alamos National Laboratory, provided water-quality-sampling data from well PM-2 and research into ejected materials at well PM-2; Paul R. Seaber and David Gillespie, Desert Research Institute, provided maps and assorted information; and Fred Ferate, Reynolds Electrical and Engineering Company, provided soil sample information and radionuclide and chemical analysis. Water-quality samples were analyzed by Terence M. Grady, Environmental Monitoring System Laboratory, U.S. Environmental Protection Agency, Las Vegas, Nev. Raytheon Services Nevada provided information on hole histories and geophysical logs. Larry Tinney, EG\&G Energy Measurements, Inc., provided maps, aerial photographs, and Landsat images of Pahute Mesa; and J.A. Zamudio, EG\&G, provided Landsat analysis.

\section{SUMMARY OF DATA ON WELL PM-2}

Summarized below are the construction and geophysical logging histories of well PM-2. Most of this information was obtained from records maintained by Raytheon Services Nevada (RSN). A report by Gillespie (1994) examined much of the available historical record on well PM-2 as part of the joint HRMP investigation into the radiological contamination of well PM-2. The summary description of the geologic and hydrologic properties of the units penetrated by well PM-2, as presented below, is from previously published reports. The soil chemistry around the wellhead and the water quality of samples from the well are characterized below from samples collected and analyzed as part of the joint HRMP investigation.

\section{Well Construction}

Well PM-2 was constructed between May 20 and October 13, 1964, and completed as an open-hole well with a vertical depth of $2,676.6 \mathrm{~m}$ below land surface. The well was cased to a depth of 1,675.7 m. Gun-type perforations in the casing were added in May 1966 at depths between 762.0 and $1,612.3 \mathrm{~m}$. Well-construction details of well PM-2 are shown in figure 7. Appendix A presents RSN hole-history data. The data include daily drilling activities, a hole-deviation survey, core sampling, and cementing records. The core samples obtained during drilling are archived at NTS in the USGS Core Library.

Well casings with outside diameters of $50.8 \mathrm{~cm}$, $34.0 \mathrm{~cm}$, and $24.4 \mathrm{~cm}$ were used in the construction of well PM-2 (fig. 7). All the casings were strung to land surface. The surface casing of 50.8-cm diameter was installed to a depth of $13.4 \mathrm{~m}$. The $34.0-\mathrm{cm}$ diameter casing was installed to a depth of $759.5 \mathrm{~m}$. The casing 


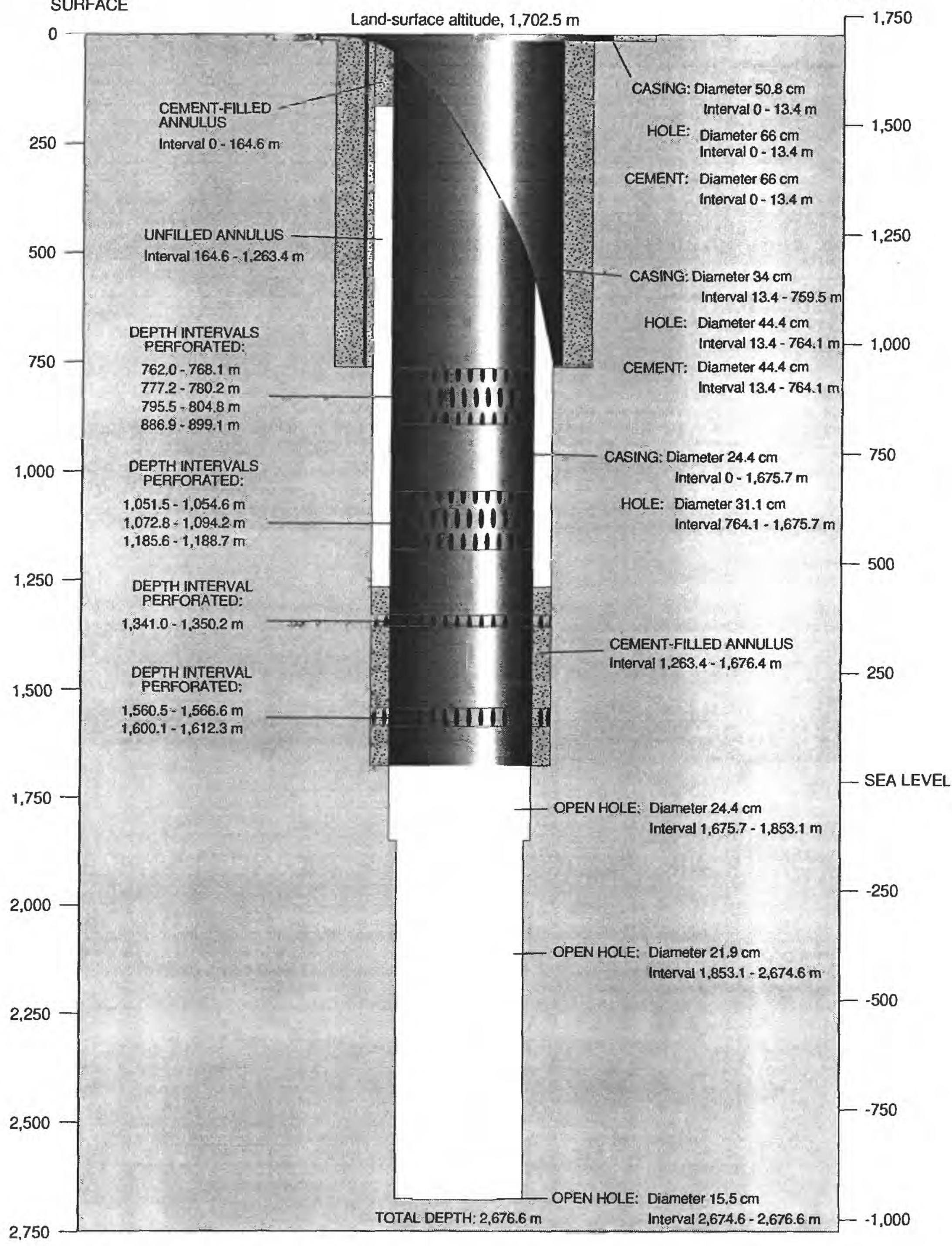

Figure 7. Construction details at well PM-2 from drillers' log. (Abbreviations: $\mathrm{cm}$, centimeter; $\mathrm{m}$, meter.) 
of 24.4-cm diameter was installed to a depth of 1,675.7 $\mathrm{m}$. Below the bottom of the 24.4-cm casing, from 1,675.7 to 2,676.6 m, well PM-2 was left as an open hole.

The annular spaces of the $50.8-\mathrm{cm}$ and the 34.0 $\mathrm{cm}$ casings were cemented throughout the length of their casings. The annular space of only the uppermost part and the lowermost part of the 24.4-cm diameter casing was cemented. The annular space of the 24.4$\mathrm{cm}$ casing was left open from $164.6 \mathrm{~m}$ to $1,263.4 \mathrm{~m}$.

Filling, bridging, and caving of the drill hole were the main problems during the construction of PM-2. These problems first began to slow the drilling at about $1,265 \mathrm{~m}$ and continued to cause delays until drilling reached a depth of about $1,965 \mathrm{~m}$. Of the 146 days the drill rig was at the site, 32 days were lost in washing and cleaning out bridges and fills in the hole and in attempts to prevent caving. One unsuccessful attempt involved setting packers between 1,664.2 m and 1,761.7 $\mathrm{m}$ and injecting 6,359.3 $\mathrm{L}$ of an "AM9" solution. AM-9 is an acrylamide, which polymerizes under the influence of ammonium persulfate and $\mathrm{K}$ ions (J.L. Thompson, LANL, written commun., 1994). However, replacing the circulation medium of the drill hole from an air-and-water mist to a bentonite-based mud mixed with diesel oil allowed drilling to continue from $1,965 \mathrm{~m}$ to the bottom of the hole at $2,676.6 \mathrm{~m}$. To prevent further caving after total depth was reached, the drilling mud was left in the hole.

\section{Log Characteristics}

RSN has about 70 geophysical logs on well PM-2. Information on the type of logs available, dates the logs were run, and the logged interval is presented in Appendix B. Most of the logs (43) were made during June-October 1964 as an aide in the drilling of well PM-2.

In April 1966, logs were run in preparation for the gun perforation of the well PM-2 casing. In November 1968, casing-collar-locator, caliper, and fluid-density logs were run prior to the December 1968 Schooner event. In June 1969, similar logs also were run to investigate the possible effect of the Schooner event on well PM-2. On June 20, 1983, a depth-check log was run and the USGS began periodic depth-to-water measurements in well PM-2. In October 1983, several geophysical logs were completed.

Caliper and casing collar locator logs made in November 1968 and in June 1969, before and after the Schooner event in December 1968, were compared by
Gillespie (1994). Both sets of logs were completed in the interval from 0 to $304.8 \mathrm{~m}$. Five possible breaks in the casing were identified at depths of $19.5,37.5,62.5$, 144 , and $151.5 \mathrm{~m}$.

On July 11, 1994, a video camera was lowered into well PM-2 by LLNL to examine the casing for breaks. The camera was slowly run from the surface to the water table, passed the depths identified as suspect from the logs. No ruptures or tears in the casing were found. The video log of the well showed no evidence that ground water could have entered the well bore above the water level through casing breaks.

\section{Geologic Characteristics}

Original lithology of well PM-2 is characterized by Hasler and Byers (1965). Geologic data for Schooner observation holes are discussed by Purtymun and others (1969). More recently, geologic nomenclature has been updated by Warren and others (1989). A summary of the geologic groups, units, lithologies, and depths at well PM-2 as described by Warren and others (1989) is in table 1. Results from cores that were analyzed immediately following drilling at well PM-2 show slightly welded tuffs down to $825.05 \mathrm{~m}$ with no fractures. Dacitic lavas and argillized lithic-rich tuffs between $874.8 \mathrm{~m}$ and $1,268 \mathrm{~m}$ were slightly to moderately fractured. The lava flows between $1,268 \mathrm{~m}$ and $2,520.7 \mathrm{~m}$ were moderately to highly fractured. The intrusive contact zone from $2,520.7 \mathrm{~m}$ to $2,554.1 \mathrm{~m}$ was moderately fractured whereas the granodiorite porphyry from $2,554.1 \mathrm{~m}$ to $2,676.8 \mathrm{~m}$ were extremely fractured (Hasler and Byers, 1965, p. 4).

\section{Soil Characteristics}

Soil samples around the wellhead of well PM-2 were obtained on November 19, 1993, by REECo's Ramatrol Division for analysis by REECo Analytical Services Division. Summary results of soil moisture, ${ }^{3} \mathrm{H}$, and gamma spectroscopy on the soil around the wellhead are shown in table 2. A copy of REECo's analytical report on the soil samples is provided in Appendix C. Locations of six soil-sampling points around well PM-2 and the field descriptions of each site are in figure 8 . Soil samples were obtained 5 or $5.6 \mathrm{~m}$ from the wellhead at the surface and from a depth of $30 \mathrm{~cm}$ at each site. Some of the samples represented undisturbed pre-event soil (virgin soil) and some samples represented ejecta from the Schooner event (throwout; F.D. Ferate, REECo Analytical Services, written 
Table 1. Summary of lithologic log of well PM-2 (modified by Warren and others, 1989; R.G. Warren, Los Alamos National Laboratory, written commun., 1991)

\begin{tabular}{|c|c|c|c|}
\hline \multirow{2}{*}{$\begin{array}{l}\text { Depth } \\
\text { (meters below } \\
\text { land surface) }\end{array}$} & \multicolumn{2}{|c|}{ Stratigraphic unit } & \multirow{2}{*}{ Lithology } \\
\hline & Group & Member & \\
\hline $0-15.2$ & Thirsty Canyon Group & Trail Ridge Tuff & Densely welded ash-flow tuff \\
\hline $15.2-91.4$ & do. & Pahute Mesa Tuff & Partially welded and nonwelded ash-flow tuff \\
\hline $91.4-109.7$ & do. & Rocket Wash Tuff & Densely welded ash-flow tuff \\
\hline $109.7-164.6$ & Belted Range Group & Grouse Canyon Tuff & Densely welded ash-flow tuff \\
\hline $164.6-298.7$ & Tunnel Formation & Tunnel 3 member: Beds3bc & $\begin{array}{l}\text { Bedded tuff: tuffaceous sandstone and interbedded } \\
\text { nonwelded ash-flow tuff }\end{array}$ \\
\hline $298.7-402.3$ & Volcanics of Big Dome & Tub Spring Tuff & Nonwelded ash-flow tuff \\
\hline $402.3-451.1$ & Older volcanics & Rhyolite of Quartz Mountain & Zeolitized-bedded tuff \\
\hline $451.1-719.3$ & do. & Redrock Valley Tuff & Zeolitized nonwelded tuff \\
\hline $719.3-755.9$ & do. & $\begin{array}{l}\text { Volcanics of Mount Helen: } \\
\text { dacite-andesite }\end{array}$ & Dacite-andesite \\
\hline $755.9-874.8$ & do. & Upper "Fraction" Tuff & Zeoltized nonwelded tuff \\
\hline $874.8-1,033.3$ & do. & $\begin{array}{l}\text { Volcanics of Mount Helen: } \\
\text { dacite-andesite }\end{array}$ & Dacitic flow breccias and lava \\
\hline $1,033.3-1,268.0$ & do. & $\begin{array}{l}\text { Volcanics of Mount Helen: } \\
\text { Tuff of Wilsons Camp }\end{array}$ & $\begin{array}{l}\text { Nonwelded zeolitized lithic tuffs, dacitic lava and } \\
\text { flow breccias; zeolitized lithic nonwelded tuff; } \\
\text { bedded tuffaceous mudstone }\end{array}$ \\
\hline $1,268.0-2,554.1$ & do. & $\begin{array}{l}\text { Volcanics of Mount Helen: } \\
\text { dacite-andesite }\end{array}$ & $\begin{array}{l}\text { Dacitic lava flows; bedded tuff (zeolitized tuffaceous } \\
\text { sandstone and mudstone); rhyodacitic lava flows; } \\
\text { zeolitized nonwelded tuff; altered dacitic lava } \\
\text { flow; silicified volcanic rock near basal contact }\end{array}$ \\
\hline $2,554.1-2,633.3$ & Brecciated aplite and granodiorite & & \\
\hline $2,633.3-2,676.8$ & Granodiorite & & \\
\hline
\end{tabular}

commun., 1994). The soil around the wellhead was moved and graded after the Schooner test to uncover the well and to re-establish a dirt road to the well. As a result of these activities, the soil samples probably are a mix of undisturbed soil and ejecta material (F.D. Ferate, REECo Analytical Services, written commun., 1994).

Soil moisture was analyzed by measuring the mass of water in $10 \mathrm{~g}$ of each soil sample to determine the relation of the ${ }^{3} \mathrm{H}$ concentrations in the soil to ${ }^{3} \mathrm{H}$ concentrations in water (Appendix C). The ${ }^{3} \mathrm{H}$ concentration of the soil was determined by multiplying the ${ }^{3} \mathrm{H}$ concentration of the extracted water by the ratio of the soil-moisture mass to soil mass (F.D. Ferate, REECo, written commun., 1994).

Soil moistures ranged from 0.11 to $0.58 \mathrm{~g}$ of water per $10 \mathrm{~g}$ of soil, except for the sample at point $\mathrm{C}$ at $30 \mathrm{~cm}$. The soil moisture of this sample was $2.5 \mathrm{~g}$ of water per $10 \mathrm{~g}$ of soil. The field description of this sample indicates that the sample was from the middle of the road leading to well PM-2 and that a layer of caliche was directly above the sample. The sample has a different physical appearance than all other samples. It is a fine, whitish, chalky-looking powder of low density and may be a powdered caliche (F.D. Ferate, REECo, written commun., 1994).

In general, results of ${ }^{3} \mathrm{H}$ analysis indicated a higher level of ${ }^{3} \mathrm{H}$ activity at a depth of $30 \mathrm{~cm}$ than samples from the surface (table 2). ${ }^{3} \mathrm{H}$ activity in the soil moisture ranged from $1,038 \mathrm{~Bq} / \mathrm{L}$ to $33,105 \mathrm{~Bq} / \mathrm{L}$. Water samples from depth at well PM-2 had similar values. ${ }^{3} \mathrm{H}$ activities in the soil ranged from 0.019 to $1.62 \mathrm{~Bq} / \mathrm{g}$ soil (table 2 ).

Gamma spectroscopy also was done on the samples by REECo Analytical Services for the detection of radionuclides and results are in Appendix C. Samples were normalized to weight and placed on the end of a high-purity $\mathrm{Ge}$ detector in a $500-\mathrm{mL}$ bottle and counted for 20 minutes. Detection limits are from 0.004 to $0.001 \mathrm{~Bq} / \mathrm{g}$. Gamma spectroscopy of the soil samples identified six nonnaturally occurring radionuclides $\left({ }^{241} \mathrm{Am},{ }^{60} \mathrm{Co},{ }^{137} \mathrm{Cs},{ }^{150} \mathrm{Eu}{ }^{152} \mathrm{Eu},{ }^{154} \mathrm{Eu}\right)$ and four naturally occurring radionuclides $\left({ }^{40} \mathrm{Kr},{ }^{226} \mathrm{Ra}\right.$, ${ }^{228} \mathrm{Th},{ }^{232} \mathrm{Th}$ ). The gamma spectrum of each soil sample had numerous unidentified peaks with high counting errors (Appendix C). 


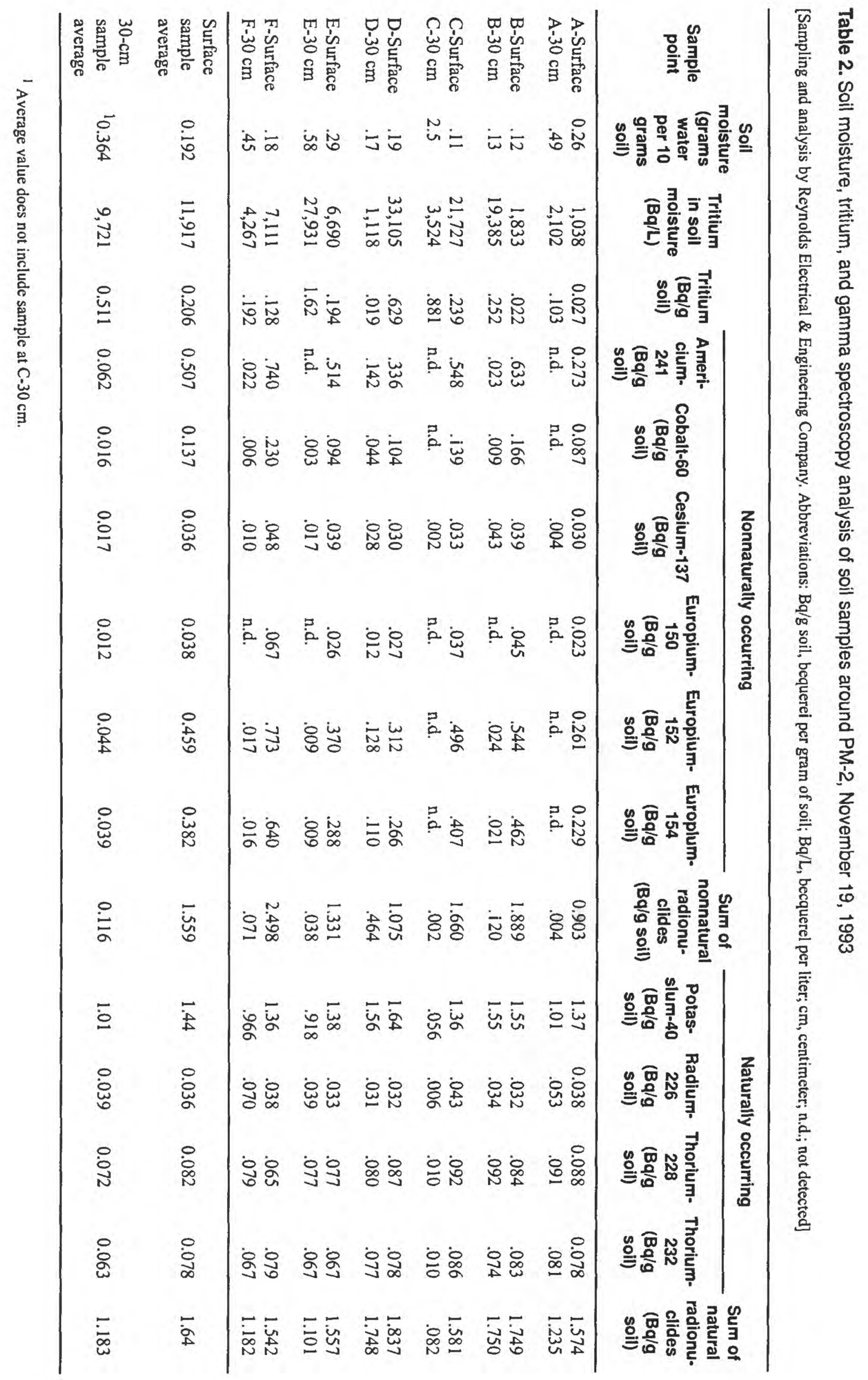




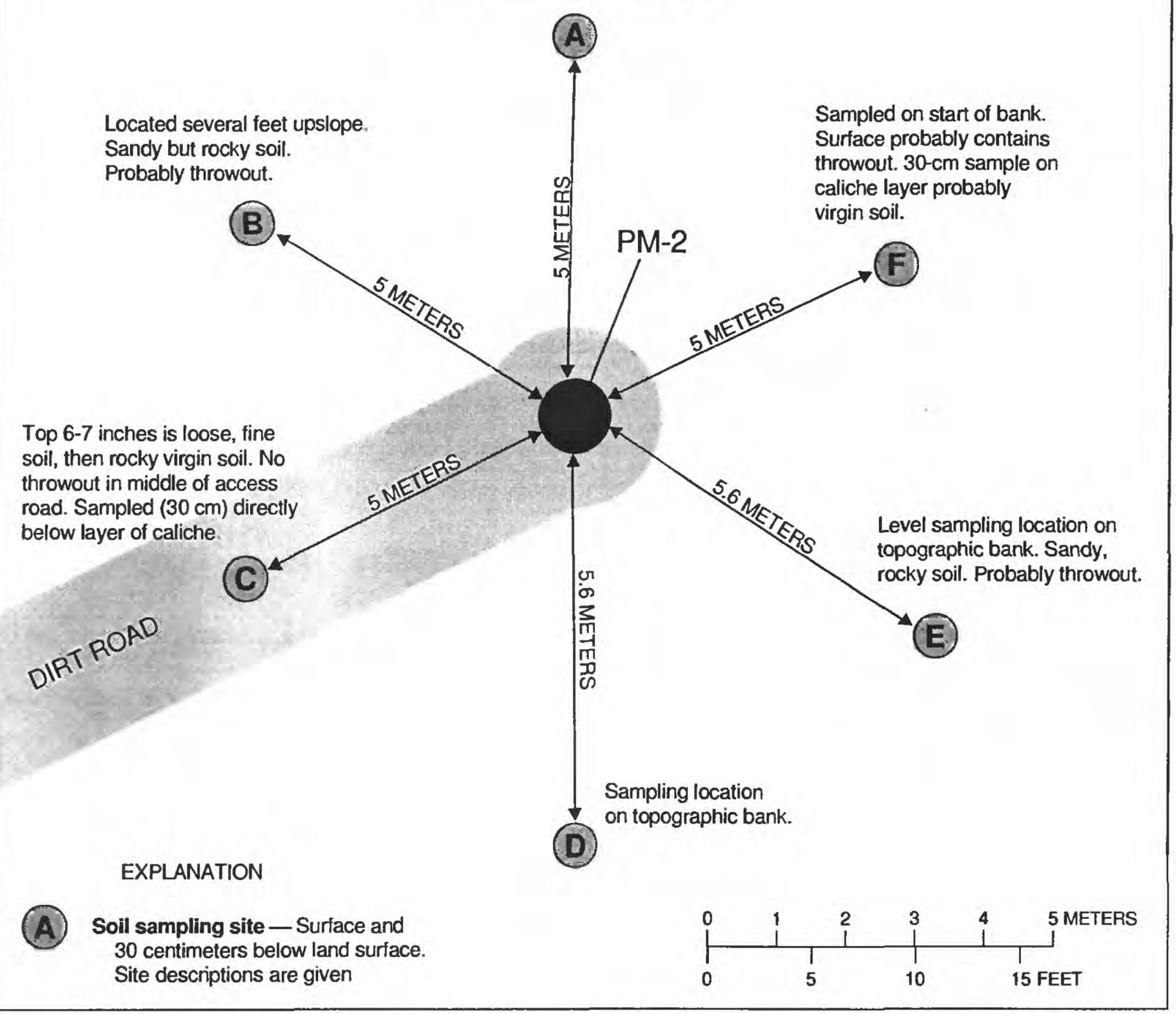

Figure 8. Soil-sampling sites adjacent to well PM-2 (from REECo field notes).

Results from previous soil-profile studies at other NTS areas showed that generally more than 95 percent of Am remained in the top $5 \mathrm{~cm}$ of surface soil after 10 20 years of residence time in undisturbed areas (Romney and others, 1987). At each of the six soil-sample sites near well PM-2, ${ }^{241}$ Am concentration was greater in soil collected from the surface than from $30 \mathrm{~cm}$ (table 2). ${ }^{241} \mathrm{Am}$ was not detected in three of the soil samples at $30 \mathrm{~cm}$, while the ratio of ${ }^{241} \mathrm{Am}$ at surface to ${ }^{241} \mathrm{Am}$ at $30 \mathrm{~cm}$ in the other three samples ranged from 2.36 to 33.6 .

Activities of the six nonnaturally occurring radionuclides in the 12 soil samples ranged from not detected to $0.773 \mathrm{~Bq} / \mathrm{g}$ of soil (table 2). The sum of the radioactivity of these six radionuclides at a given site ranged from 0.002 to $2.498 \mathrm{~Bq} / \mathrm{g}$ of soil. At each of the six sites, the total activity of the surface samples was at least an order of magnitude greater than samples at $30 \mathrm{~cm}$. At sample $A$ at $30 \mathrm{~cm}$ and sample $C$ at $30 \mathrm{~cm}$, only trace amounts of ${ }^{137} \mathrm{Cs}$ were found.

The four naturally occurring radionuclides were found in all 12 samples, ranging in value from 0.006 to $1.64 \mathrm{~Bq} / \mathrm{g}$ of soil (table 2). The total activity of these four radionuclides at a given site ranged from 0.082 to $1.837 \mathrm{~Bq} / \mathrm{g}$ of soil. The radionuclides were nearly equally distributed between the surface samples and samples at $30 \mathrm{~cm}$ for a given site, except at site $C$. The surface sample at site $\mathrm{C}$ had more than an order of 
magnitude greater activity of natural radionuclides than the $30-\mathrm{cm}$ sample. This is consistent with the interpretation that this sample is caliche (F.D. Ferate, REECo Analytical Services, written commun., 1994).

Relative to underground tests, cratering events, such as Schooner, typically produce more neutronactivation products than fission products. Of the six nonnaturally occurring isotopes, four are activation products $\left({ }^{60} \mathrm{Co},{ }^{150} \mathrm{Eu},{ }^{152} \mathrm{Eu},{ }^{154} \mathrm{Eu}\right)$ and only ${ }^{137} \mathrm{Cs}$ is a fission product. ${ }^{241} \mathrm{Am}$ is a decay product of ${ }^{241} \mathrm{Pu}$, a common nuclear fuel (G.J. Nimz, LLNL, written commun., 1994).

\section{Hydrologic Characteristics}

Hydraulic testing at well PM-2 in July 1964 is summarized in Appendix D. A detailed account of hydrologic testing at well PM-2 is given by Blankennagel and others (1964). Typically, hydraulic testing consisted of a suite of geophysical logs being run, followed by pumping tests, then a series of injection or swabbing tests. Injection tests indicated a low relative specific capacity for water flow. A swabbing test was run with the hole open from $759.5 \mathrm{~m}$ to $1,214.0 \mathrm{~m}$ (Blankennagel and others, 1964, p. 24). The water level was lowered $274.3 \mathrm{~m}$ below the static water level of approximately $394.4 \mathrm{~m}$ with little indication of water inflow. Recovery over the next $17 \frac{1}{2}$ hours was $13.7 \mathrm{~m}$.

Water-level measurements have been sporadic over the years and are available during drilling, testing, and logging activities at well PM-2. In 1969, waterlevel measurements were discontinued following the Schooner event, until 1983, when the U.S. Geological Survey began measurements on an intermittent basis (table 3). The water level had remained almost constant from 1983 through 1993 varying less than $0.65 \mathrm{~m}$. In May 1993, a water-level measurement indicated that levels in the well had risen $4.77 \mathrm{~m}$ (fig. 4). Subsequent measurements show water levels declining to previous levels.

\section{Water-Quality Analyses}

Water samples from the deep wells and holes at NTS are routinely collected with a wireline point sampler. The stainless-steel sampler is about $1.52 \mathrm{~m}$ long and $4.1 \mathrm{~cm}$ in diameter, and has a capacity of $2.2 \mathrm{~L}$. The sample intake ports are about $1 \mathrm{~m}$ below a water-level sensor attached to the sampler. The ports are closed while the device is lowered and raised in the water column and are opened when the desired depth is reached. Prior to collecting a water sample, the standard U.S. Geological Survey procedure is to rinse the sampler with a 0.5 percent solution of hydrochloric acid, followed by rinsing with distilled water. Problems associated with collecting water samples with a point sampler include concerns about the representativeness of a sample of water from inside the casing to that of water in the aquifer; time delay in bringing a water sample to the surface; and mixing of the water column caused by lowering and raising the sampler.

\section{Field Water Quality, Tritium, and Krypton}

Four water samples were collected on August 17, 1993, from well PM-2 as part of an investigation of the unexpected rise in the water level. Samples were collected with a point sampler at $258 \mathrm{~m}$ (water surface), $305 \mathrm{~m}, 610 \mathrm{~m}$, and $765 \mathrm{~m}$ below land surface. The first open interval in the well casing is between 762 and 768 $\mathrm{m}$. After the samples were brought up from depth, the temperature, specific conductance, and $\mathrm{pH}$ were determined in the field as soon as possible. ${ }^{3} \mathrm{H}$ analysis were done later in the laboratory by the EMSL. No ${ }^{3} \mathrm{H}$ analysis from well PM-2 prior to 1993 could be located. Field water-quality and ${ }^{3} \mathrm{H}$-analysis results are shown in figure $9 .{ }^{3} \mathrm{H}$ levels in the two deepest samples $(20,400 \mathrm{~Bq} / \mathrm{L}$ at $610 \mathrm{~m}$ and $23,500 \mathrm{~Bq} / \mathrm{L}$ at $765 \mathrm{~m})$ exceeded proposed USEPA limits for ${ }^{3} \mathrm{H}$ of $740 \mathrm{~Bq} / \mathrm{L}$ by almost two orders of magnitude. Four additional samples at depths below land surface of $305 \mathrm{~m}, 610 \mathrm{~m}$, $765 \mathrm{~m}$, and $1,067 \mathrm{~m}$ were obtained from well PM-2 on September 27, 1993 (fig. 9), to confirm the elevated ${ }^{3} \mathrm{H}$ levels.

Table 3. Summary of water-level measurements at well PM-2, 1983-94

\begin{tabular}{cccc}
\hline Date & $\begin{array}{c}\text { Water level } \\
\text { (meters below } \\
\text { land surface) }\end{array}$ & Date & $\begin{array}{c}\text { Water level } \\
\text { (meters below } \\
\text { land surface) }\end{array}$ \\
\hline $06-20-83$ & 259.38 & $09-30-91$ & 259.67 \\
$03-13-85$ & 259.85 & $05-20-92$ & 259.74 \\
$05-01-86$ & 259.53 & $05-20-93$ & 254.97 \\
$06-16-87$ & 259.20 & $06-18-93$ & 255.86 \\
$03-13-88$ & 259.44 & $07-12-93$ & 256.30 \\
$10-17-88$ & 259.22 & $08-02-93$ & 256.72 \\
$05-09-89$ & 259.43 & $08-17-93$ & 257.01 \\
$09-20-89$ & 259.50 & $08-24-93$ & 257.22 \\
$10-27-89$ & 259.56 & $09-07-93$ & 257.41 \\
$04-11-90$ & 259.48 & $09-14-93$ & 257.47 \\
$09-13-90$ & 259.59 & $09-23-93$ & 257.58 \\
$01-15-91$ & 259.68 & $09-27-93$ & 257.70 \\
$04-24-91$ & 259.56 & $03-28-94$ & 259.24 \\
$07-25-91$ & 259.61 & & \\
\hline
\end{tabular}



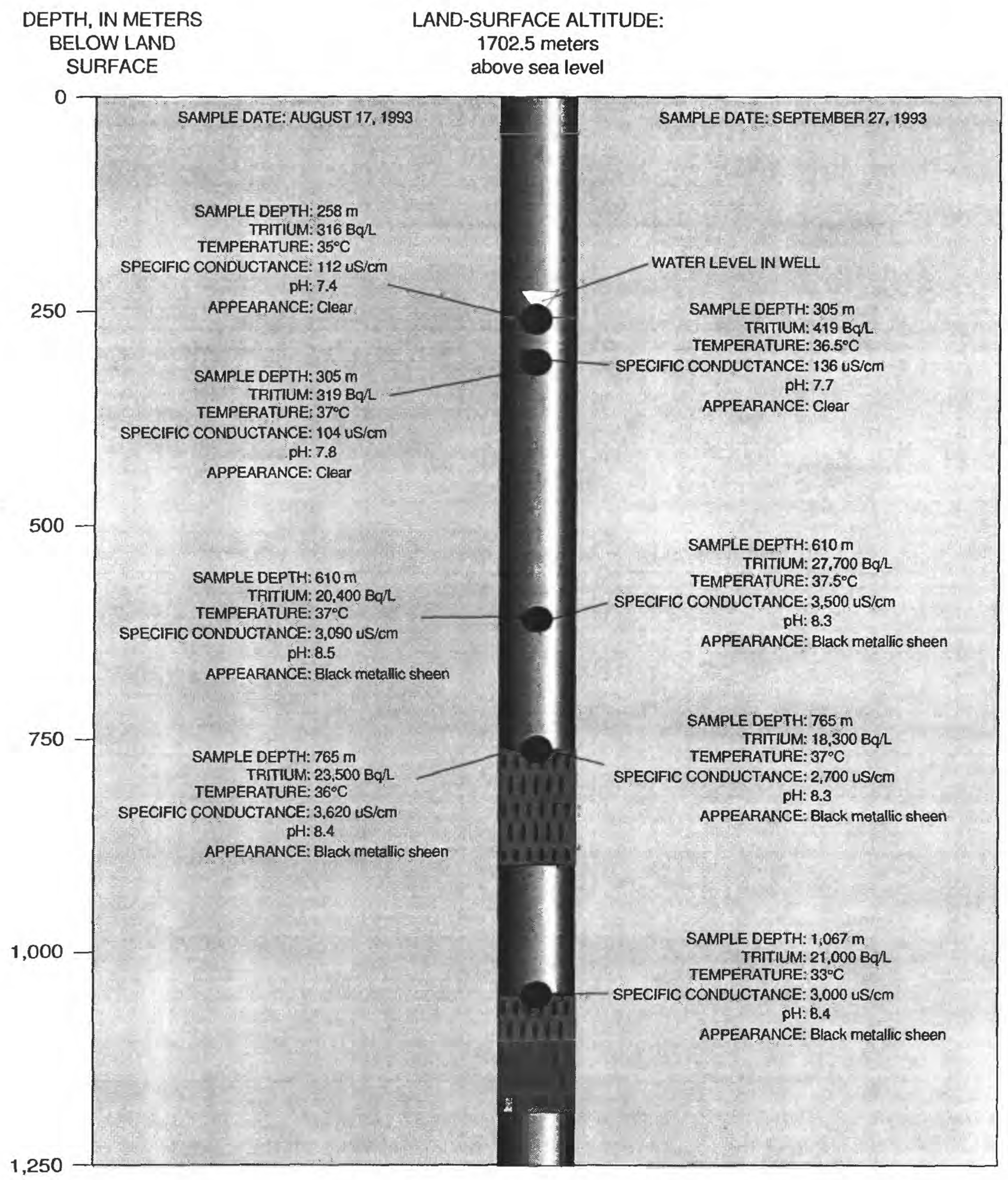

Figure 9. Water-quality data collected (by U.S. Geological Survey) at well PM-2, August 17, 1993, and September 27, 1993. Abbreviations: $\mathrm{Bq} / \mathrm{L}$, becquerel per liter; ${ }^{\circ} \mathrm{C}$, degree Celsius; $\mathrm{m}$, meter; $\mu \mathrm{S} / \mathrm{cm}$, microsiemens per centimeter. 
The water samples from $258 \mathrm{~m}$ and $305 \mathrm{~m}$ were generally clear, while the deeper samples were black in color with a somewhat metallic sheen. These deeper samples also rapidly effervesced when poured out of the sampler, which could affect the laboratory and field measurements if the samples were changing chemically to a new equilibrium. The $\mathrm{pH}$, specific conductance, and ${ }^{3} \mathrm{H}$ activity of the water samples at a depth of $610 \mathrm{~m}$ and below were about an order of magnitude greater than that of the samples at depths of $258 \mathrm{~m}$ and $305 \mathrm{~m}$ (fig. 9). The low specific conductance of these shallower samples (fig. 9) suggests that these waters could be classified as fresh (dissolved-solids concentration less than $1,000 \mathrm{mg} / \mathrm{L}$ ). The ${ }^{3} \mathrm{H}$ activity of the samples at $258 \mathrm{~m}$ and $305 \mathrm{~m}$ (table 4) was almost an order of magnitude less than the activity of the soilmoisture samples (table 2) taken around well PM-2.

The confirmation of the elevated ${ }^{3} \mathrm{H}$ levels in the well led to additional sampling by LLNL and LANL during November 30-December 1, 1993, and May 3-4, 1994. Samples were collected using point samplers stacked in tandem. The samplers were rinsed with deionized water, then alcohol, and evacuated prior to being lowered into the hole. Samples were split between LANL, LLNL, REECo, and the State of Nevada (G.J. Nimz, LLNL, written commun., 1994). LANL analyzed the sample in detail (which required a large volume of sample water) for ${ }^{3} \mathrm{H},{ }^{85} \mathrm{Kr}$, and gamma spectroscopy. LLNL was tasked with analysis for dissolved inorganic constituents, trace metals, volatile and semivolatile organic compounds, gross alpha and beta, and various radionuclides $\left({ }^{14} \mathrm{C},{ }^{36} \mathrm{Cl},{ }^{3} \mathrm{He}\right.$, ${ }^{4} \mathrm{He},{ }^{238} \mathrm{Pu},{ }^{239} \mathrm{Pu},{ }^{90} \mathrm{Sr}$ ) in addition to ${ }^{3} \mathrm{H}$ analysis and gamma spectroscopy.

${ }^{3} \mathrm{H}$ analyses from LANL (J.L. Thompson, LANL, written commun., 1994) and LLNL (G.J. Nimz, LLNL, written commun., 1994) are shown in table 4, along with results from previous analyses by EMSL (T.M. Grady, EMSL, written commun., 1993) and REECo (F.D. Ferate, REECo, written commun., 1994). The ${ }^{3} \mathrm{H}$ activity in water samples taken from $305 \mathrm{~m}$ and above was about two orders of magnitude less than water samples taken from $610 \mathrm{~m}$ and below. The average activity of ${ }^{3} \mathrm{H}$ from water samples from $258 \mathrm{~m}$ and $305 \mathrm{~m}$ was $515 \mathrm{~Bq} / \mathrm{L}$. The average activity of ${ }^{3} \mathrm{H}$ from $610 \mathrm{~m}$ and greater depths was $23,200 \mathrm{~Bq} / \mathrm{L}$. The variability of the ${ }^{3} \mathrm{H}$ analyses for a given depth may be due to movement into or out of the well or more likely a function of the mixing of the water column within the borehole as the sampling devices were lowered and raised. The highest ${ }^{3} \mathrm{H}$ values appear at $610 \mathrm{~m}$, which is about $155 \mathrm{~m}$ above the first known open interval in the well. Further investigation might clarify whether contamination entered the casing about $600 \mathrm{~m}$ below land surface. These ${ }^{3} \mathrm{H}$ values, however, were only slightly higher than values found at greater depth in the well (table 4).

Table 4. Tritium analysis of water samples from PM-2, 1993-94

[Tritium values in becquerels per liter. Abbreviations: EMSL, U.S. Environmental Protection Agency, Environmental Monitoring Systems Laboratory; REECo, Reynolds Electrical Electrical \& Engineering Co., Inc., Analytical Services; F.D., field data; L.D., laboratory data; LANL, Los Alamos National Laboratory; LLNL, Lawrence Livermore National Laboratory; n.d., not detected; n.m., not measured; n.s., not sampled]

\begin{tabular}{|c|c|c|c|c|c|c|c|c|}
\hline \multirow{2}{*}{$\begin{array}{l}\text { Analyzing } \\
\text { laboratory }\end{array}$} & \multirow{2}{*}{$\begin{array}{l}\text { Date(s) } \\
\text { sampled }\end{array}$} & \multicolumn{7}{|c|}{ Sample depth, below land surface } \\
\hline & & $\begin{array}{c}258 \\
\text { meters }\end{array}$ & $\begin{array}{c}305 \\
\text { meters }\end{array}$ & $\begin{array}{c}610 \\
\text { meters }\end{array}$ & $\begin{array}{c}765 \\
\text { meters }\end{array}$ & $\begin{array}{c}823 \\
\text { meters }\end{array}$ & $\begin{array}{c}915 \\
\text { meters }\end{array}$ & $\begin{array}{c}1,067 \\
\text { meters }\end{array}$ \\
\hline EMSL & $08 / 17 / 93$ & 316 & 319 & 20,400 & 23,500 & n.s. & n.s. & n.s. \\
\hline REECo & $08 / 17 / 93$ & 331 & 293 & 20,700 & 23,900 & n.s. & n.s. & n.s. \\
\hline EMSL & $09 / 27 / 93$ & n.s. & 419 & 27,700 & 18,300 & n.s. & n.s. & $I_{21,000}$ \\
\hline REECo & $09 / 27 / 93$ & n.s. & 445 & 29,600 & 19,500 & n.s. & n.s. & ${ }^{\prime} 22,300$ \\
\hline LLNL - F.D. & $11 / 30-12 / 01 / 93$ & n.s. & 537 & 27,200 & n.s. & 22,000 & 19,600 & n.s. \\
\hline LLNL - L.D. & $11 / 30-12 / 01 / 93$ & n.s. & 937 & 26,300 & n.s. & 22,900 & 21,400 & n.s. \\
\hline LANL & $11 / 30-12 / 01 / 93$ & n.s. & 541 & 27,000 & n.s. & 25,700 & n.s. & n.s. \\
\hline LLNL - F.D. & $05 / 3-4 / 94$ & n.s. & n.d. & n.s. & n.s. & 20,900 & n.m. & n.s. \\
\hline LLNL - L.D. & $05 / 3-4 / 94$ & n.s. & 756 & n.s. & n.s. & 24,600 & 21,600 & n.s. \\
\hline LANL & $05 / 3-4 / 94$ & n.s. & 770 & n.s. & n.s. & 25,100 & 23,300 & n.s. \\
\hline \multicolumn{2}{|c|}{ AVERAGE CONCENTRATION } & 324 & 557 & 25,600 & 21,300 & 23,500 & 21,500 & 21,600 \\
\hline
\end{tabular}

\footnotetext{
${ }^{1}$ Possible obstruction at 1,000 meters; depth may be less than 1,067 meters.
} 
${ }^{85} \mathrm{Kr}$ is a fission product of nuclear testing. Results of analyses by LANL for ${ }^{85} \mathrm{Kr}$ (J.L. Thompson, LANL, written commun., 1994) are given in table 5. The detection limit of the procedure used for ${ }^{85} \mathrm{Kr}$ analysis is $0.037 \mathrm{~Bq} / \mathrm{L} .{ }^{85} \mathrm{Kr}$ activity was low in all samples. ${ }^{85} \mathrm{Kr}$ was below the detection limit in samples from depths of $610 \mathrm{~m}$ and $823 \mathrm{~m}$ and only slightly above the limit in a sample from $915 \mathrm{~m}$. The highest activity was found in the sample from $305 \mathrm{~m}$, although the second time a sample was taken from this depth the value was just above the detection limit.

Table 5. Krypton-85 analysis of water samples from well PM-2, 1993-94

[Sampling and analysis by Los Alamos National Laboratory. Abbreviations: b.d.1., below detection limit; $\mathrm{Bq} / \mathrm{L}$, becquerels per liter; n.s., not sampled]

\begin{tabular}{lcccc}
\hline \multirow{2}{*}{$\begin{array}{c}\text { Dates } \\
\text { sampled }\end{array}$} & \multicolumn{4}{c}{ Sample depth, below land surface } \\
\cline { 2 - 5 } & $\begin{array}{c}\mathbf{3 0 5} \\
\text { meters }\end{array}$ & $\begin{array}{c}610 \\
\text { meters }\end{array}$ & $\begin{array}{c}\mathbf{8 2 3} \\
\text { meters }\end{array}$ & $\begin{array}{c}915 \\
\text { meters }\end{array}$ \\
\hline $11 / 30 / 93-$ & $0.52 \mathrm{~Bq} / \mathrm{L}$ & b.d.l. & b.d.l. & n.s. \\
$12 / 01 / 93$ & & & & \\
$05 / 03 / 94-$ & $0.09 \pm$ & n.s. & b.d.l. & $0.09 \pm$ \\
$05 / 04 / 94$ & $0.04 \mathrm{~Bq} / \mathrm{L}$ & & & $0.03 \mathrm{~Bq} / \mathrm{L}$ \\
\hline
\end{tabular}

\section{Carbon-14, Chlorine-36, and Strontium-90}

Results of analysis by LLNL for ${ }^{14} \mathrm{C},{ }^{36} \mathrm{Cl}$ (both of which are activation products) and ${ }^{90} \mathrm{Sr}$ (a fission product) on water samples collected November 30December 1,1993 , are presented in table $6 .{ }^{14} \mathrm{C}$ and ${ }^{36} \mathrm{Cl}$ were within expected activity levels. All ${ }^{90} \mathrm{Sr}$ samples were below detectable levels.

Table 6. Analysis of carbon-14, chloride-36, and strontium-90 in water samples from well PM-2, November 29-December 1, 1993

[Sampling and analysis by Lawrence Livermore National Laboratory. Abbreviations: b.d.l., below detection limit; $\mathrm{Bq} / \mathrm{L}$, becquerels per liter; n.s., not sampled]

\begin{tabular}{cccc}
\hline $\begin{array}{c}\text { Sample depth } \\
\text { (meters below } \\
\text { land surface }\end{array}$ & $\begin{array}{c}\text { Carbon-14 } \\
(\mathrm{Bq} / \mathrm{L})\end{array}$ & $\begin{array}{c}\text { Chloride-36 } \\
(\mathrm{Bq} / \mathrm{L})\end{array}$ & $\begin{array}{c}\text { Strontium-90 } \\
(\mathrm{Bq} / \mathrm{L})\end{array}$ \\
\hline 305 & 250 & 0.000152 & b.d.l. \\
610 & 200 & 0.0000222 & b.d.l. \\
823 & 100 & n.s. & b.d.l. \\
915 & 1,630 & 0.00002 & b.d.l. \\
\hline
\end{tabular}

\section{Helium Age Dating}

LLNL analyzed water samples collected at 610 and $910 \mathrm{~m}$ on November 29-December 1, 1993, for ${ }^{3} \mathrm{He}$ and ${ }^{4} \mathrm{He}$. The results of the analyses are presented in table 7. ${ }^{3} \mathrm{H}$ decays to $\mathrm{He}$, and this ratio can be used as a dating tool. Analysis of the data by LLNL suggest that the water samples were about 9 years old. Limitations of the analysis include loss of $\mathrm{He}$ to the atmosphere, especially if the aquifer is not totally confined, contact of the sample with air during sampling, or mixing of waters with different $\mathrm{He}$ ratios.

Table 7. Helium-3 and helium-4 analyses used to determine age of water samples from well PM-2, November 29-December 1, 1993

[Analysis by Lawrence Livermore National Laboratory]

\begin{tabular}{cccc}
\hline $\begin{array}{c}\text { Sample depth } \\
\text { (meters below } \\
\text { land surface) }\end{array}$ & $\begin{array}{c}\text { Helium-3 } \\
\text { atoms/L }\end{array}$ & $\begin{array}{c}\text { Helium-4 } \\
\text { atoms/L }\end{array}$ & $\begin{array}{c}\text { Helium-3/ } \\
\text { tritium } \\
\text { age since } \\
\text { May } 1994\end{array}$ \\
\hline 610 & $7.86 \times 10^{9}$ & $1.75 \times 10^{14}$ & 3,348 days \\
915 & $5.36 \times 10^{9}$ & $1.43 \times 10^{14}$ & 3,162 days \\
\hline
\end{tabular}

\section{Gamma Spectral}

Both LLNL and LANL performed gamma spectral analyses on water samples collected from well PM-2 in November-December 1993 and in May 1994. Because LANL had a larger available sample size, a more sensitive gamma spectral analysis was done. In the procedure used by LLNL, a relatively small sample aliquot $(0.5 \mathrm{~L})$ was placed within an "uplooker" $\mathrm{Ge}$ detector and counted for 5 days. LLNL analyzed unfiltered samples, filtered samples, and the non-filterable residue. Complete results of LLNL analysis with the analytical detection limits are presented in Appendix E. LANL used an evaporation procedure appropriate for the larger volume $(2.2 \mathrm{~L})$ available to them. After evaporation, the sample residue was counted for 3,000 minutes (about 2 days) on a Ge counter. Summary analysis results from LLNL and LANL are given in table 8 .

Both laboratory analyses show that the gamma radiation in well PM-2 was minor. Most of the water samples contain no gamma-emitting radionuclides. Of the three measurable radionuclides found $-{ }^{137} \mathrm{Cs}$, ${ }^{226} \mathrm{Ra}$, and ${ }^{125} \mathrm{Sb}-$ none had an activity greater than $3 \mathrm{~Bq} / \mathrm{L}$. Most likely, the ${ }^{226} \mathrm{Ra}$ detected by LLNL is a natural decay from ${ }^{238} \mathrm{U}$ (G.J. Nimz, LLNL, written commun., 1994). Confirmation of this would require an analysis of the rocks adjacent to the well for their 
Table 8. Gamma spectral analysis of water samples from well PM-2, 1993-94

[Abbreviations: b.d.l., below detection limit; Bq/L, becquerels per liter; n.d., not detected; m.w., molecular weight]

\begin{tabular}{|c|c|c|c|c|c|c|c|c|c|}
\hline \multirow{4}{*}{$\begin{array}{l}\text { Sample } \\
\text { depth } \\
\text { (meters } \\
\text { below } \\
\text { land } \\
\text { surface) }\end{array}$} & \multicolumn{6}{|c|}{ Sampling and analysis by Lawrence Livermore National Laboratory } & \multicolumn{3}{|c|}{$\begin{array}{l}\text { Sampling and analysis by Los Alamos } \\
\text { National Laboratory }\end{array}$} \\
\hline & \multirow{2}{*}{\multicolumn{2}{|c|}{$\begin{array}{c}\begin{array}{c}\text { Sampling of } \\
11 / 29-12 / 01 / 93\end{array} \\
\begin{array}{c}\text { Radium-226 } \\
(\mathrm{Bq} / \mathrm{L})\end{array}\end{array}$}} & \multicolumn{4}{|c|}{ Sampling of $05 / 3-4 / 94$} & \multicolumn{2}{|c|}{$\begin{array}{l}\text { Sampling of } \\
11 / 29-12 / 01 / 93\end{array}$} & \multirow{3}{*}{$\begin{array}{c}\begin{array}{c}\text { Sampling } \\
\text { of } 05 / 3-4 / 94\end{array} \\
\begin{array}{c}\text { Cesium-137 } \\
(B q / L)\end{array}\end{array}$} \\
\hline & & & \multicolumn{2}{|c|}{$\begin{array}{l}\text { Radium-226 } \\
\qquad(B q / L)\end{array}$} & \multirow{2}{*}{$\begin{array}{c}\begin{array}{c}\text { Antimony- } \\
125 \\
(\mathrm{~Bq} / \mathrm{L})\end{array} \\
\begin{array}{c}\text { Filtered } \\
\text { water }\end{array}\end{array}$} & \multirow{2}{*}{$\begin{array}{c}\begin{array}{c}\text { Cesium- } \\
137 \\
(\mathrm{~Bq} / \mathrm{L})\end{array} \\
\begin{array}{c}\text { Filtered } \\
\text { water }\end{array}\end{array}$} & \multirow[t]{2}{*}{$\begin{array}{c}\text { Antimony- } \\
125 \\
(B q / L)\end{array}$} & \multirow[t]{2}{*}{$\begin{array}{l}\text { Cesium-137 } \\
\text { (Bq/L) }\end{array}$} & \\
\hline & $\begin{array}{l}\text { Unfiltered } \\
\text { water }\end{array}$ & $\begin{array}{l}10,000 \\
\text { m.w. } \\
\text { filter }\end{array}$ & $\begin{array}{l}\text { Unfiltered } \\
\text { water }\end{array}$ & $\begin{array}{l}10,000 \\
\text { m.w. } \\
\text { filter }\end{array}$ & & & & & \\
\hline 305 & 0.615 & 0.0667 & 0.123 & 0.0378 & 0.0168 & 0.00881 & n.d. & n.d. & n.d. \\
\hline 610 & b.d.1. & n.d. & \multicolumn{4}{|c|}{ (not sampled) } & \multicolumn{2}{|l|}{ (not sampled) } & \\
\hline 823 & 0.0878 & n.d. & b.d.l. & n.d. & b.d.l. & 0.0349 & n.d. & trace & 0.01 \\
\hline 915 & b.d.l. & n.d. & b.d.l. & 0.0256 & b.d.l. & b.d.l. & 0.02 & 2.4 & $0.096 \pm 0.054$ \\
\hline
\end{tabular}

U concentrations, and also would require U-series analysis for well PM-2 water (G.J. Nimz, LLNL, written commun., 1994).

The detection of ${ }^{125} \mathrm{Sb}$ is not an uncommon occurrence near cratering events. Substantial amounts of radioactive $\mathrm{Sb}$ have been detected in postshot debris (J.L. Thompson, LANL, written commun., 1994). Pb used as shielding for the Schooner event was "Sb hardened." When the event was detonated, the neutron activation would produce ${ }^{125} \mathrm{Sb}$. A substantial amount of $\mathrm{Pb}$ was used because Schooner was a cratering experiment (J.L. Thompson, LANL, written commun., 1994).

LANL also collected some of the sludge from well PM-2 at an approximate depth of $984 \mathrm{~m}$. Two small cinders from the land surface, between well PM-2 and Schooner, were analyzed also. No gamma emitters were detected during laboratory analysis of the sludge; the cinders contained several becquerels of ${ }^{60} \mathrm{Co},{ }^{154} \mathrm{Eu},{ }^{152} \mathrm{Eu},{ }^{137} \mathrm{Cs}$, and ${ }^{133} \mathrm{Ba}$, lesser amounts of ${ }^{108} \mathrm{Ag}$, and possibly ${ }^{150} \mathrm{Eu}$ and ${ }^{155} \mathrm{Eu}$ (J.L. Thompson, LANL, written commun., 1994).

\section{Gross Alpha and Gross Beta}

Gross alpha and gross beta were analyzed by LLNL of the samples collected during November 29December 1, 1993, and during May 3-4, 1994 (Appendix E). Water samples from depths of $305 \mathrm{~m}, 610 \mathrm{~m}$, $823 \mathrm{~m}$, and $915 \mathrm{~m}$ were analyzed. The gross alpha and beta counts of all the samples were below detection limits of about $3 \mathrm{~Bq} / \mathrm{L}$.

\section{Plutonium}

Results of the analysis by LLNL of the combined activity of ${ }^{238} \mathrm{Pu}$ and ${ }^{239} \mathrm{Pu}$ are presented in table 9. No isotopes were detected at depths of 305 and $610 \mathrm{~m}$. A small amount (average activity of $0.00444 \mathrm{~Bq} / \mathrm{L}$ ) of the $\mathrm{Pu}$ isotopes were present at a depth of $915 \mathrm{~m}$ and smaller amounts $(0.00163 \mathrm{~Bq} / \mathrm{L})$ at a depth of $823 \mathrm{~m}$. The measured $\mathrm{Pu}$ isotopic ratios suggest Schooner as a possible source of contamination and further support the belief that contamination was washed in from the surface (G.J. Nimz, LLNL, written commun., 1994).

Table 9. Analysis of combined plutonium-238 and plutonium-239 in raw water samples from well PM-2, May 3-4, 1994

[Sampling and analysis by Lawrence Livermore National Laboratory. Abbreviations: b.d.l., below detection limit; $\mathrm{Bq} / \mathrm{L}$, Bequerels per liter]

\begin{tabular}{ccc}
$\begin{array}{c}\text { Depth } \\
\text { (meters) }\end{array}$ & $\begin{array}{c}\text { Activity } \\
\text { (Bq/L) }\end{array}$ & $\begin{array}{c}\text { Error } \\
\mathbf{+ 2 \sigma} \sigma\end{array}$ \\
\hline 305 & $<2.5 \mathrm{E}-04$ & b.d.l. \\
823 & $1.63 \mathrm{E}-03$ & $4.15 \mathrm{E}-04$ \\
915 & $4.33 \mathrm{E}-03$ & $6.85 \mathrm{E}-04$ \\
\hline
\end{tabular}

\section{Inorganic Constituents}

During November 1993, REECo Analytical Services analyzed water collected by the USGS on September 27, 1993, from a depth of $610 \mathrm{~m}$ in well PM-2. Analytical results of inorganic constituents are shown in Appendix F. To obtain sufficient sample volume for analysis, the sample was diluted by a factor of 2.3 , for 
a final volume of $1,000 \mathrm{~mL}$. During the preparation of the sample for metals analysis, $100 \mathrm{~mL}$ of the remaining $1,000 \mathrm{~mL}$ sample was digested and concentrated to a final volume of $50 \mathrm{~mL}$, or a concentration factor of 2.0 , to obtain as close a concentration as possible to the original sample (F.D. Ferate, REECo, written commun., 1994). Al (0.13 mg/L) exceeded the USEPA secondary maximum contaminant level (SMCL) of 0.05 to $0.2 \mathrm{mg} / \mathrm{L}$. $\mathrm{Mn}(0.11 \mathrm{mg} / \mathrm{L})$ and $F e(2.8 \mathrm{mg} / \mathrm{L})$ also exceeded the SMCL's of 0.05 and $0.3 \mathrm{mg} / \mathrm{L}$, respectively (U.S. Environmental Protection Agency, 1996).

LLNL analyzed for inorganic constituents in water samples collected from well PM-2 during November 29-December 1, 1993. The results of the analyses are presented in Appendix E. Except for $\mathrm{Na}$, concentrations of constituents listed in Appendix $\mathrm{E}$ were relatively low. Five of the constituents $(\mathrm{Al}, \mathrm{B}, \mathrm{Li}$, $\mathrm{Mg}, \mathrm{P}$ ) were present in concentrations of less than 1 $\mathrm{mg} / \mathrm{L}$. Six other constituents $(\mathrm{Ca}, \mathrm{Cl}, \mathrm{Fe}, \mathrm{K}, \mathrm{S}, \mathrm{Si})$ were present in concentrations of less than $20 \mathrm{mg} / \mathrm{L}$ in all the samples collected. Al exceeded USEPA SMCL $(0.05-0.2 \mathrm{mg} / \mathrm{L})$ at $915 \mathrm{~m}(0.14 \mathrm{mg} / \mathrm{L})$. Fe also exceeded the SMCL $(0.3 \mathrm{mg} / \mathrm{L})$ at $610 \mathrm{~m}(1.29 \mathrm{mg} / \mathrm{L})$, $823 \mathrm{~m}(1.22 \mathrm{mg} / \mathrm{L})$, and $915 \mathrm{~m}(2.40 \mathrm{mg} / \mathrm{L})$.

The concentrations of $\mathrm{B}, \mathrm{Fe}, \mathrm{K}, \mathrm{Na}, \mathrm{Si}$ and $\mathrm{S}$ more than doubled from the $305-\mathrm{m}$ sample to the $610-\mathrm{m}$ sample. $\mathrm{Na}$ increased in concentration from $26 \mathrm{mg} / \mathrm{L}$ in the shallowest sample to more than $1,000 \mathrm{mg} / \mathrm{L}$ in all the deeper samples. Differences in the concentrations of these six constituents in the samples taken at depths of $610 \mathrm{~m}, 823 \mathrm{~m}$, and $915 \mathrm{~m}$, were slight.

The largest increase in most trace constituents listed in Appendix $\mathrm{E}$ was between the samples taken at $305 \mathrm{~m}$ and $610 \mathrm{~m}$ below land surface. Eight of the constituents $(\mathrm{Cr}, \mathrm{Cu}, \mathrm{Pb}, \mathrm{Hg}, \mathrm{Mo}, \mathrm{Ni}, \mathrm{Se}, \mathrm{U})$ were at least an order of magnitude higher in concentration in the 610-m sample than the $305-\mathrm{m}$ sample. The largest increase in concentration is present in five constituents $(\mathrm{Cr}, \mathrm{Cu}, \mathrm{Mo}, \mathrm{Se}, \mathrm{Sr}$ ). Mn was the only constituent found higher in concentration (by an order of magnitude) in the $305-\mathrm{m}$ sample than in the $610-\mathrm{m}$ sample. $\mathrm{Co}, \mathrm{Hg}$, and $\mathrm{U}$ were found in concentrations of less than $10 \mu \mathrm{g} / \mathrm{L}$ in all the sample depths. Half of the constituents listed in Appendix E (Ba, Cr, $\mathrm{Mn}, \mathrm{Mo}, \mathrm{Se}, \mathrm{Sr}$, $\mathrm{Zn}$ ) were found to exceed $100 \mu \mathrm{g} / \mathrm{L}$ in at least one sample depth.

$\mathrm{Hg}$ and Se exceeded the USEPA MCL's $(2 \mu \mathrm{g} / \mathrm{L}$ and $50 \mu \mathrm{g} / \mathrm{L}$, respectively $)$ at depths of $610 \mathrm{~m}(7.9 \mu \mathrm{g} / \mathrm{L}$ and $127 \mu \mathrm{g} / \mathrm{L}$, respectively), $823 \mathrm{~m}(7.9 \mu \mathrm{g} / \mathrm{L}$ and 71 $\mu \mathrm{g} / \mathrm{L}$, respectively), and $915 \mathrm{~m}(9.8 \mu \mathrm{g} / \mathrm{L}$ and
$118.1 \mu \mathrm{g} / \mathrm{L}$ respectively). Mn exceeded the USEPA SMCL $(50 \mu \mathrm{g} / \mathrm{L})$ at $305 \mathrm{~m}(124.5 \mu \mathrm{g} / \mathrm{L})$ and at $915 \mathrm{~m}$ $(74.8 \mu \mathrm{g} / \mathrm{L})$.

\section{Organic Compounds}

During November 1993, REECo Analytical Services analyzed water collected by the USGS on September 27, 1993, from a depth of $610 \mathrm{~m}$ in well PM-2. Analytical results of semivolatile organics are shown in Appendix F. The 450-mL sample was diluted to obtain a sufficient volume for analysis. The sample was diluted by a factor of 2.3 , for a final volume of 1,000 $\mathrm{mL}$. Semi-volatile organic analyses detected only one compound, bis (2-ethylhexyl) phthalate. The phthalate detected may be due to contamination during the extensive handling of this sample (F.D. Ferate, REECo, written commun., 1994).

LLNL also analyzed for organic compounds in water samples collected from well PM-2 during November 29-December 1, 1993 (table 10). Samples for volatile and semivolatile organic compounds exceeded LLNL's recommended holding times, and results may not be representative of samples analyzed within recommended holding times. Low concentrations (less than $200 \mu \mathrm{g} / \mathrm{L}$ ) of nine organic compounds were detected and no compounds were found in the water sample from $610 \mathrm{~m}$. The only compound found in concentration greater than $100 \mu \mathrm{g} / \mathrm{L}$ was 4methylphenol at depths of $823 \mathrm{~m}$ and $915 \mathrm{~m}$. The total concentration of organic compounds did not exceed $300 \mu \mathrm{g} / \mathrm{L}$ in any sample.

Two compounds (1,1,2-trichloroethane, dimethyl ether) were found in samples from depths of $305 \mathrm{~m}$ and $823 \mathrm{~m}$. Three compounds [4-methylphenol, bis(2ethylhexyl)phthalate, di-n-butylphthalate] were found in samples from $823 \mathrm{~m}$ and $915 \mathrm{~m}$. These three compounds were the only semivolatile compounds detected. All the other compounds are volatile.

\section{SUMMARY}

Analysis of water collected during August and September 1993 from well PM-2, on Pahute Mesa at the Nevada Test Site, indicated ${ }^{3} \mathrm{H}$ concentrations of $21,000 \mathrm{~Bq} / \mathrm{L}$. The Schooner event (U-20u) was detonated in 1968 approximately $270 \mathrm{~m}$ southeast of well PM-2 at a working depth of $108.2 \mathrm{~m}$. The crater created by the Schooner event was about $129.8 \mathrm{~m}$ in radius and $63.4 \mathrm{~m}$ in depth. The continuous ejecta limit was 
Table 10. Volatile and semivolatile organic compounds in water samples from well PM-2, November 29-December 1, 1993

[Sampling and analysis by Lawrence Livermore National Laboratory]

\begin{tabular}{|c|c|}
\hline $\begin{array}{l}\text { Organic } \\
\text { compound }\end{array}$ & $\begin{array}{c}\text { Concentration, } \\
\text { in micrograms } \\
\text { per liter }\end{array}$ \\
\hline \multicolumn{2}{|c|}{ Sample depth 305 meters below land surface } \\
\hline Benzene & 4.2 \\
\hline Chloromethane & 2.0 \\
\hline Methylchloride & 0.3 \\
\hline 1,1,2-Trichloroethane & 0.5 \\
\hline Dimethyl ether & 20.0 \\
\hline \multicolumn{2}{|c|}{ Sample depth 610 meters below land surface } \\
\hline \multicolumn{2}{|c|}{ No organic compounds detected } \\
\hline \multicolumn{2}{|c|}{ Sample depth 823 meters below land surface } \\
\hline Carbondisulfide & 1.0 \\
\hline 1,1,2-Trichloroethane & 0.5 \\
\hline Dimethyl ether & 20.0 \\
\hline 4-methylphenol & 190.0 \\
\hline Di-n-butylphthalate ${ }^{l}$ & 21.0 \\
\hline Bis(2-ethylhexyl)phthalate ${ }^{\prime}$ & 35.0 \\
\hline \multicolumn{2}{|c|}{ Sample depth 915 meters below land surface } \\
\hline 4-methylphenol & 120.0 \\
\hline Di-n-butylphthalate ${ }^{l}$ & 18.0 \\
\hline Bis (2-ethylhexyl) phthalate & 25.0 \\
\hline
\end{tabular}

asymmetrical, ranging from about $518 \mathrm{~m}$ to $823 \mathrm{~m}$. The maximum extent to which earth materials were ejected exceeded $1,830 \mathrm{~m}$.

Geologic and hydrologic properties of the stratigraphic units are summarized from historical data. The soil around the well and water in the well were analyzed for radionuclides and water in the well was also analyzed for inorganic constituents and organic (volatile and semivolatile) substances.

Results of soil sampling indicate that radioactivity of identifiable nonnaturally occurring radionuclides $\left({ }^{241} \mathrm{Am},{ }^{60} \mathrm{Co},{ }^{137} \mathrm{Cs},{ }^{150} \mathrm{Eu}{ }^{150} \mathrm{Eu},{ }^{154} \mathrm{Eu}\right)$ were the same order of magnitude as that of the natural radionuclides $\left({ }^{40} \mathrm{Kr} 40,{ }^{226} \mathrm{Ra},{ }^{228} \mathrm{Th},{ }^{232} \mathrm{Th}\right)$. Gamma spectral analysis of each soil sample had numerous unidentified peaks with high counting errors.

${ }^{3} \mathrm{H}$ activity in water samples taken from depths of 258 and $305 \mathrm{~m}$ was about two orders of magnitude less than that in water samples taken from $610 \mathrm{~m}$ and below. The highest ${ }^{3} \mathrm{H}$ values (greater than $27,000 \mathrm{~Bq} / \mathrm{L}$ ) were at $610 \mathrm{~m}$ below land surface, which is above the shal- lowest perforations at $765 \mathrm{~m}$. These values are only slightly higher than values found at greater depth in the well. The lowest ${ }^{3} \mathrm{H}$ values ( 316 and $319 \mathrm{~Bq} / \mathrm{L}$ ) were found near the water surface in the well, at $258 \mathrm{~m}$ and $305 \mathrm{~m}$ below land surface. The analysis of ${ }^{3} \mathrm{H}$ activity in water samples appears consistent among samples collected at different times but at the same or similar depths. The variability of the analytical results may be a function of (1) the mixing of the water column within the borehole as the sampling device was lowered and raised, or, less likely, (2) movement of water into or out of the borehole.

Results for water samples collected from well PM-2 during November 1993 and May 1994 indicate that the concentration of gamma emitters was minormost samples contain no gamma-emitting radionuclides. Of the three radionuclide detected $-{ }^{137} \mathrm{Cs}$, ${ }^{226} \mathrm{Ra}$, and ${ }^{125} \mathrm{Sb}$-none had an activity greater than $3 \mathrm{~Bq} / \mathrm{L}$. The ${ }^{226} \mathrm{Ra}$ detected by LLNL may be natural decay from ${ }^{238} \mathrm{U}$. A small amount (average activity, $0.00433 \mathrm{~Bq} / \mathrm{L}$ ) of the $\mathrm{Pu}$ isotopes was present at a depth of $915 \mathrm{~m}$ and a smaller amount $(0.00163 \mathrm{~Bq} / \mathrm{L})$ at a depth of $823 \mathrm{~m}$.

Concentration of inorganic constituents increased with depth. The largest increase was between 305 and $610 \mathrm{~m}$ below land surface. Eight of the constituents $(\mathrm{Cr}$, $\mathrm{Cu}, \mathrm{Pb}, \mathrm{Hg}, \mathrm{Mo}, \mathrm{Ni}, \mathrm{Se}, \mathrm{U}$ ) were at least an order of magnitude higher in concentration in the $610-\mathrm{m} \mathrm{sam}$ ple. The largest increase in concentration is present in five of the constituents $(\mathrm{Cr}, \mathrm{Cu}, \mathrm{Mo}, \mathrm{Se}, \mathrm{Sr})$.

Low concentrations (less than $200 \mu \mathrm{g} / \mathrm{L}$ ) of nine organic compounds were detected. The only compound found in concentration greater than $100 \mu \mathrm{g} / \mathrm{L}$ was $4-$ methylphenol, detected by LLNL at depths of $825 \mathrm{~m}$ and $915 \mathrm{~m}$. The total concentration of organic compounds did not exceed $300 \mu \mathrm{g} / \mathrm{L}$ in any sample.

\section{REFERENCES CITED}

Blankennagel, R.K., and Weir, J.E., Jr., 1966, Well histories and drilling data on exploratory test holes, Pahute Mesa, Nevada Test Site: U.S. Geological Survey Special Studies I-46, 23 p.

1973, Geohydrology of the eastern part of Pahute Mesa, Nevada Test Site, Nye County, Nevada: U.S. Geological Survey Professional Paper 712-B, 35 p.

Blankennagel, R.K., Young, R.A., Cooper, J.B., and Whitcomb, H.A., 1964, Summary of ground-water data pertinent to underground construction and to water-supply development, Pahute Mesa, Nevada Test Site: U.S. Geological Survey Special Studies I-27, 39 p. 
EG\&G Energy Measurements, Inc., 1972, Radiological survey of the Nevada Test Site (survey period, 19701971): EG\&G Energy Measurements, Inc., Technical Report No. L-1064, 80 p. 1992, Off-site plutonium plume survey, Nevada Test Site, Date of Survey: October 10, 1992: EG\&G Energy Measurements, Inc., Survey Report NV-93-090, 22 p.

Gillespie, D., 1994, Evaluation of well PM-2 for addition to Environmental Surveillance Monitoring Network: University of Nevada, Desert Research Institute Report, $17 \mathrm{p}$.

Hasler, J.W., and Byers, F.M., Jr., 1965, Preliminary report on the lithology of Pahute Mesa drill hole No. 2, Pahute Mesa, Nevada Test Site: U.S. Geological Survey Special Studies I-39, $20 \mathrm{p}$.

Hem, J.D, 1985, Study and interpretation of the chemical characteristics of natural water [3d ed.]: U.S. Geological Survey Water-Supply Paper 2254, 263 p.

Henny, R.W., 1969, Schooner observations and early results: Air Force Weapons Laboratory, Technical Report AFWL-TR-69-133, $54 \mathrm{p}$.

Laczniak, R.J., Cole, J.C., Sawyer, D.A., and Trudeau, D.A., 1996, Summary of hydrogeologic controls on groundwater flow at the Nevada Test Site, Nye County, Nevada: U.S. Geological Survey Water-Resources Investigations Report 96-4109, 59 p.

O’Hagan, M.D., and Laczniak, R.J., 1996, Ground-water levels beneath eastern Pahute Mesa and vicinity, Nevada Test Site, Nye County, Nevada: U.S. Geological Survey Water-Resources Investigations Report 96-4042, 1 sheet.

Orkild, P.P., 1969, Review of existing and potential test sites in Areas 18, 19, and 20, Pahute Mesa, Nevada Test Site: U.S. Geological Survey Special Studies I-76, 13 p.

Orkild, P.P., and Jenkins, E.C., 1970, Report of exploration progress, Pahute Mesa, January 31, 1968 - October 1, 1969: U.S. Geological Survey Special Studies I-23-17, $83 \mathrm{p}$.
Purtymun, W.D., Harrill, J.R., and Rush, F.E., 1969, Geologic data for U20u satellite holes \#1, \#2, \#3, and \#4, and studies of the orientation of joints in the Thirsty Canyon Tuff, Area 20, Pahute Mesa, Nevada Test Site: U.S. Geological Survey Open-File Report, 19 p.

Romney, E.M., Essington, E.H., Fowler, E.B., Tamura, T., and Gilbert, R.O., 1987, Plutonium in the desert environment of the Nevada Test Site and the Tonopah Test Range: Symposium on Environmental Research on Actinide Elements, Hilton Head, S.C., November 1983, Proceedings, p. 121-130.

Thordarson, William, Young, R.A., and Winograd, I.J., 1967, Records of wells and test holes in the Nevada Test Site and vicinity (through December 1966): U.S. Geological Survey Open-File Report TEI-872, 26 p.

U.S. Department of Energy, 1994, United States nuclear tests, July 1945 through December 1992: Nevada Operations Office, DOE/NV-209 (Rev. 14), 112 p.

U.S. Environmental Protection Agency, 1996, Drinking water regulations and health advisories: Office of Water, U.S. Environmental Protection Agency, EPA 822-R-96-001, $11 \mathrm{p}$.

Warren, R.G., Sawyer, D.A., and Covington, H.R., 1989, Revised volcanic stratigraphy of the southwestern Nevada volcanic field, in Olsen C.W., and Carter, J.A., eds., Proceedings of Fifth Symposium on Containment of Underground Nuclear Explosions: Santa Barbara, Calif., Mission Research Corp., CONF-8909163, v. 2, $33 \mathrm{p}$.

Winograd, I.J., and Thordarson, William, 1975, Hydrogeologic and hydrochemical framework, south-central Great Basin, Nevada-California, with special reference to the Nevada Test Site: U.S. Geological Survey Professional Paper 712-C, $126 \mathrm{p}$. 


\section{APPENDIX A. Hole History, Well History, Core Samples, and Cementing Record for Well PM-2}

The information contained in Appendix A was provided by Raytheon Services Nevada (formerly Fenix \& Scisson). It is presented in the format provided to the USGS. 


\begin{tabular}{|c|c|c|c|c|c|c|c|c|c|c|}
\hline \multicolumn{4}{|c|}{ HOLE No.: Pahute \#2 } & \multicolumn{3}{|c|}{ W.O. No.: $1160-36$} & \multicolumn{4}{|c|}{ I.D. No.: 1131} \\
\hline \multicolumn{2}{|l|}{ USER: } & \multicolumn{2}{|l|}{ LRL } & \multicolumn{3}{|c|}{ TYPE HOLE: } & oratory & & & \\
\hline \multicolumn{4}{|c|}{ LOCATION: NTS } & \multicolumn{3}{|c|}{ COUNTY: Nye } & \multicolumn{4}{|c|}{ AREA: 20} \\
\hline \multicolumn{7}{|c|}{ SURFACE COORDINATES: N 944,581.79 E 528,655.28 } & \multicolumn{4}{|c|}{ GROUND ELEVATION: $5585.6^{\prime}$} \\
\hline \multicolumn{4}{|c|}{ RIG ON LOCATION: 5-20-64 } & \multicolumn{3}{|c|}{ SPUDDED: 5-20-64 } & \multicolumn{4}{|c|}{ COMPLETED: $10-13-64$} \\
\hline \multicolumn{11}{|c|}{ REMARKS: Static water level approximately $1300^{\prime}}$. \\
\hline \multicolumn{11}{|c|}{ CIRCULATING MEDIA: Air, soap and water to $6450^{\prime}$ and mud to $8782^{\prime}$. } \\
\hline \multicolumn{11}{|c|}{ No. of COMPRESSORS \& SIZE: 8 Gardner Denver $(900 \mathrm{cfm})$} \\
\hline \multicolumn{11}{|c|}{ TYPE DRILLING EQUIPMENT: Bethleham MA-10 } \\
\hline \multicolumn{3}{|c|}{ BORE HOLE RECORD } & \multicolumn{8}{|c|}{ CASING RECORD } \\
\hline FROM & TO & SIZE & I.D & WT/FT. & WALL & GRADE & CPL'G. & FROM & TO & CU.FT.CMT \\
\hline $\begin{array}{l}0^{\prime} \\
44^{\prime}\end{array}$ & $\begin{array}{c}44^{\prime} \\
2507^{\prime}\end{array}$ & $\begin{array}{c}26^{\prime \prime} \\
17-1 / 2^{\prime \prime}\end{array}$ & $\begin{array}{c}19.25^{\prime \prime} \\
12.615^{\prime \prime}\end{array}$ & $\begin{array}{l}78.6 \# \\
54.5 \#\end{array}$ & $\begin{array}{l}.375^{\prime \prime} \\
.380^{\prime \prime}\end{array}$ & $\underset{\mathrm{J}-55}{\mathrm{H}-40}$ & $\begin{array}{l}\text { BW } \\
8 \mathrm{R}\end{array}$ & $\begin{array}{l}0^{\prime} \\
0^{\prime}\end{array}$ & $\begin{array}{c}44^{\prime} \\
2492^{\prime}\end{array}$ & $\begin{array}{c}150 * * \\
3240\end{array}$ \\
\hline $2507^{\prime}$ & $5498^{\prime}$ & $12-1 / 4^{\prime \prime}$ & $\begin{array}{l}8.921 " \\
8.835^{\prime \prime}\end{array}$ & $\begin{array}{l}36.0 \# \\
40.0 \#\end{array}$ & $\begin{array}{l}.352^{\prime \prime} \\
.395^{\prime \prime}\end{array}$ & $\begin{array}{c}J-55 \\
\text { N-80 }\end{array}$ & ST\&C & $\begin{array}{c}0^{\prime} \\
3674^{\prime}\end{array}$ & $\begin{array}{l}3674^{\prime} \\
5498^{\prime}\end{array}$ & 860 \\
\hline $\begin{array}{l}5498^{\prime} \\
8775^{\prime}\end{array}$ & $\begin{array}{l}8775^{\prime} \\
8782^{\prime}\end{array}$ & $\begin{array}{l}8-5 / 8^{\prime \prime} \\
6-1 / 8^{\prime \prime}\end{array}$ & & & & & & & & \\
\hline \multicolumn{4}{|c|}{ TOTAL DEPTH: $8782^{\prime}$} & \multicolumn{3}{|c|}{ MANDREL DEPTH: NONE } & \multicolumn{4}{|c|}{ PLUGS: NONE } \\
\hline \multicolumn{11}{|c|}{ JUNK: $\quad$ None } \\
\hline \multicolumn{11}{|c|}{ RIG DATA: See surveys, page 8 and a list of logs, page 10.} \\
\hline \multicolumn{4}{|c|}{ DEV. DATA M.D.: $6450^{\prime}$} & \multicolumn{3}{|c|}{ T.V.D.: $6446.19^{\prime}$} & REFEREI & CE: $151-S$ & -267 In Run & \\
\hline BOTTON & OLE CO & DINATES & N $944,581.15$ & $528,655.45$ & $446.19^{\prime}$ & & & & & \\
\hline CORING & ATA: See & Data, pa & & & & & & & & \\
\hline & N-OPER & IONAL T & ME & OPERATIC & AL DEL & IY TIME & & TIME & UMMARY & \\
\hline Move Rig & \& down & & ${ }^{*}$ days & Equipment & & 9.5 days & Starting D & & $05-20-64$ & \\
\hline Secured & & & 1.9 days & Caving & & 31.8 days & Completio & Date: & $10-13-64$ & \\
\hline Suspende & & & days & Lost Circ. & & 5.2 days & Elapse Tin & & 145.87 days & \\
\hline Bail \& R & Mandrel & & days & Fishing & & 2.2 days & Total N_O & Time & 26.5 days & \\
\hline Logging & & & 7.7 days & Other & & days & Total O_D & Time & 48.7 days & \\
\hline Survey & & & 1.6 days & & & & Working $T$ & me & 42.97 days & \\
\hline Casing & & & .6 days & & & & Trips & & 27.7 & \\
\hline Cement & & & 4.7 days & & & & & & & \\
\hline Coring & & & 4.3 days & & & & & & & \\
\hline Other & & & 5.7 days & & & & & & & \\
\hline TOTAL & & & 26.5 days & TOTAL & & 48.7 days & & & & \\
\hline REMARK & $\begin{array}{l}\text { Prepared } \\
\text { No rig-u } \\
50 \mathrm{ft}^{3} \text { in }\end{array}$ & $\begin{array}{l}\text { Bruesc } \\
\text { down tim } \\
\text { casing. }\end{array}$ & $\begin{array}{l}\text { N. Fowler: } \\
\text { hown in this }\end{array}$ & port. & & & & & & \\
\hline
\end{tabular}




\section{WELL HISTORY \\ Pahute Mesa Exploratory Hole \#2}

5-20-64 Bethleham MA-10 rig on location and rigged up at 0800 hours. Drilled $121 / 4^{\prime \prime} \mathrm{h}$ ole from $0^{\prime}$ to $44^{\prime}$. Reamed $121 / 4^{\prime \prime}$ hole to $26^{\prime \prime}$ hole.

5-21-64 Finished reaming 121/4" hole to $26^{\prime \prime}$ to $44^{\prime}$. Ran 20" O.D. casing to $44^{\prime}$. Cemented with $50 \mathrm{cu}$. ft. of 50-50 cal seal and neat cement inside the casing.

5-22-64 Finished cementing 20" casing with $100 \mathrm{cu}$. $\mathrm{ft}$. of neat cement and $2 \% \mathrm{CaC} 12$ down the annulus.

5-23-64 Drilled out cement and drilled $121 / 4^{\prime \prime}$ hole form $44^{\prime}$ to $135^{\prime}$. Reamed $121 / 4^{\prime \prime}$ hole to $171 / 2^{\prime \prime}$ hole from $44^{\prime}$ to 135 .

5-24-64 Drilled $171 / 2^{\prime \prime}$ hole from $135^{\prime}$ to $320^{\prime}$.

5-25-64 Cored from $320^{\prime}$ to $327^{\prime}$ with $5^{\prime}$ of recovery. Drilled $171 / 2^{\prime \prime}$ hole from $320^{\prime}$ to 445 .

5-26-64 Drilled $171 / 2^{\prime \prime}$ hole from $446^{\prime}$ to $512^{\prime}$. Left bit, bit sub, and bottom drill collar in hole. Fish for and recovered same with $101 / 4^{\prime \prime}$ overshot. Cored from 512' to 519 with no recovery.

5-27-64 Drilled $171 / 2^{\prime \prime}$ hole from $512^{\prime}$ to 562 . Cored from $521^{\prime}$ to $536^{\prime}$ with no recovery. Worked on equipment.

5-28-64 Drilled $171 / 2^{\prime \prime}$ hole from $550^{\prime}$ to $887^{\prime}$. Cored from $550^{\prime}$ to $566^{\prime}$ with $90 \%$ recovery and from $887^{\prime}$ to $895^{\prime}$ with $100 \%$ recovery.

5-29-64 Drilled $171 / 2^{\prime \prime}$ hole from $887^{\prime}$ to $1312^{\prime}$. Cored from $1085^{\prime}$ to $1092^{\prime}$ with $5^{\prime}$ of recovery.

5-30-64 Drilled $171 / 2^{\prime \prime}$ hole from $1312^{\prime}$ to $1510^{\prime}$. Cored from $1312^{\prime}$ to $1319^{\prime}$ with $6^{\prime}$ recovery and from $1510^{\prime}$ to $1517^{\prime}$ with full recovery.

5-31-64 Drilled 17 1/2" hole from $1510^{\prime}$ to $1800^{\prime}$

6-1-64 Drilled $171 / 2^{\prime \prime}$ hole from $1800^{\prime}$ to $2056^{\prime}$. Cored from $1807^{\prime}$ to $1819^{\prime}$ with $7^{\prime}$ of recovery.

6-2-64 Drilled $171 / 2^{\prime \prime}$ hole from 2056 to $2226^{\prime}$. Cored from $2100^{\prime}$ to $2108^{\prime}$ with $100 \%$ recovery.

6-3-64 Drilled $171.2^{\prime \prime}$ hole from 2226 to $2400^{\prime}$.

6-4-64 Drilled $171 / 2^{\prime \prime}$ hole from $2400^{\prime}$ to $2500^{\prime}$. Cored from $2400^{\prime}$ to $2407^{\prime}$ with $100 \%$ recovery and from $2500^{\prime}$ to 2407 with $90 \%$ recovery.

6-5-64 Drilled $141 / 2^{\prime \prime}$ hole from $2500^{\prime}$ to $2507^{\prime}$. Prepared to log.

6-6-64 Ran Birdwell caliper, density, temperature and electric logs to 2470. 
Well History Pahute Mesa Exploratory Hole \#2

Page -2-

6-7-64 Cleaned hole to run casing. Ran 13 3/8" O.D. Casing to 2492'. Cemented Stage @1 with $800 \mathrm{ft}^{3}$ of $1-1$ neat cement and perlite with $4 \%$ dry gel, $2 \% \mathrm{CaC} 12$ and $1 \%$ Halad-9; followed by $150 \mathrm{ft}^{3}$ of neat cement with $2 \% \mathrm{CaCl}_{2}$ added. Cemented stage $\# 2$ with $500 \mathrm{ft}^{3}$ of 1-1 neat cement and perlite with $2 \% \mathrm{CaCl}_{2}$ and $2 \%$ gel.

6-8-64 Cemented Stage \#3 with $750 \mathrm{ft}^{3}$ of 1-1 neat cement and perlite, $2 \% \mathrm{CaC} 12$ and $2 \%$ gel. Tagged top of cement with wire line at $330^{\prime}$. Cemented Stage \#4 with $590 \mathrm{ft}^{3}$ of neat cement and $2 \% \mathrm{CaC} 12$. Tagged top of cement at $230^{\prime}$. Cemented Stage \#5 to surface with $450 \mathrm{ft}^{3}$ of 1-1 neat cement and perlite, $4 \%$ dry gel and $2 \% \mathrm{CaC} 12$.

6-9-64 Nippled up. Drilled $95 / 8^{\prime}$ hole through cement to $2495^{\prime}$.

6-10-64 Drilled cement from $2495^{\prime}$ to $2507^{\prime}$ with $95 / 8^{\prime \prime}$ bit. Drilled $95 / 8^{\prime \prime}$ hole from $2507^{\prime}$ to $2700^{\prime}$. Prepared to core. Cleaned out $90^{\prime}$ of fill on the bottom.

6-11-64 Drilled $95 / 8^{\prime \prime}$ hole from $2700^{\prime}$ to $2952^{\prime}$. Cored from $2700^{\prime}$ to $2707^{\prime}$ with full recovery.

6-12-64 Drilled $95 / 8^{\prime \prime}$ hole from $2952^{\prime}$ to $3190^{\prime}$. Cored from $2952^{\prime}$ to $2959^{\prime}$ and from $3190^{\prime}$ to $3196^{\prime}$ with full recovery.

6-13-64 Drilled $95 / 8^{\prime \prime}$ hole from $3190^{\prime}$ to $3543^{\prime}$. Cored from $3447^{\prime}$ to $3449^{\prime}$ with full recovery.

6-14-64 Drilled $95 / 8^{\prime \prime}$ hole from $3543^{\prime}$ to $3820^{\prime}$. Cored from $3680^{\prime}$ to $3687^{\prime}$ with full recovery.

6-15-64 Drilled $95 / 8^{\prime \prime}$ hole from $3820^{\prime}$ to $4000^{\prime}$. Cored from $3900^{\prime}$ to $3907^{\prime}$ with full recovery.

6-16-64 Drilled $95 / 8^{\prime \prime}$ hole from $4000^{\prime}$ to $4175^{\prime}$. Cored from $4100^{\prime}$ to $4107^{\prime}$ with $4^{\prime}$ of recovery.

6-17-64 Made trip for core barrel. Cleaned out 70' of fill after trip. Cored from $4175^{\prime}$ to $4182^{\prime}$. Found $32^{\prime}$ of fill after coring. Washed out same.

6-18-64 Cleaned out and reamed hole from $4150^{\prime}$ to $4182^{\prime}$. Hole kept caving in. Drilled $95 / 8^{\prime \prime}$ hole from $4182^{\prime}$ to $4211^{\prime}$.

6-19-64 Drilled 9 5/8" hole from 4211' to 4292'. Cleaned hole with core barrel at 3942'. Made a trip for bit. Cleaned hole to $4292^{\prime}$.

6-20-64 Drilled $95 / 8^{\prime \prime}$ hole from $4292^{\prime}$ to $4322^{\prime}$. Cleaned out hole for core. Cored from $4322^{\prime}$ to $4329^{\prime}$ with full recovery.

6-21-64 Drilled 9 5/8" hole form 4322' to 4515'.

6-22-64 Drilled $95 / 8^{\prime \prime}$ hole from $4515^{\prime}$ to $4637^{\prime}$. Cored from $4532^{\prime}$ to $4537^{\prime}$ with full recovery.

6-23-64 Drilled $95 / 8^{\prime \prime}$ hole from $4637^{\prime}$ to $4750^{\prime}$. Cored from 4750 . Cored from $4750^{\prime}$ to $4757^{\prime}$ with $100 \%$ recovery. Hit bridge approximately $120^{\prime}$ off bottom. 
Well History Pahute Mesa Exploratory Hole \#2

6-24-94 Washed to bottom. Drilled $95 / 8^{\prime \prime}$ hole from $4750^{\prime}$ to $4970^{\prime}$.

6-25-64 Cored from $4970^{\prime}$ to $4975^{\prime}$ with full recovery. Repaired equipment.

6-26-64 Repaired equipment.

6-27-64 Repaired equipment. Drilled $95 / 8^{\prime \prime}$ hole from $4970^{\prime}$ to $5059^{\prime}$.

6-28-64 Drilled $95 / 8^{\prime \prime}$ hole from $5059^{\prime}$ to $5202^{\prime}$. Cored from $5202^{\prime}$ to $5204^{\prime}$ with full recovery.

6-29-64 Drilled $95 / 8^{\prime \prime}$ hole from $5202^{\prime}$ to $5534^{\prime}$.

6-30-64 Drilled $95 / 8^{\prime \prime}$ hole from $5534^{\prime}$ to $5617^{\prime}$. Cored from $5550^{\prime}$ to $5557^{\prime}$ with $3^{\prime}$ of recovery.

7-1-64 Drilled $95 / 8^{\prime \prime}$ hole from $5617^{\prime}$ to $5786^{\prime}$. Cored from $5786^{\prime}$ to $5792^{\prime}$ with no recovery.

7-2-64 Drilled $95 / 8^{\prime \prime}$ hole from $5786^{\prime}$ to $5892^{\prime}$. Cored from $5892^{\prime}$ to $5899^{\prime}$ with full recovery.

7-3-64 Drilled $95 / 8^{\prime \prime}$ hole from $5892^{\prime}$ to $6037^{\prime}$. Stuck drill pipe. Left (11) drill collars and (8) stands of drill pipe in hole. Went in hole with overshot but hit bridge. Cleaned hole with bit. Top of fish at 4940'.

7-4-64 Cleaned hole to fish. Went in hole with overshot.

7-5-64 Recovered fish. Went in hole with bit and hit bridge at 4067'. Washed out bridges.

7-6-64 Washed out bridges to bottom. Drilled $95 / 8^{\prime \prime}$ hole from $6037^{\prime}$ to $6080^{\prime}$. Made a short trip. Cleaned out $40^{\prime}$ of fill. Conditioned hole for logs.

7-7-64 Cleaned hole for logs. Made a short trip to check for fill. Hit bridge at $4180^{\prime}$. Washed to bottom. Nippled up for aerated water.

7-8-64 Cleaned out bridges.

7-9-64 Pulled out of hole and W.O water. Ran in hole with $95 / 8^{\prime \prime}$ bit to a bridge at $4067^{\prime}$. Cleaned out bridges.

7-10-64 Cleaned out bridges. Ran electric log and temperature survey.

7-11-64 Ran 3-D and velocity log. Ran salinometer log. Ran caliper log to 3983'.

7-12-64 Ran water tests.

7-13-64 Ran water tests. Ran Birdwell tracer injector log.

7-14-64 Ran Birdwell tracer injector log. Ran water tests.

7-15-64 Ran water tests.

7-16-94 Prepared Davis mix and injected mix in hole. Made a trip in hole. Unloaded hole at 6 stand intervals, starting at approximately $2250^{\prime}$. Mixed and injected Davis mix.

7-17-64 Nippled up. Reamed $95 / 8^{\prime \prime}$ hole to $121 / 4^{\prime \prime}$ from $2507^{\prime}$ to 3006. 
Well History Pahute Mesa Exploratory Hole \#2

Page -4-

7-18-64 Reamed 9 5/8" hole to $121 / 4^{\prime \prime}$ from $3006^{\prime}$ to $3476^{\prime}$.

7-19-64 Reamed 9 5/8" hole to $121 / 4^{\prime \prime}$ from $3476^{\prime}$ to $3893^{\prime}$.

7-20-64 Reamed $95 / 8^{\prime \prime}$ hole to $121 / 4^{\prime \prime}$ from $3893^{\prime}$ to $4045^{\prime}$.

7-21-64 Reamed 9 5/8" hole to $121 / 4^{\prime \prime}$ from 4045 'to $4152^{\prime}$. Mixed mud to use in hole instead of Davis mix.

7-22-64 Mixed mud and lost circulation material.

7-23-64 Mixed mud and lost circulation material. Washed to bottom with $95 / 8$ " bit. Reamed $95 / 8^{\prime \prime}$ hole to $121 / 4^{\prime \prime}$ from $4152^{\prime}$ to $4169^{\prime}$.

7-24-64 Reamed $95 / 8^{\prime \prime}$ hole to $121 / 4^{\prime \prime}$ from $4169^{\prime}$ to $4263^{\prime}$

7-25-64 Reamed $95 / 8^{\prime \prime}$ hole to $121 / 4^{\prime \prime}$ from $4263^{\prime}$ to $4297^{\prime}$. Cleaned out $95 / 8^{\prime \prime}$ hole.

7-26-64 Cleaned out $95 / 8^{\prime \prime}$ hole. Reamed $95 / 8^{\prime \prime}$ hole to $121 / 4^{\prime \prime}$ from $4297^{\prime}$ to $4398^{\prime}$.

7-27-64 Reamed out $95 / 8^{\prime \prime}$ hole to $121 / 4^{\prime \prime}$ from $4398^{\prime}$ to $4497^{\prime}$. Cleaned out hole from $4447^{\prime}$ to $4479^{\prime}$ with $95 / 8^{\prime \prime}$ bit.

7-28-64 Cleaned out $95 / 8^{\prime \prime}$ hole from $4479^{\prime}$ to $4578^{\prime}$.

7-29-64 Reamed $95 / 8^{\prime \prime}$ hole to $121 / 4^{\prime \prime}$ from $4447^{\prime}$ to $4625^{\prime}$.

7-30-64 Reamed $95 / 8^{\prime \prime}$ hole to $121 / 4^{\prime \prime}$ from $4625^{\prime}$ to $4750^{\prime}$.

7-31-64 Reamed 9 5/8" hole to $121 / 4^{\prime \prime}$ from $4750^{\prime}$ to $4888^{\prime}$.

8-1-64 Reamed $95 / 8^{\prime \prime}$ hole to $121 / 4^{\prime \prime}$ from $4888^{\prime}$ to $4970^{\prime}$.

8-2-64 Reamed $95 / 8^{\prime \prime}$ hole to $121 / 4^{\prime \prime}$ from $4970^{\prime}$ to $5068^{\prime}$.

8-3-64 Reamed $95 / 8^{\prime \prime}$ hole to $121 / 4^{\prime \prime}$ from $5068^{\prime}$ to $5163^{\prime}$.

8-4-64 Reamed $95 / 8^{\prime \prime}$ hole to $121 / 4^{\prime \prime}$ from $5163^{\prime}$ to $5288^{\prime}$.

8-5-64 Reamed $95 / 8^{\prime \prime}$ hole to $121 / 4^{\prime \prime}$ from $5288^{\prime}$ to $5359^{\prime}$.

8-6-64 Reamed $95 / 8^{\prime \prime}$ hole to $121 / 4^{\prime \prime}$ from $5359^{\prime}$ to $5436^{\prime}$.

8-7-64 Reamed $95 / 8^{\prime \prime}$ hole to $121 / 4^{\prime \prime}$ from $5436^{\prime}$ to $5500^{\prime}$. Ran Birdwell temperature log.

8-8-64 Ran Birdwell caliper, density and 3-D logs to 5500'.

8-9-64 Ran Birdwell continuous velocity and electric logs. 
8-10-64 Ran 45 joints 40\# N-80 (1823.62') and 88 joints $36 \#$ J-55 (3676') 9 5/8" csg. with Baker guide shoe and float collar and D.V. tool with metal petal basket $30^{\prime}$ below D.V. tool. D.V. tool set at $510^{\prime}$. Set $95 / 8^{\prime \prime}$ O.D. casing at $5498^{\prime}$. Cemented Stage \#1 with $350 \mathrm{ft}^{3}$ neat cement with $121 / 4^{\prime \prime}$ gilsonite/sack cement, 4\% gel, $1 \%$ FLAC and $0.2 \%$ of D-8; followed by $150 \mathrm{ft}^{3}$ of neat cement, $1 \%$ FLAC and $0.2 \%$ of D-8.

Checked cement top at $4145^{\prime}$. Cemented Stage \#2 to surface with Halliburton D.V. tool with $360 \mathrm{ft}^{3}$ neat cement and $2 \% \mathrm{CaC} 12$.

8-11-64 Unloaded hole. Drilled out cement and D.V. tool. Unloaded hole.

8-12-64 Drilled $85 / 8^{\prime \prime}$ hole from $5498^{\prime}$ to $5627^{\prime}$.

8-13-64 Drilled 85/8" hole from $5627^{\prime}$ to $5913^{\prime}$.

8-14-64 Drilled $85 / 8^{\prime \prime}$ hole from $5913^{\prime}$ to $6272^{\prime}$. Went to mist drilling.

8-15-64 Drilled 85/8" hole from $6272^{\prime}$ to $6450^{\prime}$. Attempted to core but plugged core barrel.

8-16-64 Attempted to core at $6450^{\prime}$ but again plugged core barrel. Went in hole with $85 / 8$ " bit and washed out a bridge at $5845^{\prime}$.

8-17-64 Washed out bridges and cleaned hole from $5825^{\prime}$ to $5860^{\prime}$.

8-18-64 Washed out bridge from $5845^{\prime}$ to $5860^{\prime}$. Attempted to dry up the hole.

8-19-64 Cleaned out hole to $6180^{\prime}$. Attempted to run Birdwell caliper log and hit bridge at $5817^{\prime}$. Cleaned out bridge from $5857^{\prime}$ to $5918^{\prime}$.

8-20-64 Ran Birdwell caliper log to 5801'. Secured rig on stand by ready.

8-21-64 Set Lynos Packers at 5780' and 5460' and squeezed 1680 gallons of AM9 into the formation.

8-22-94 Cleaned out hole to $6450^{\prime}$.

8-23-64 Attempted to core but hit bridge at $5845^{\prime}$. Cleaned out hole from $5845^{\prime}$ to $6430^{\prime}$.

8-24-64 Cleaned out hole. Waited on orders.

8-25-64 Cleaned out hole with aerated water. Mixed mud. Injected in the hole 500 bbls of mud.

8-26-64 Cleaned out hole with mud.

8-27-64 Cleaned out hole with mud.

8-28-64 Cleaned out hole with mud.

8-29-64 Cleaned out hole with mud. Stuck pipe at $6025^{\prime}$. Pumped pipe free. Stuck pipe at $6035^{\prime}$ and pulled loose. Added 500 bbls. diesel oil to mud.

8-30-64 Added 70 bbls. diesel oil to mud. Cleaned out hole to $6399^{\prime}$.

8-31-64 Cleaned out hole to $6450^{\prime}$.

9-1-64 Cleaned out hole. Drilled $85 / 8^{\prime \prime}$ hole from $6450^{\prime}$ to $6525^{\prime}$. 
9-2-64 Drilled $85 / 8^{\prime \prime}$ hole from $6525^{\prime}$ to $6550^{\prime}$. Cored, Core $\# 28$, from $6550^{\prime}$ to $6552^{\prime}$.

9-3-64 Finished coring Core \#28 from $6552^{\prime}$ to $6558^{\prime}$. Recovered $1^{\prime}$ of core. Drilled $85 / 8^{\prime \prime}$ hole from $6550^{\prime}$ to $6597^{\prime}$.

9-4-64 Drilled $85 / 8^{\prime \prime}$ hole from $6597^{\prime}$ to $6650^{\prime}$.

9-5-64 Drilled $85 / 8^{\prime \prime}$ hole from $6650^{\prime}$ to $6748^{\prime}$.

9-6-64 Cored from $6748^{\prime}$ to $6753^{\prime}$ with $4^{\prime}$ of recovery. Drilled $85 / 8^{\prime \prime}$ hole from $6748^{\prime}$ to $6767^{\prime}$.

9-7-64 Drilled $85 / 8^{\prime \prime}$ hole from $6767^{\prime}$ to $6839^{\prime}$.

9-8-64 Drilled $85 / 8^{\prime \prime}$ hole from $6839^{\prime}$ to $6914^{\prime}$.

9-9-64 Drilled $85 / 8^{\prime \prime}$ hole from $6914^{\prime}$ to $6980^{\prime}$.

9-10-64 Drilled $85 / 8^{\prime \prime}$ hole from $6980^{\prime}$ to $7029^{\prime}$.

9-11-64 Drilled $85 / 8^{\prime \prime}$ hole from $7029^{\prime}$ to $7129^{\prime}$. Cored from $7029^{\prime}$ to $7035^{\prime}$ with full recovery.

9-12-64 Drilled $85 / 8^{\prime \prime}$ hole from $7129^{\prime}$ to $7196^{\prime}$.

9-13-64 Drilled $85 / 8^{\prime \prime}$ hole from $7196^{\prime}$ to $7242^{\prime}$.

9-14-64 Drilled $85 / 8^{\prime \prime}$ hole from $7242^{\prime}$ to $7305^{\prime}$.

9-15-64 Drilled 8 5/8' hole from $7305^{\prime}$ to $7400^{\prime}$. Circulated for Core \#32.

9-16-64 Cored from $7400^{\prime}$ to $7408^{\prime}$ with $8^{\prime}$ of recovery. Ran junk basket on top of bit and drilled from $7408^{\prime}$ to $7428^{\prime}$.

9-17-64 Drilled $85 / 8^{\prime \prime}$ hole from $7428^{\prime}$ to $7543^{\prime}$.

9-18-64 Made a trip for bit. Drilled $85 / 8^{\prime \prime}$ hole from $7543^{\prime}$ to $7595^{\prime}$.

9-19-64 Drilled $85 / 8^{\prime \prime}$ hole from $7595^{\prime}$ to $7674^{\prime}$.

9-20-64 Worked on draw works. Drilled $85 / 8^{\prime \prime}$ hole form $7674^{\prime}$ to $7712^{\prime}$.

9-21-64 Drilled $85 / 8^{\prime \prime}$ hole from $7712^{\prime}$ to $7800^{\prime}$. Circulated for core.

9-22-64 Cored from $7800^{\prime}$ to $7801.5^{\prime}$. Drilled $85 / 8^{\prime \prime}$ hole form $7801.5^{\prime}$ to $7840^{\prime}$.

9-23-64 Drilled $85 / 8^{\prime \prime}$ hole from $7840^{\prime}$ to $7926^{\prime}$. Made a trip for bit.

9-24-64 Finished trip for bit. Drilled $85 / 8^{\prime \prime}$ hole from $7926^{\prime}$ to $7939^{\prime}$. Cored from $7939^{\prime}$ to $7942^{\prime}$ with 3' recovery.

9-25-64 Ran temperature, continuous velocity log, electric log, density log. Had trouble with density log tool. Ran caliper lot to $7945^{\prime}$ Birdwell depth.

9-26-64 Ran density log. Ran Sperry Sun. 
Well History Pahute Mesa Exploratory Hole \#2

Page -7-

9-27-64 Filled pipe with mud. Circulating same from bottom of casing to surface. No bridges or fill. Drilled $85 / 8^{\prime \prime}$ hole form $7942^{\prime}$ to $8020^{\prime}$. Made trip for bit.

9-28-64 Drilled $85 / 8^{\prime \prime}$ hole from $8020^{\prime}$ to $8045^{\prime}$. Cored from $8045^{\prime}$ to $8053^{\prime}$ with $8^{\prime}$ recovery. Pipe stuck while coring. Worked pipe loose.

9-29-64 Drilled $85 / 8^{\prime \prime}$ hole from $8053^{\prime}$ to $8062^{\prime}$. Tripped for bit. Drilled $85 / 8^{\prime \prime}$ hole from $8062^{\prime}$ to $8095^{\prime}$.

9-30-64 Drilled $85 / 8^{\prime \prime}$ hole from $8095^{\prime}$ to $8151^{\prime}$. Made trip to change bits. Drilled from $8151^{\prime}$ to $8173^{\prime}$.

10-1-64 Drilled $85 / 8^{\prime \prime}$ hole from $8173^{\prime}$ to $8273^{\prime}$.

$10-2-64$ Cored from $8273^{\prime}$ to $8281^{\prime}$ with $7^{\prime}$ of recovery. Drilled $85 / 8^{\prime \prime}$ hole from $8281^{\prime}$ to $8300^{\prime}$.

10-3-64 Drilled $85 / 8^{\prime \prime}$ hole from $8300^{\prime}$ to $8400^{\prime}$. Circulated for core.

10-4-64 Cored from $8400^{\prime}$ to $8408^{\prime}$ with $8^{\prime}$ recovery. Drilled $85 / 8^{\prime \prime}$ hole from $8408^{\prime}$ to $8419^{\prime}$.

10-5-64 Drilled $85 / 8^{\prime \prime}$ hole from $8419^{\prime}$ to $8505^{\prime}$.

10-6-64 Drilled $85 / 8^{\prime \prime}$ hole from $8505^{\prime}$ to $8542^{\prime}$. Cored from $8542^{\prime}$ to $8545.5^{\prime}$ with $3.5^{\prime}$ recovery.

10-7-64 Laid down core barrel. Drilled $85 / 8^{\prime \prime}$ hole from $8545^{\prime}$ to $8629^{\prime}$.

10-8-64 Drilled $85 / 8^{\prime \prime}$ hole from $8629^{\prime}$ to $8728^{\prime}$.

10-9-64 Drilled $85 / 8^{\prime \prime}$ hole from $8728^{\prime}$ to $8775^{\prime}$. Cored from $8775^{\prime}$ to $8782^{\prime}$ with $7^{\prime}$ recovery.

10-10-64 W.O.O. Ran temperature and electric logs.

10-11-64 Finished running electric log. Ran 3-D, velocity and density logs. Ran caliper log to $8776^{\prime}$.

10-12-64 Ran Sperry Sun Gyro Survey. Laid down drill collars and drill pipe.

10-13-64 Laid down drill pipe and drill collars. Jetted pits. Rig released at $0500 \mathrm{hrs}$. Hole completed 10-13-64.

The Sperry Sun tool could not get below $6450^{\prime}$. From this point to the T.D. recorded Totco Surveys show the deviation. The direction was not recorded.

TOTCO DEVIATION SURVEYS

$\underline{\text { DEPTH }}$

$\underline{6800^{\prime}}$

$\underline{7029^{\prime}}$

7129'

$\underline{7228^{\prime}}$

7400'

7543'

$\underline{7650^{\prime}}$

\section{DEVIATION}

$33 / 4^{\circ}$

$41 / 2^{\circ}$

$\underline{4}^{\circ}$

31/4

$13 / 4^{\circ}$

$13 / 4^{\circ}$

$\underline{3}^{\circ}$ 
TOTCO DEVIATION SURVEYS

\section{DEPTH}

$\frac{\frac{7800^{\prime}}{7926^{\prime}}}{\frac{8020^{\prime}}{8150^{\prime}}}$

\section{DEVIATION}

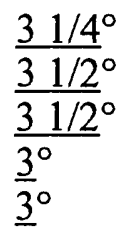

\section{SPERRY SUN MULTISHOT GYROSCOPIC SURVEYS}

\begin{tabular}{|c|c|c|c|c|}
\hline Date & $\underline{\mathrm{MD}}$ & $\underline{\text { TVD }}$ & Horizontal Displacement & $\underline{\text { Reference }}$ \\
\hline $9-28-64$ & $4000^{\prime}$ & $3999.84^{\prime}$ & $16.73^{\prime}\left(\mathrm{S} 35^{\circ} 48^{\prime} \mathrm{W}\right)$ & 151-SH-267 \\
\hline$-28-64$ & $4000^{\prime}$ & $3999.85^{\prime}$ & $15.01^{\prime}\left(\mathrm{S} 36^{\circ} 34^{\prime} \mathrm{W}\right)$ & 151-SH-267 \\
\hline $8-64$ & $6450^{\prime}$ & 6446.19 & $101.82^{\prime}\left(\mathrm{S} 64^{\circ} 17^{\prime} \mathrm{E}\right)$ & 151-SH-267 \\
\hline
\end{tabular}

In Run 151-SH-267

\begin{tabular}{rrrl}
\hline MD & TVD & Latitude & Departure \\
\hline $0^{\prime}$ & $100^{\prime}$ & $0^{\circ} \mathrm{N}$ & $0^{\circ} \mathrm{E}$ \\
$100^{\prime}$ & $100.00^{\prime}$ & $0.25^{\circ} \mathrm{S}$ & $0.15^{\circ} \mathrm{W}$ \\
$200^{\prime}$ & $199.99^{\prime}$ & $0.12^{\circ} \mathrm{N}$ & $0.30^{\circ} \mathrm{W}$ \\
$300^{\prime}$ & $299.99^{\prime}$ & $0.47^{\circ} \mathrm{S}$ & $0.26^{\circ} \mathrm{W}$ \\
$400^{\prime}$ & $399.98^{\prime}$ & $0.54^{\circ} \mathrm{S}$ & $0.20^{\circ} \mathrm{E}$ \\
$500^{\prime}$ & $499.98^{\prime}$ & $0.44^{\circ} \mathrm{S}$ & $0.77^{\circ} \mathrm{E}$ \\
$600^{\prime}$ & $599.98^{\prime}$ & $0.48^{\circ} \mathrm{S}$ & $1.06^{\circ} \mathrm{E}$ \\
$700^{\prime}$ & $699.98^{\prime}$ & $0.61^{\circ} \mathrm{S}$ & $1.31^{\circ} \mathrm{S}$ \\
$800^{\prime}$ & $799.98^{\prime}$ & $0.75^{\circ} \mathrm{S}$ & $1.41^{\circ} \mathrm{E}$ \\
$900^{\prime}$ & $899.98^{\prime}$ & $0.73^{\circ} \mathrm{S}$ & $1.21^{\circ} \mathrm{E}$ \\
$1000^{\prime}$ & $999.98^{\prime}$ & $0.64^{\circ} \mathrm{S}$ & $0.77^{\circ} \mathrm{E}$ \\
$1100^{\prime}$ & $1099.98^{\prime}$ & $0.45^{\circ} \mathrm{S}$ & $0.24^{\circ} \mathrm{E}$ \\
$1200^{\prime}$ & $1199.98^{\prime}$ & $0.70^{\circ} \mathrm{S}$ & $0.02^{\circ} \mathrm{E}$ \\
$1300^{\prime}$ & $1299.97^{\prime}$ & $0.81^{\circ} \mathrm{S}$ & $0.70^{\circ} \mathrm{W}$ \\
$1400^{\prime}$ & $1399.97^{\prime}$ & $0.74^{\circ} \mathrm{S}$ & $1.70^{\circ} \mathrm{W}$ \\
$1500^{\prime}$ & $1499.96^{\prime}$ & $0.75^{\circ} \mathrm{S}$ & $2.75^{\circ} \mathrm{W}$ \\
$1600^{\prime}$ & $1599.96^{\prime}$ & $1.23^{\circ} \mathrm{S}$ & $3.54^{\circ} \mathrm{W}$ \\
\hline & & &
\end{tabular}


In Run 151-SH-267

\begin{tabular}{|c|c|c|c|}
\hline MD & TVD & Latitude & Departure \\
\hline $1700^{\prime}$ & $1699.95^{\prime}$ & $1.36^{\circ} \mathrm{S}$ & $4.39^{\circ} \mathrm{W}$ \\
\hline $1800^{\prime}$ & $1799.95^{\prime}$ & $1.38^{\circ} \mathrm{S}$ & $5.32^{\circ} \mathrm{W}$ \\
\hline $1900^{\prime}$ & $1899.95^{\prime}$ & $1.35^{\circ} \mathrm{S}$ & $6.30^{\circ} \mathrm{W}$ \\
\hline $2000^{\prime}$ & $1999.94^{\prime}$ & $1.36^{\circ} \mathrm{S}$ & $7.24^{\circ} \mathrm{W}$ \\
\hline $2100^{\prime}$ & $2099.93^{\prime}$ & $1.18^{\circ} \mathrm{S}$ & $8.37^{\circ} \mathrm{W}$ \\
\hline $2200^{\prime}$ & $2199.93^{\prime}$ & $1.08^{\circ} \mathrm{S}$ & $9.05^{\circ} \mathrm{W}$ \\
\hline $2300^{\prime}$ & $2299.93^{\prime}$ & $0.89^{\circ} \mathrm{S}$ & $9.26^{\circ} \mathrm{W}$ \\
\hline $2400^{\prime}$ & $2399.93^{\prime}$ & $0.82^{\circ} \mathrm{S}$ & $9.15^{\circ} \mathrm{W}$ \\
\hline $2500^{\prime}$ & $2499.93^{\prime}$ & $1.05^{\circ} \mathrm{S}$ & $9.03^{\circ} \mathrm{W}$ \\
\hline $2600^{\prime}$ & $2599.93^{\prime}$ & $1.40^{\circ} \mathrm{S}$ & $9.12^{\circ} \mathrm{W}$ \\
\hline $2700^{\prime}$ & $2699.93^{\prime}$ & $1.68^{\circ} \mathrm{S}$ & $9.25^{\circ} \mathrm{W}$ \\
\hline $2800^{\prime}$ & $2799.93^{\prime}$ & $1.87^{\circ} \mathrm{S}$ & $9.24^{\circ} \mathrm{W}$ \\
\hline $2900^{\prime}$ & $2899.93^{\prime}$ & $2.19^{\circ} \mathrm{S}$ & $9.13^{\circ} \mathrm{W}$ \\
\hline $3000^{\prime}$ & $2999.93^{\prime}$ & $2.63^{\circ} \mathrm{S}$ & $9.11^{\circ} \mathrm{W}$ \\
\hline $3100^{\prime}$ & $3099.93^{\prime}$ & $3.21^{\circ} \mathrm{S}$ & $8.98^{\circ} \mathrm{W}$ \\
\hline $3200^{\prime}$ & $3199.92^{\prime}$ & $3.91^{\circ} \mathrm{S}$ & $8.77^{\circ} \mathrm{W}$ \\
\hline $3300^{\prime}$ & $3299.92^{\prime}$ & $4.75^{\circ} \mathrm{S}$ & $8.41^{\circ} \mathrm{W}$ \\
\hline $3400^{\prime}$ & $3399.92^{\prime}$ & $5.44^{\circ} \mathrm{S}$ & $8.01^{\circ} \mathrm{W}$ \\
\hline $3500^{\prime}$ & $3499.91^{\prime}$ & $6.29^{\circ} \mathrm{S}$ & $7.53^{\circ} \mathrm{W}$ \\
\hline $3600^{\prime}$ & $3599.90^{\prime}$ & $7.54^{\circ} \mathrm{S}$ & $7.03^{\circ} \mathrm{W}$ \\
\hline $3700^{\prime}$ & $3699.89^{\prime}$ & $8.80^{\circ} \mathrm{S}$ & $6.92^{\circ} \mathrm{W}$ \\
\hline $3800^{\prime}$ & $3799.88^{\prime}$ & $10.53^{\circ} \mathrm{S}$ & $7.17^{\circ} \mathrm{W}$ \\
\hline $3900^{\prime}$ & $3899.86^{\prime}$ & $12.15^{\circ} \mathrm{S}$ & $8.19^{\circ} \mathrm{W}$ \\
\hline $4000^{\prime}$ & $3999.84^{\prime}$ & $13.57^{\circ} \mathrm{S}$ & $9.79^{\circ} \mathrm{W}$ \\
\hline $4100^{\prime}$ & $4099.83^{\prime}$ & $14.39^{\circ} \mathrm{S}$ & $11.18^{\circ} \mathrm{W}$ \\
\hline $4200^{\prime}$ & $4199.82^{\prime}$ & $15.51^{\circ} \mathrm{S}$ & $12.15^{\circ} \mathrm{W}$ \\
\hline $4300^{\prime}$ & $4299.81^{\prime}$ & $16.41^{\circ} \mathrm{S}$ & $12.81^{\circ} \mathrm{W}$ \\
\hline $4400^{\prime}$ & $4399.79^{\prime}$ & $17.95^{\circ} \mathrm{S}$ & $12.01^{\circ} \mathrm{W}$ \\
\hline $4500^{\prime}$ & $4499.73^{\prime}$ & $20.76^{\circ} \mathrm{S}$ & $10.19^{\circ} \mathrm{W}$ \\
\hline $4600^{\prime}$ & $4599.67^{\prime}$ & $23.74^{\circ} \mathrm{S}$ & $8.15^{\circ} \mathrm{W}$ \\
\hline $4700^{\prime}$ & $4699.56^{\prime}$ & $27.12^{\circ} \mathrm{S}$ & $4.95^{\circ} \mathrm{W}$ \\
\hline
\end{tabular}


In Run 151-SH-267

\begin{tabular}{llll}
\hline MD & TVD & Latitude & Departure \\
\hline $4800^{\prime}$ & $4799.42^{\prime}$ & $27.54^{\circ} \mathrm{S}$ & $1.20^{\circ} \mathrm{W}$ \\
$4900^{\prime}$ & $4899.31^{\prime}$ & $30.92^{\circ} \mathrm{S}$ & $2.06^{\circ} \mathrm{E}$ \\
$5000^{\prime}$ & $4999.18^{\prime}$ & $34.37^{\circ} \mathrm{S}$ & $5.64^{\circ} \mathrm{E}$ \\
$5100^{\prime}$ & $5099.08^{\prime}$ & $37.51^{\circ} \mathrm{S}$ & $8.96^{\circ} \mathrm{E}$ \\
$5200^{\prime}$ & $5198.91^{\prime}$ & $40.68^{\circ} \mathrm{S}$ & $13.80^{\circ} \mathrm{E}$ \\
$5300^{\prime}$ & $5298.66^{\prime}$ & $44.03^{\circ} \mathrm{S}$ & $19.91^{\circ} \mathrm{E}$ \\
$5400^{\prime}$ & $5398.41^{\prime}$ & $45.98^{\circ} \mathrm{S}$ & $26.68^{\circ} \mathrm{E}$ \\
$5500^{\prime}$ & $5498.16^{\prime}$ & $48.53^{\circ} \mathrm{S}$ & $33.30^{\circ} \mathrm{E}$ \\
$5600^{\prime}$ & $5597.98^{\prime}$ & $49.68^{\circ} \mathrm{S}$ & $39.22^{\circ} \mathrm{E}$ \\
$5700^{\prime}$ & $5697.76^{\prime}$ & $49.56^{\circ} \mathrm{S}$ & $45.78^{\circ} \mathrm{E}$ \\
$5800^{\prime}$ & $5797.47^{\prime}$ & $48.25^{\circ} \mathrm{S}$ & $53.29^{\circ} \mathrm{E}$ \\
$5900^{\prime}$ & $5897.27^{\prime}$ & $48.12^{\circ} \mathrm{S}$ & $59.24^{\circ} \mathrm{E}$ \\
$6000^{\prime}$ & $5996.96^{\prime}$ & $46.48^{\circ} \mathrm{S}$ & $66.56^{\circ} \mathrm{E}$ \\
$6100^{\prime}$ & $6096.75^{\prime}$ & $45.11^{\circ} \mathrm{S}$ & $72.89^{\circ} \mathrm{E}$ \\
$6200^{\prime}$ & $6196.51^{\prime}$ & $43.86^{\circ} \mathrm{S}$ & $79.77^{\circ} \mathrm{E}$ \\
$6300^{\prime}$ & $6296.35^{\prime}$ & $42.83^{\circ} \mathrm{S}$ & $85.16^{\circ} \mathrm{E}$ \\
$6400^{\prime}$ & $6396.25^{\prime}$ & $43.42^{\circ} \mathrm{S}$ & $89.40^{\circ} \mathrm{E}$ \\
\hline & & & \\
\hline
\end{tabular}


Well History Pahute Mesa Exploratory Hole \#2

\section{Core Data}

\begin{tabular}{|c|c|c|c|c|}
\hline Core \# & Date & Interval & Recovery & Formation \& Remarks \\
\hline 1 & $5-25-64$ & $320^{\prime}-327^{\prime}$ & $5^{\prime}$ & Welded tuff \\
\hline 2 & $5-26-64$ & $512^{\prime}-519^{\prime}$ & $0^{\prime}$ & \\
\hline 3 & $5-27-64$ & $521^{\prime}-536^{\prime}$ & $0^{\prime}$ & \\
\hline 4 & $5-28-64$ & $562^{\prime}-572^{\prime}$ & $9^{\prime}$ & Bedded tuff \\
\hline 5 & $5-28-64$ & $875^{\prime}-883^{\prime}$ & $8^{\prime}$ & Bedded tuff \\
\hline 6 & $5-29-64$ & $1085^{\prime}-1092^{\prime}$ & $5^{\prime}$ & Tuff -slightly broken \\
\hline 7 & $5-30-64$ & $1300^{\prime}-1307^{\prime}$ & $6^{\prime}$ & Tuff \\
\hline 8 & $5-30-64$ & $1510^{\prime}-1517^{\prime}$ & $7^{\prime}$ & Zeolitized tuff \\
\hline 9 & $6-1-64$ & $1800^{\prime}-1807^{\prime}$ & $7^{\prime}$ & Zeolitized tuff \\
\hline 10 & $6-2-64$ & $2100^{\prime}-2108^{\prime}$ & $8^{\prime}$ & Zeolitized tuff \\
\hline 11 & $6-3-64$ & $2400^{\prime}-2407^{\prime}$ & $7^{\prime}$ & Zeolitized tuff \\
\hline 12 & $6-4-64$ & $2500^{\prime}-2507^{\prime}$ & $6^{\prime}$ & Welded tuff \\
\hline 13 & $6-11-64$ & $2700^{\prime}-2707^{\prime}$ & $7^{\prime}$ & Tuff breccia - fractured \\
\hline 14 & $6-11-64$ & $2952^{\prime}-2959^{\prime}$ & $7^{\prime}$ & Dacite \\
\hline 15 & $6-12-64$ & $3190^{\prime}-3196^{\prime}$ & $6^{\prime}$ & Dacite - fractured \\
\hline 16 & $6-13-64$ & $3447^{\prime}-3449^{\prime}$ & $2^{\prime}$ & Tuff breccia -fractured \\
\hline 17 & $6-14-64$ & $3680^{\prime}-3687^{\prime}$ & $7^{\prime}$ & Tuff \\
\hline 18 & $6-15-64$ & $3900^{\prime}-3907^{\prime}$ & $7^{\prime}$ & Tuff breccia - alight fractures \\
\hline 19 & $6-16-64$ & $4100^{\prime}-4107^{\prime}$ & $4^{\prime}$ & Tuffaceous mudstone - very broken \\
\hline 20 & $6-17-64$ & $4175^{\prime}-4282^{\prime}$ & $7^{\prime}$ & Tuffaceous mudstone \\
\hline 21 & $6-20-64$ & $4322^{\prime}-4329^{\prime}$ & $7^{\prime}$ & Dacite - fractured \\
\hline 22 & $6-22-64$ & $4530^{\prime}-4537^{\prime}$ & $7^{\prime}$ & Dacite - fractured \\
\hline 23 & $6-23-64$ & $4750^{\prime}-4757^{\prime}$ & $7^{\prime}$ & Dacite - fractured \\
\hline 24 & $6-25-64$ & $4970^{\prime}-4975^{\prime}$ & $5^{\prime}$ & Rhyodacite - slight fractures \\
\hline 25 & $6-28-64$ & $5202^{\prime}-5204^{\prime}$ & $2^{\prime}$ & Rhyodacite - highly fractured \\
\hline 26 & $6-30-64$ & $5550^{\prime}-5557^{\prime}$ & $5^{\prime}$ & Rhyodacite - highly fractured \\
\hline 27 & $7-1-64$ & $5786^{\prime}-5792^{\prime}$ & $5^{\prime}$ & Rhyodacite - highly fractured \\
\hline 28 & $7-2-64$ & $5892^{\prime}-5899^{\prime}$ & $7^{\prime}$ & Latite - highly fractured \\
\hline 29 & $9-2-64$ & $6550^{\prime}-6558^{\prime}$ & $1^{\prime}$ & Dacite - fractured \\
\hline
\end{tabular}




\section{Core Data}

\begin{tabular}{ccccl}
\hline Core \# & Date & Interval & Recovery & \multicolumn{1}{c}{ Formation \& Remarks } \\
\hline 30 & $9-6-64$ & $6748^{\prime}-6753^{\prime}$ & $4^{\prime}$ & Dacite - fractured \\
31 & $9-11-64$ & $7029^{\prime}-7035^{\prime}$ & $6^{\prime}$ & Dacite - highly fractured \\
32 & $9-16-64$ & $7400^{\prime}-7408^{\prime}$ & $8^{\prime}$ & Dacite - fractured \\
33 & $9-22-64$ & $7800^{\prime}-9801.5^{\prime}$ & $1.5^{\prime}$ & Dacite - highly fractured \\
34 & $9-24-64$ & $7939^{\prime}-7942^{\prime}$ & $3^{\prime}$ & Dacite - fractured \\
35 & $9-28-64$ & $8045^{\prime}-8053^{\prime}$ & $8^{\prime}$ & Dacite - fractures \\
36 & $10-2-64$ & $8273^{\prime}-8281^{\prime}$ & $7^{\prime}$ & Dacite - fractures \\
37 & $10-4-64$ & $8400^{\prime}-8408^{\prime}$ & $8^{\prime}$ & Aplite breccia \\
38 & $10-7-64$ & $8542^{\prime}-8545.5^{\prime}$ & $3.5^{\prime}$ & Granodiorite \\
39 & $10-9-64$ & $8775^{\prime}-8782^{\prime}$ & $7^{\prime}$ & Granodiorite \\
\hline
\end{tabular}




\section{CEMENTING RECORD}

USER:

HOLE NO: PM EX. \#2

DATE PREPARED: 09-19-90 By JEC

CEMENTING RECORD FOR: $13-3 / 8^{\prime \prime}$ O.D. 54.5\#. 0.38" wall casing at $2492^{\prime}$ in 17-1/2" hole to $2507^{\prime}$ 20" O.D. 78.6\#. 0.375" wall casing cemented at 44'. Information taken from Hole History.

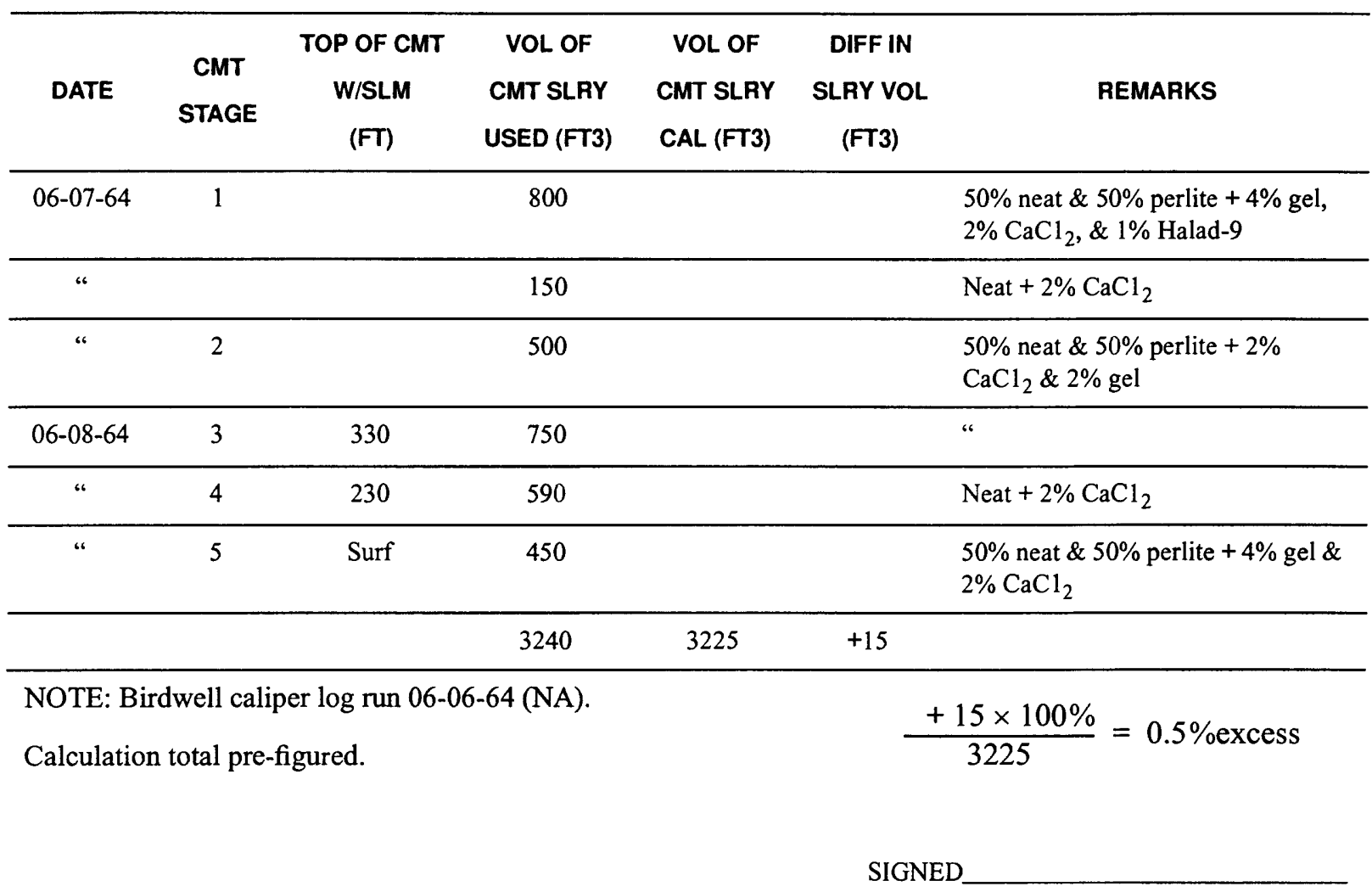




\section{CEMENTING RECORD}

USER:

HOLE NO: PM EX. \#2

DATE PREPARED: 09-19-90 By JEC

CEMENTING RECORD FOR: 9-5/8" O.D. 36\# Casing at $3676^{\prime}$ and $40 \#$ casing to $5498^{\prime}$ and DV tool at $510^{\prime}$ with metal petal at 540' IN 12-1/4" HOLE TO 5500', 12.615" I.D. casing cemented at 2492'.

Information taken from hole history.

\begin{tabular}{|c|c|c|c|c|c|c|c|}
\hline DATE & $\begin{array}{l}\text { CMT } \\
\text { STAGE }\end{array}$ & $\begin{array}{l}\text { TOP OF } \\
\text { CMT } \\
\text { W/- } \\
(\mathrm{FT})\end{array}$ & $\begin{array}{l}\text { CMT RISE } \\
\text { (FT) }\end{array}$ & $\begin{array}{c}\text { VOL OF } \\
\text { CMT } \\
\text { SLRY } \\
\text { USED } \\
\text { (FT3) }\end{array}$ & $\begin{array}{c}\text { VOL OF } \\
\text { CMT } \\
\text { SLRY } \\
\text { CAL (FT3) }\end{array}$ & $\begin{array}{l}\text { DIFF IN } \\
\text { SLRY } \\
\text { VOL } \\
\text { (FT3) }\end{array}$ & REMARKS \\
\hline $08-10-64$ & 1 & & & 350 & & & $\begin{array}{l}\text { Neat }+12-1 / 4^{\#} \text { gilsonite } / 5 x, 4 \% \\
\text { gel, } 1 \% \text { FLAC, \& } 0.2 \% \text { D-8 }\end{array}$ \\
\hline “ & & 4145 & 1355 & 150 & 470 & +30 & Neat $+1 \%$ FLAC \& $0.2 \%$ D- 8 \\
\hline \multirow[t]{2}{*}{ “ } & 2 & Surf & $540^{\prime}$ & 360 & 197 & +163 & Neat $+2 \% \mathrm{CaCl}_{2}$ \\
\hline & & & & 860 & 667 & +193 & \\
\hline
\end{tabular}

NOTE: Birdwell caliper log run 08-08-64 (NA).

$$
\frac{+193 \times 100 \%}{667}=29 \% \text { excess }
$$

Calculations based on 12.5" gauge hole

$$
\begin{aligned}
& \text { 12.5" O.H. }=0.8522 \mathrm{ft}^{2} \\
& \text { 12.615" I.D }=0.8694 \mathrm{ft}^{2} \\
& \text { 9-5/8" O.D. }=0.5053 \mathrm{ft}^{2}
\end{aligned}
$$

SIGNED 


\section{APPENDIX B. Geophysical Logs Available for Well PM-2}

The information contained in Appendix B was provided by Raytheon Services Nevada (formerly Fenix \& Scisson). It is presented in the format provided to the USGS . 
Original 6-30-65

Revision 9-30-66

Revision \#2 8-18-67
HOLE No.

USGS Exploratory

Pahute Mesa \#2

\begin{tabular}{|c|c|c|c|c|c|c|c|}
\hline \multirow{2}{*}{ TYPE } & \multirow{2}{*}{ DATE } & \multirow{2}{*}{$\begin{array}{l}\text { RUN } \\
\text { NO. }\end{array}$} & \multicolumn{2}{|c|}{ TOTAL DEPTH } & \multicolumn{2}{|c|}{ LOGGED INTERVAL } & \multirow{2}{*}{ REMARKS } \\
\hline & & & DRILLERS & LOGGERS & FROM & TO & \\
\hline Caliper & $6-6-64$ & 1 & $2496^{\prime}$ & $2470^{\prime}$ & $64^{\prime}$ & $2469^{\prime}$ & \\
\hline Caliper & $7-11-64$ & 2 & $6080^{\prime}$ & $3983^{\prime}$ & $2400^{\prime}$ & $3983^{\prime}$ & \\
\hline Caliper & $8-8-64$ & 3 & $5500^{\prime}$ & $5500^{\prime}$ & $2450^{\prime}$ & $5499^{\prime}$ & \\
\hline Caliper & $8-19-64$ & 4 & $6180^{\prime}$ & $5817^{\prime}$ & $5450^{\prime}$ & $5816^{\prime}$ & \\
\hline Caliper & $8-20-64$ & 5 & $6180^{\prime}$ & $5801^{\prime}$ & $5450^{\prime}$ & $5800^{\prime}$ & \\
\hline Caliper & $9-25-64$ & & $7942^{\prime}$ & $7945^{\prime}$ & $5490^{\prime}$ & $7940^{\prime}$ & \\
\hline Caliper & $10-11-64$ & 2 & $8781^{\prime}$ & $8776^{\prime}$ & $7000^{\prime}$ & $8775^{\prime}$ & \\
\hline Electric & $6-6-64$ & 1 & $2496^{\prime}$ & $2453^{\prime}$ & $1060^{\prime}$ & $2453^{\prime}$ & \\
\hline Electric & $7-10-64$ & 2 & $6080^{\prime}$ & $4074^{\prime}$ & $2484^{\prime}$ & $4074^{\prime}$ & \\
\hline Electric & $7-10-64$ & 3 & $6080^{\prime}$ & $4074^{\prime}$ & $2484^{\prime}$ & $4074^{\prime}$ & \\
\hline Electric & $8-9-64$ & 4 & $5500^{\prime}$ & $5500^{\prime}$ & $2484^{\prime}$ & $5498^{\prime}$ & \\
\hline Electric & $8-9-64$ & 5 & $5500^{\prime}$ & $5500^{\prime}$ & $2484^{\prime}$ & $5498^{\prime}$ & \\
\hline Electric & $9-25-64$ & 1 & $7942^{\prime}$ & $7945^{\prime}$ & $5500^{\prime}$ & $7945^{\prime}$ & \\
\hline Electric & $10-11-64$ & 2 & $8781^{\prime}$ & $8775^{\prime}$ & $7000^{\prime}$ & $8775^{\prime}$ & \\
\hline Radio Active & $7-11-64$ & 1 & $6080^{\prime}$ & & $2300^{\prime}$ & $3980^{\prime}$ & \\
\hline Radio Active & $9-25-64$ & 1 & $7942^{\prime}$ & $7945^{\prime}$ & $5500^{\prime}$ & $7945^{\prime}$ & \\
\hline Salinometer & $7-11-64$ & $1 \& 2$ & $6080^{\prime}$ & $4074^{\prime}$ & $850^{\prime}$ & $4074^{\prime}$ & \\
\hline Salinometer & $7-11-64$ & 3 & $6080^{\prime}$ & $3983^{\prime}$ & $850^{\prime}$ & $3983^{\prime}$ & \\
\hline Density & $6-5-64$ & 1 & $2496^{\prime}$ & $2473^{\prime}$ & $0^{\prime}$ & $2470^{\prime}$ & \\
\hline Density & $7-11-64$ & 2 & $6080^{\prime}$ & $3983^{\prime}$ & $2450^{\prime}$ & $3983^{\prime}$ & \\
\hline Density & $8-8-64$ & 3 & $5500^{\prime}$ & $5497^{\prime}$ & $3800^{\prime}$ & $5492^{\prime}$ & \\
\hline Density & $9-25-64$ & 1 & $7942^{\prime}$ & $7945^{\prime}$ & $5500^{\prime}$ & $7945^{\prime}$ & \\
\hline Density & $10-10-64$ & 2 & $8781^{\prime}$ & $8778^{\prime}$ & $7000^{\prime}$ & $8775^{\prime}$ & \\
\hline Pressure Finder & $9-25-64$ & 1 & $7942^{\prime}$ & $7945^{\prime}$ & $5400^{\prime}$ & $7940^{\prime}$ & MSG \\
\hline $3-D$ & $7-10-64$ & 1 & $6080^{\prime}$ & $4076^{\prime}$ & $2450^{\prime}$ & $4072^{\prime}$ & \\
\hline 3-D & $7-10-64$ & 2 & $6080^{\prime}$ & $4076^{\prime}$ & $2450^{\prime}$ & $4068^{\prime}$ & \\
\hline $3-D$ & $8-8-64$ & 3 & $5500^{\prime}$ & $5490^{\prime}$ & $3800^{\prime}$ & $5488^{\prime}$ & \\
\hline 3-D & $8-8-64$ & 4 & $5500^{\prime}$ & $5500^{\prime}$ & $3800^{\prime}$ & $5490^{\prime}$ & \\
\hline Velocity & $7-11-64$ & 2 & $6080^{\prime}$ & $4074^{\prime}$ & $2450^{\prime}$ & $4070^{\prime}$ & \\
\hline
\end{tabular}




\begin{tabular}{|c|c|c|c|c|c|c|c|}
\hline \multirow{2}{*}{ TYPE } & \multirow{2}{*}{ DATE } & \multirow{2}{*}{$\begin{array}{l}\text { RUN } \\
\text { No. }\end{array}$} & \multicolumn{2}{|c|}{ TOTAL DEPTH } & \multicolumn{2}{|c|}{ LOGGED INTERVAL } & \multirow{2}{*}{ REMARKS } \\
\hline & & & DRILLERS & LOGGERS & FROM & TO & \\
\hline Velocity & $8-9-64$ & 2 & $5500^{\prime}$ & $5500^{\prime}$ & $3100^{\prime}$ & $5495^{\prime}$ & \\
\hline Velocity & $9-25-64$ & 1 & $7942^{\prime}$ & $7945^{\prime}$ & $5470^{\prime}$ & $7938^{\prime}$ & \\
\hline Velocity & $10-11-64$ & 2 & $8781^{\prime}$ & $8777^{\prime}$ & $7000^{\prime}$ & $8772^{\prime}$ & \\
\hline Temp & $6-6-64$ & 1 & $2496^{\prime}$ & $2470^{\prime}$ & $0^{\prime}$ & $2470^{\prime}$ & \\
\hline Temp & $6-7-64$ & 2 & $2473^{\prime}$ & & $0^{\prime}$ & $2150^{\prime}$ & \\
\hline Temp & $7-10-64$ & 3 & $6080^{\prime}$ & $4076^{\prime}$ & $0^{\prime}$ & $4076^{\prime}$ & \\
\hline Temp & $7-11-64$ & 4 & $6080^{\prime}$ & $3983^{\prime}$ & $0^{\prime}$ & $3983^{\prime}$ & \\
\hline Temp & $8-2-64$ & 1 & $5500^{\prime}$ & $5498^{\prime}$ & $3800^{\prime}$ & $5498^{\prime}$ & \\
\hline Temp & $8-7-64$ & 5 & $5500^{\prime}$ & $5498^{\prime}$ & $3800^{\prime}$ & $5498^{\prime}$ & \\
\hline Temp & $8-10-64$ & 6 & $5500^{\prime}$ & $5438^{\prime}$ & $0^{\prime}$ & $5438^{\prime}$ & \\
\hline Temp & $9-25-64$ & & $7942^{\prime}$ & $7950^{\prime}$ & $0^{\prime}$ & $7950^{\prime}$ & \\
\hline Temp & $10-10-64$ & 2 & $8781^{\prime}$ & $8780^{\prime}$ & $7000^{\prime}$ & $8780^{\prime}$ & \\
\hline E.C.C. & $5-29-65$ & & & & $5492^{\prime}$ & $8768^{\prime}$ & \\
\hline $\begin{array}{l}\text { Gamma Ray } \\
\text { Neutron }\end{array}$ & $4-27-66$ & 1 & N/A & N/A & $3150^{\prime}$ & $3650^{\prime}$ & \\
\hline Water Locator & $6-6-66$ & 1 & N/A & N/A & $1010^{\prime}$ & $1066^{\prime}$ & \\
\hline Water Locator & $8-16-66$ & 2 & N/A & N/A & $900^{\prime}$ & $974^{\prime}$ & $961^{\prime}$ \\
\hline Water Locator & $4-12-67$ & 3 & N/A & $\begin{array}{r}\text { Not } \\
\text { Reached }\end{array}$ & $850^{\prime}$ & $950^{\prime}$ & Fluid Level $895^{\prime}$ \\
\hline Gyro & $9-26-64$ & & & & $0^{\prime}$ & $6450^{\prime}$ & 151-SH-267 \\
\hline WL & $11-21-67$ & 4 & NA & $\begin{array}{r}\text { Not } \\
\text { Reached }\end{array}$ & $850^{\prime}$ & 896 & \\
\hline Caliper & $11-5-68$ & 6 & $8775^{\prime}$ & Ditto & $0^{\prime}$ & $1000^{\prime}$ & \\
\hline CCL & $11-5-68$ & 1 & $8775^{\prime}$ & Ditto & $0^{\prime}$ & $1000^{\prime}$ & \\
\hline FLD & $11-5-68$ & 1 & $8775^{\prime}$ & Ditto & $864^{\prime}$ & $2000^{\prime}$ & \\
\hline Caliper & $11-8-68$ & 7 & $8782^{\prime}$ & Ditto & $0^{\prime}$ & $1000^{\prime}$ & \\
\hline $\mathrm{CCL}$ & $11-8-68$ & 2 & $8782^{\prime}$ & Ditto & $0^{\prime}$ & $1000^{\prime}$ & \\
\hline Caliper & $6-6-69$ & 8 & $8782^{\prime}$ & Ditto & $0^{\prime}$ & $1000^{\prime}$ & \\
\hline CCL & $6-6-69$ & 3 & $8782^{\prime}$ & Ditto & $0^{\prime}$ & $1000^{\prime}$ & \\
\hline WL & $6-6-69$ & 5 & $8782^{\prime}$ & Ditto & $850^{\prime}$ & $900^{\prime}$ & \\
\hline FF & $10-11-64$ & 2 & $8782^{\prime}$ & $8775^{\prime}$ & $7000^{\prime}$ & $8770^{\prime}$ & Welex \\
\hline Depth Ck & $6-20-83$ & & $8781^{\prime}$ & $3066^{\prime}$ & & $3066^{\prime}$ & \\
\hline Thermal & $10-19-83$ & & $8782^{\prime}$ & $2721^{\prime}$ & $0^{\prime}$ & $2721^{\prime}$ & \\
\hline
\end{tabular}




\begin{tabular}{|l|l|l|c|c|c|c|c|}
\hline \multirow{2}{*}{ TYPE } & \multirow{2}{*}{ DATE } & \multirow{2}{*}{$\begin{array}{c}\text { RUN } \\
\text { NO. }\end{array}$} & \multicolumn{2}{c|}{ TOTAL DEPTH } & \multicolumn{2}{c|}{ LOGGED INTERVAL } & \multirow{2}{*}{ REMARKS } \\
\cline { 5 - 8 } & & & DRILLERS & LOGGERS & FROM & TO & \\
\hline Neutron & $10-19-83$ & & $8782^{\prime}$ & $2721^{\prime}$ & $0^{\prime}$ & $2721^{\prime}$ & \\
\hline Temp & $10-19-83$ & & $8782^{\prime}$ & $2721^{\prime}$ & $0^{\prime}$ & $2721^{\prime}$ & \\
\hline Gamma & $10-19-83$ & & $8782^{\prime}$ & $2721^{\prime}$ & $0^{\prime}$ & $2721^{\prime}$ & \\
\hline K.U.T. & $10-20-83$ & & $8782^{\prime}$ & $3066^{\prime}$ & $0^{\prime}$ & $3066^{\prime}$ & \\
\hline Gamma Ray & $10-20-83$ & & $8782^{\prime}$ & $3066^{\prime}$ & $0^{\prime}$ & $3059^{\prime}$ & \\
\hline K.U.T. & $10-21-83$ & & $8782^{\prime}$ & $3062^{\prime}$ & $1600^{\prime}$ & $3059^{\prime}$ & Fluid Level 2215' \\
\hline T. L. & $10-21-83$ & & $8782^{\prime}$ & $3062^{\prime}$ & $1600^{\prime}$ & $3059^{\prime}$ & \\
\hline Caliper & $10-21-83$ & & $8782^{\prime}$ & $3062^{\prime}$ & $1600^{\prime}$ & $3059^{\prime}$ & \\
\hline E.P.N. & $10-21-83$ & & $8782^{\prime}$ & $3065^{\prime}$ & $8^{\prime}$ & $3059^{\prime}$ & \\
\hline Gamma Ray & $10-21-83$ & & $8782^{\prime}$ & $3065^{\prime}$ & $8^{\prime}$ & $3059^{\prime}$ & \\
\hline
\end{tabular}




\section{APPENDIX C. Summary of Soil-Sampling Surveys at Well PM-2}

The information contained in Appendix C was provided by Reynolds Electrical \& Engineering Co., Inc. It is presented in the format provided to the USGS. 


\title{
Reynolds Electrical \& Engineering Co., Inc.
}

\author{
MEMORANDUM \\ To \\ F. D. Ferate \\ From \\ A. R. Latham \\ January $13 ; 1994$ \\ Subject \\ ANALYTXCAL REPORT ON TRITIUM, SOIL MOISTURE, AND GAMMA \\ ANALYSES OF THE PM-2 WELLHEAD SOIL SAMPLES
}

Enclosed are Analytical Services Department's results for tritium, moisture content, and gamma analyses of 12 PM-2 wellhead soil samples submitted for analysis on November 22, 1993. Tritium and gamma results are in the units of micro-Curies per gram of soil as submitted ( $i . e$. wet weight).

This report contains results for the following samples:

\begin{tabular}{llllll}
\multicolumn{1}{c}{ Client Sample ID } & Lab ID & & Client Sample ID & Lab ID \\
\cline { 1 - 2 } WELL PM-2 A-SURFACE & 80227 & & WELL PM-2 D-SURFACE & 80990 \\
WELL PM-2 A-30-CM & 80980 & & WELL PM-2 D-30-CM & 80992 \\
WELL PM-2 B-SURFACE & 80982 & & WELL PM-2 E-SURFACE & 80994 \\
WELL PM-2 B-30-CM & 80984 & & WELL PM-2 E-30-CM & 80996 \\
WELL PM-2 C-SURFACE & 80986 & & WELL PM-2 F-SURFACE & 80998 \\
WELL PM-2 C-30-CM & 80988 & WELL PM-2 F-30-CM & 81000
\end{tabular}

\section{QUALITY CONTROL}

Background and laboratory control samples were analyzed for tritium and gamma with the samples listed above. Results are included in this report.

Please direct any questions you may have to $Y$. K. Lee at 295-7075.

Enclosures

As stated

$A R L: Y K L: 181: V B$

cy: Central Files, w/encls., M/S 530

L. S. Sygitowicz $w / 0$ encls., M/S 708

\section{$\therefore \therefore .2 \sin 3$}

ouln'SOSn 


\section{SOIL MOISTURE OF PM-2 WELLHEAD SOIL SAMPLES}

Reported to: F. D. Ferate

Packet Nos: $\underline{05089 \& 05090}$

Report Date: Jan. 12, 1994
Program No: 113 Analys is Date: Nov. 25, 1993

\begin{tabular}{llc}
\multicolumn{1}{c}{ Client Sample ID } & Lab ID & MOISTURE BY WT. \\
\cline { 1 - 1 } WELL PM-2 A-SURFACE & 80979 & \\
WELL PM-2 A-30-CM & 80981 & 2.6 \\
WELL PM-2 B-SURFACE & 80983 & 4.9 \\
WELL PM-2 B-30-CM & 80985 & 1.2 \\
WELL PM-2 C-SURFACE & 80987 & 1.3 \\
WELL PM-2 C-30-CM & 80989 & 1.1 \\
WELL PM-2 D-SURFACE & 80991 & 25.0 \\
WELL PM-2 D-30-CM & 80993 & 1.9 \\
WELL PM-2 E-SURFACE & 80995 & 1.7 \\
WELL PM-2 E-30-CM & 80997 & 2.9 \\
WELL PM-2 F-SURFACE & 80999 & 5.8 \\
WELL PM-2 F-30-CM & 81001 & 1.8 \\
\end{tabular}

a In units of grams of moisture per 100 grams of soil as submitted.

b The physical appearance of Sample WELL PM-2 C-30-CM is quite difference as compared with other soil samples in this batch. It has a much lighter color and much lower density. Reanalysis of the sample on January 12, 1993 confirmed the relatively high amount of moisture content.

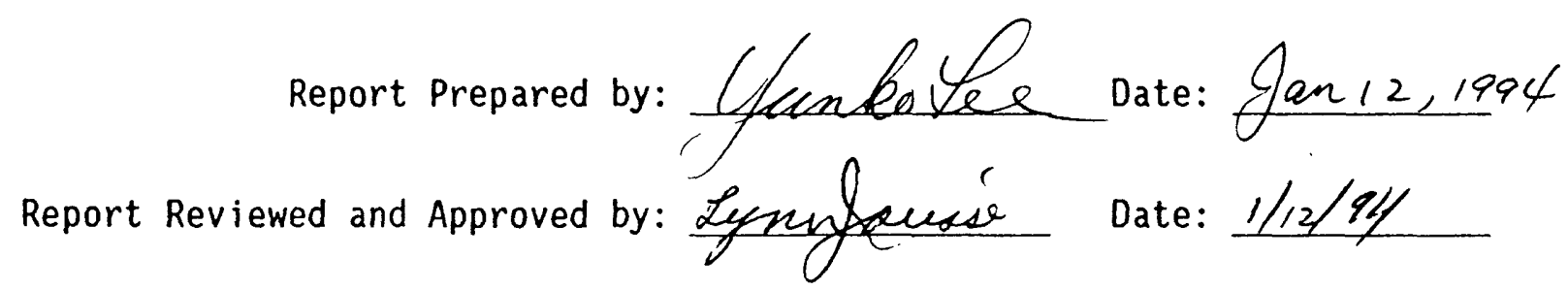




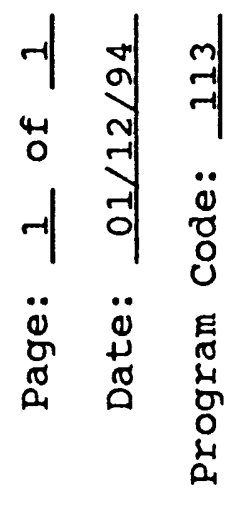

告

\begin{tabular}{|c|c|c|c|c|}
\hline 뜸음 & $\stackrel{\infty}{\circ}$ & $\stackrel{\sim}{\sim}$ & $\stackrel{n}{\sim}$ & $\stackrel{\infty}{\circ}$ \\
\hline 岩崖 & 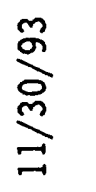 & $\underset{\approx}{\stackrel{m}{⿰}}$ & $\underset{\stackrel{m}{\sigma}}{\stackrel{m}{\approx}}$ & 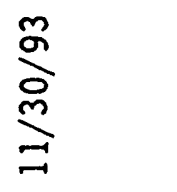 \\
\hline 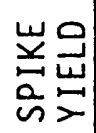 & $\stackrel{a}{z}$ & ஓ̊ & 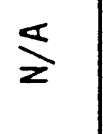 & 今̊ํㅇ웡ㅁㅇ \\
\hline$\stackrel{n}{\stackrel{n}{\Xi}}$ & $\frac{\sigma}{z}$ & $\frac{\sigma}{\bar{z}}$ & $\overbrace{\bar{z}}^{\sigma}$ & 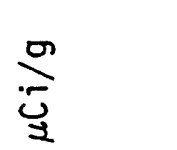 \\
\hline 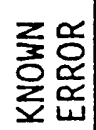 & $\lesssim$ & ○̊ & 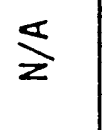 & 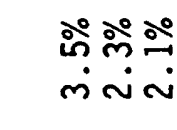 \\
\hline 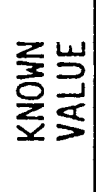 & 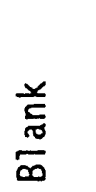 & 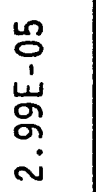 & $\frac{x}{\frac{D}{c}}$ & 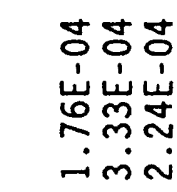 \\
\hline 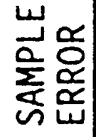 & $\frac{\alpha}{z}$ & సे & 今̊̊̊ & $\begin{array}{l}\text { స̊ స̊ స̊ } \\
\text { ஸे }\end{array}$ \\
\hline 崩 & 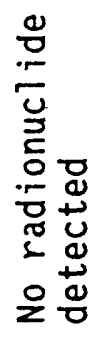 & $\begin{array}{l}\text { L } \\
0 \\
1 \\
w \\
\infty \\
\infty \\
\sim \\
\sim\end{array}$ & $\begin{array}{l}\infty \\
0 \\
1 \\
\dot{g} \\
0 \\
\dot{0}\end{array}$ & 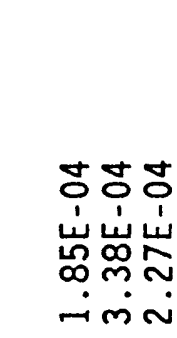 \\
\hline 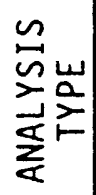 & 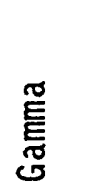 & 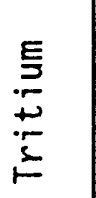 & 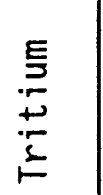 & 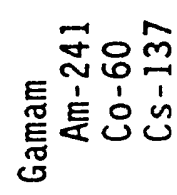 \\
\hline 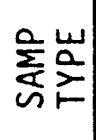 & $\begin{array}{l}\text { 离志 } \\
\text { 至品 }\end{array}$ & 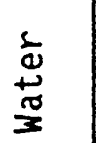 & 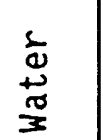 & $\overline{0}$ \\
\hline 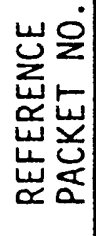 & 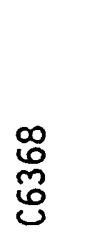 & S & $\underset{\substack{\infty \\
\frac{1}{1}}}{n}$ & 兽 \\
\hline 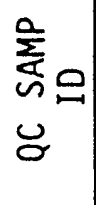 & $\begin{array}{l}\frac{x}{c} \\
\frac{\pi}{\infty} \\
\frac{m}{\delta}\end{array}$ & 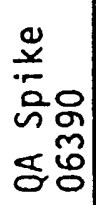 & 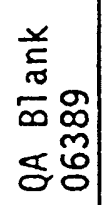 & 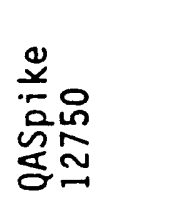 \\
\hline
\end{tabular}

| 
* * LDAS SUMMARY REPORT ON 12-JAN-94 AT 07:42:53 * *

PROJECT: RES EVENT/PROGRAM: ENVIRONMENTAL SURVEILLANCE SPECIAL STUDIES TYPE: SOIL GROSS ( $500 \mathrm{ML}$ BOTTLE)

PACKET D5089 ITEM 0

SAMPLE 80227 ID= WELL PM-2 A-SURFACE SAMPLING DATE 111993 COMMENT - H-3 MDA SHOULD BE $3 . \mathrm{E}-7 \mathrm{uCi} / \mathrm{ml}$

ANALYSIS $=\mathrm{H}-3$ TRITIUM

PARAMETER $=67861 \mathrm{SIGMA}=2.0 \mathrm{SIZE}=1.00 \mathrm{E}+01 \quad$ PROCESSED ON 122093

\begin{tabular}{|c|c|c|c|c|}
\hline 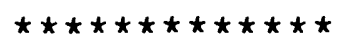 & RESULT & $\star \star *$ & $\div$ ERROR & DET LIMIT \\
\hline H- 3 TRITIUM & & $7.31 E-07$ & $3.37 E+01$ & $2.34 E-07$ \\
\hline
\end{tabular}

PACKET D5089 ITEM 0

SAMPLE 80227 ID= WELL PM-2 A-SURFACE SAMPLING DATE 111993 -

ANALYSIS $=$ GAMMA COMMENT - - H-3 MDA SHOULD BE $3 . \mathrm{E}-7 \mathrm{uCi} / \mathrm{ml}$

PARAMETER $=00816 \mathrm{SIGMA}=2.0 \mathrm{SIZE}=6.93 \mathrm{E}+02 \quad$ PROCESSED ON 113093

\begin{tabular}{|c|c|c|c|c|c|c|}
\hline$\star \star \star \star \star \star \star$ & 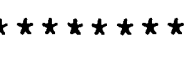 & * RESULT & 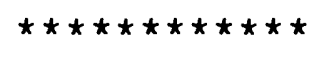 & $\frac{\circ}{6}$ ERROR & DET LIMIT & UNITS \\
\hline AM2 41 & & & $7.38 E-06$ & $1.13 E+01$ & $2.40 E-07$ & $\mathrm{uCi} / \mathrm{g}$ \\
\hline $\mathrm{CO} 60$ & & & $2.36 E-06$ & $1.15 E+01$ & $5.07 E-08$ & $\mathrm{uCi} / \mathrm{g}$ \\
\hline $\operatorname{CS} 137$ & & & $8.17 E-07$ & $1.82 \mathrm{E}+01$ & $7.06 E-08$ & $\mathrm{uCi} / \mathrm{g}$ \\
\hline EU150 & & & $6.18 E-07$ & $1.86 E+01$ & $5.84 E-08$ & $\mathrm{uCi} / \mathrm{g}$ \\
\hline EU152 & & & $7.06 E-06$ & $1.12 \mathrm{E}+01$ & $2.03 E-07$ & $\mathrm{uCi} / \mathrm{g}$ \\
\hline EU154 & & & $6.20 E-06$ & $1.19 E+01$ & $1.70 \mathrm{E}-07$ & $\mathrm{uCi} / \mathrm{g}$ \\
\hline K 40 & & & $3.71 E-05$ & $1.02 E+01$ & $3.05 E-07$ & $\mathrm{uCi} / \mathrm{g}$ \\
\hline RA226 & & & $1.02 E-06$ & $2.24 E+01$ & $1.23 E-07$ & $\mathrm{uCi} / \mathrm{g}$ \\
\hline TH228 & & & $2.38 E-06$ & $1.42 \mathrm{E}+01$ & $1.31 E-07$ & $\mathrm{uCi} / \mathrm{g}$ \\
\hline TH232 & & & $2.10 \mathrm{E}-06$ & $2.21 E+01$ & $2.56 E-07$ & $\mathrm{uCi} / \mathrm{g}$ \\
\hline XPEAK & 150.8 & Kev & $2.04 \mathrm{E}+00$ & $7.21 E+01$ & $0.00 E+00$ & $\mathrm{cpm}$ \\
\hline XPEAK & 209.4 & Kev & $1.82 E+00$ & $7.19 E+01$ & $0.00 E+00$ & $\mathrm{cpm}$ \\
\hline XPEAK & 270.5 & Kev & $1.49 E+00$ & $6.27 E+01$ & $0.00 E+00$ & $\mathrm{cpm}$ \\
\hline XPEAK & 328.3 & $\mathrm{KeV}$ & $1.10 \mathrm{E}+00$ & $8.58 E+01$ & $0.00 E+00$ & $\mathrm{cpm}$ \\
\hline XPEAK & 367.6 & Kev & $1.05 E+00$ & $7.98 E+01$ & $0.00 E+00$ & cpm \\
\hline XPEAK & 488.6 & Kev & $5.00 E-01$ & $1.18 E+02$ & $0.00 E+00$ & $\mathrm{cpm}$ \\
\hline XPEAK & 624.4 & $\mathrm{Kev}$ & $5.45 E-01$ & $1.30 \mathrm{E}+02$ & $0.00 E+00$ & $\mathrm{cpm}$ \\
\hline XPEAK & 766.3 & Kev & $9.90 E-01$ & $6.68 E+01$ & $0.00 E+00$ & cpm \\
\hline XPEAK & 846.2 & Kev & $6.35 E-01$ & $9.70 E+01$ & $0.00 E+00$ & cpm \\
\hline XPEAK & 904.6 & $\mathrm{KeV}$ & $6.05 E-01$ & $9.85 E+01$ & $0.00 E+00$ & $\mathrm{cpm}$ \\
\hline XPEAK & 934.1 & $\mathrm{Kev}$ & $4.05 E-01$ & $1.10 E+02$ & $0.00 E+00$ & $\mathrm{cpm}$ \\
\hline XPEAK & 989.2 & Kev & $4.60 E-01$ & $1.04 E+02$ & $0.00 E+00$ & $\mathrm{cpm}$ \\
\hline XPEAK & 1016.1 & $\mathrm{KeV}$ & $6.00 E-01$ & $8.79 E+01$ & $0.00 E+00$ & $\mathrm{cpm}$ \\
\hline XPEAK & 1128.7 & Kev & $8.60 E-01$ & $6.03 E+01$ & $0.00 E+00$ & cpm \\
\hline XPEAK & 1236.6 & $\mathrm{Kev}$ & $7.25 E-01$ & $6.77 E+01$ & $0.00 E+00$ & $\mathrm{cpm}$ \\
\hline XPEAK & 1378.3 & Kev & $4.60 E-01$ & $5.07 E+01$ & $0.00 \mathrm{E}+00$ & $\mathrm{cpm}$ \\
\hline XPEAK & 1399.7 & Kev & $5.75 E-01$ & $4.17 E+01$ & $0.00 E+00$ & $\mathrm{cpm}$ \\
\hline XPEAK & 1494.6 & Kev & $2.80 E-01$ & $6.58 E+01$ & $0.00 E+00$ & $\mathrm{cpm}$ \\
\hline XPEAK & 1510.2 & $\mathrm{KeV}$ & $2.10 \mathrm{E}-01$ & $9.55 E+01$ & $0.00 E+00$ & $\mathrm{cpm}$ \\
\hline XPEAK & 1529.9 & $\mathrm{Kev}$ & $3.85 E-01$ & $5.03 E+01$ & $0.00 \mathrm{E}+00$ & $\mathrm{cpm}$ \\
\hline XPEAK & 1540.4 & $\mathrm{KeV}$ & $2.45 E-01$ & $6.38 E+01$ & $0.00 E+00$ & $\mathrm{cpm}$ \\
\hline XPEAK & 1588.5 & Kev & $3.30 E-01$ & $5.75 E+01$ & $0.00 E+00$ & cpm \\
\hline XPEAK & 1597.3 & Kev & $5.95 E-01$ & $4.29 E+01$ & $0.00 E+00$ & $\mathrm{cpm}$ \\
\hline
\end{tabular}


PROJECT: RES EVENT/PROGRAM: ENVIRONMENTAL SURVEILLANCE SPECIAL STUDIES TYPE: SOIL GROSS (500 ML BOTTLE)

PACKET D5089 ITEM 0

SAMPLE 80227 ID = WELL PM-2 A-SURFACE SAMPLING DATE 111993 -

$\begin{array}{lllllll}\text { XPEAK } & 1731.0 & \mathrm{KeV} & 2.85 \mathrm{E}-01 & 4.60 \mathrm{E}+01 & 0.00 \mathrm{E}+00 & \mathrm{cpm} \\ \text { XPEAK } & 1848.3 \mathrm{KeV} & 1.45 \mathrm{E}-01 & 8.59 \mathrm{E}+01 & 0.00 \mathrm{E}+00 & \mathrm{cpm} \\ \text { XPEAK } & 1861.7 \mathrm{KeV} & 8.00 \mathrm{E}-02 & 9.41 \mathrm{E}+01 & 0.00 \mathrm{E}+00 & \mathrm{cpm}\end{array}$

ANALYSIS: H2O_SOIL H2O IN SOIL

IN PROCESS * *

PACKET D5089 ITEM 1

SAMPLE 80980 ID= WELL PM-2 A-30-CM SAMPLING DATE 111993 COMMENT - - H-3 MDA SHOULD BE 3.E-7 uCi/ml

ANALYSIS $=\mathrm{H}-3$ TRITIUM

PARAMETER $=67861$ SIGMA $=2.0$ SIZE $=1.00 E+01 \quad$ PROCESSED ON 122093

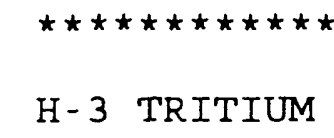
RESULT
ERROR
DET LIMIT
UNITS
$2.79 E-06$
$1.88 \mathrm{E}+01$
$4.67 \mathrm{E}-07$
$\mathrm{uCi} / \mathrm{g}$

PACKET D5089 ITEM 1

SAMPLE 80980 ID $=$ WELL PM-2 A-30-CM SAMPLING DATE 111993 -

ANALYSIS $=$ GAMMA

COMMENT - - H-3 MDA SHOULD BE 3.E-7 uCi/ml

PARAMETER $=00816 \mathrm{SIGMA}=2.0 \mathrm{SIZE}=6.30 \mathrm{E}+02 \quad$ PROCESSED ON 113093

\begin{tabular}{|c|c|c|c|c|c|c|}
\hline$\star \star \star \star \star \star$ & 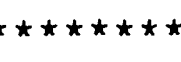 & * RESULT & $\star \star \star \star \star$ & \% ERROR & DET LIMIT & UNITS \\
\hline $\operatorname{Cs} 137$ & & & $1.17 \mathrm{E}-07$ & $4.05 E+01$ & $3.47 E-08$ & $\mathrm{uCi} / \mathrm{g}$ \\
\hline K 40 & & & $2.74 E-05$ & $1.08 E+01$ & $3.13 E-07$ & $\mathrm{uCi} / \mathrm{g}$ \\
\hline $\mathrm{RA2} 26$ & & & $1.43 E-06$ & $1.48 E+01$ & $6.85 E-08$ & $\mathrm{uCi} / \mathrm{g}$ \\
\hline TH228 & & & $2.47 E-06$ & $1.19 E+01$ & $7.56 E-08$ & $\mathrm{uCi} / \mathrm{g}$ \\
\hline TH2 32 & & & $2.18 E-06$ & $1.61 E+01$ & $1.26 E-07$ & $\mathrm{uCi} / \mathrm{g}$ \\
\hline XPEAK & 62.7 & Kev & $2.57 E+00$ & $4.68 E+01$ & $0.00 \mathrm{E}+00$ & $\mathrm{cpm}$ \\
\hline XPEAK & 837.7 & Kev & $6.05 E-01$ & $6.16 E+01$ & $0.00 E+00$ & $\mathrm{cpm}$ \\
\hline XPEAK & 949.4 & Kev & $3.95 E-01$ & $5.78 E+01$ & $0.00 E+00$ & cpm \\
\hline XPEAK & 987.8 & Kev & $3.25 E-01$ & $9.34 E+01$ & $0.00 E+00$ & $\mathrm{cpm}$ \\
\hline XPEAK & 1364.5 & Kev & $3.05 E-01$ & $6.05 E+01$ & $0.00 E+00$ & $\mathrm{cpm}$ \\
\hline XPEAK & 1421.3 & Kev & $1.65 E-01$ & $8.26 E+01$ & $0.00 E+00$ & $\mathrm{cpm}$ \\
\hline XPEAK & 1510.5 & Kev & $2.10 E-01$ & $6.28 E+01$ & $0.00 E+00$ & $\mathrm{cpm}$ \\
\hline XPEAK & 1712.2 & KeV & $1.40 E-01$ & $7.42 E+01$ & $0.00 E+00$ & $\mathrm{cpm}$ \\
\hline XPEAK & 1731.2 & Kev & 3. $00 E-01$ & $5.12 E+01$ & $0.00 \mathrm{E}+00$ & cpm \\
\hline XPEAK & 1956.5 & Kev & $5.50 E-02$ & $2.30 E+02$ & $0.00 E+00$ & $\mathrm{cpm}$ \\
\hline XPEAK & 1973.6 & Kev & $1.75 \mathrm{E}-01$ & $5.94 E+01$ & $0.00 E+00$ & $\mathrm{cpm}$ \\
\hline
\end{tabular}

* * ANALYSIS: H2O_SOIL H2O IN SOIL

IN PROCESS ** 
PROJECT: RES EVENT/PROGRAM: ENVIRONMENTAL SURVEILLANCE SPECIAL STUDIES TYPE: SOIL GROSS (500 ML BOTTLE)

PACKET D5089 ITEM 2

SAMPLE 80982 ID = WELL PM-2 B-SURFACE SAMPLING DATE 111993 COMMENT - - H-3 MDA SHOULD BE 3.E-7 uCi/ml

ANALYSIS $=\mathrm{H}-3$ TRITIUM

PARAMETER $=67861$ SIGMA $=2.0$ SIZE $=1.00 E+01 \quad$ PROCESSED ON 122093

\begin{tabular}{|c|c|c|c|c|}
\hline 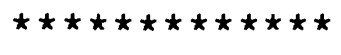 & RESULT & $\star \star$ & \% ERROR & DET LIMIT \\
\hline $1-3$ & & $5.85 E-07$ & $7.67 E+01$ & $4.45 E-07$ \\
\hline
\end{tabular}

PACKET D5089 ITEM 2

SAMPLE 80982 ID= WELL PM-2 B-SURFACE SAMPLING DATE 111993 -

ANALYSIS $=$ GAMMA

COMMENT - - H-3 MDA SHOULD BE 3.E-7 uCi/ml

PARAMETER $=00816$ SIGMA $=2.0 \quad \mathrm{SIZE}=6.82 \mathrm{E}+02 \quad$ PROCESSED ON 113093

\begin{tabular}{|c|c|c|c|c|c|c|}
\hline$\star \star \star$ & $t+t$ & RESULT & $\star \star \star \star \star$ & $\because$ ERROR & DET LIMIT & UNI? \\
\hline AM2 41 & & & $1.71 E-05$ & $9.50 E+00$ & $3.07 E-07$ & $\mathrm{uCi} / \mathrm{g}$ \\
\hline $\mathrm{CO} 60$ & & & $4.50 E-06$ & $1.01 E+01$ & $5.91 E-08$ & $\mathrm{uCi} / \mathrm{g}$ \\
\hline $\operatorname{CS} 137$ & & & $1.05 E-06$ & $1.71 E+01$ & $8.68 E-08$ & $\mathrm{uCi} / \mathrm{g}$ \\
\hline EU150 & & & $1.21 E-06$ & $1.49 \mathrm{E}+01$ & $7.63 E-08$ & $\mathrm{uCi} / \mathrm{g}$ \\
\hline EU152 & & & $1.47 E-05$ & $9.72 \mathrm{E}+00$ & $2.59 E-07$ & $\mathrm{uCi} / \mathrm{g}$ \\
\hline EU154 & & & $1.25 \mathrm{E}-05$ & $1.03 E+01$ & $1.96 \mathrm{E}-07$ & $\mathrm{uCi} / \mathrm{g}$ \\
\hline K 40 & & & $4.20 E-05$ & $1.00 E+01$ & $3.92 \mathrm{E}-07$ & $\mathrm{uCi} / \mathrm{g}$ \\
\hline RA2 26 & & & $8.60 E-07$ & $2.69 E+01$ & $1.46 E-07$ & uCj/g \\
\hline TH228 & & & $2.28 E-06$ & $1.63 E+01$ & $1.70 E-07$ & uCi/g \\
\hline TH232 & & & $2.24 E-06$ & $2.52 E+01$ & $3.41 E-07$ & $\mathrm{uCi} / \mathrm{g}$ \\
\hline XPEAK & 48.8 & Kev & $4.18 E+00$ & $5.15 E+01$ & $0.00 E+00$ & $\mathrm{cpm}$ \\
\hline XPEAK & 93.3 & Kev & $2.26 E+00$ & $9.70 E+01$ & $0.00 E+00$ & $\mathrm{cpm}$ \\
\hline XPEAK & 129.4 & Kev & $1.29 E+00$ & $1.28 E+02$ & $0.00 E+00$ & $\mathrm{cpm}$ \\
\hline XPEAK & 209.2 & Kev & $2.04 E+00$ & $8.09 E+01$ & $0.00 E+00$ & $\mathrm{cpm}$ \\
\hline XPEAK & 232.6 & Kev & $2.43 E+00$ & $6.33 E+01$ & $0.00 E+00$ & $\mathrm{cpm}$ \\
\hline XPEAK & 270.1 & Kev & $2.51 E+00$ & $6.16 E+01$ & $0.00 E+00$ & $\mathrm{cpm}$ \\
\hline XPEAK & 328.4 & Kev & $1.27 E+00$ & $9.54 E+01$ & $0.00 E+00$ & $\mathrm{cpm}$ \\
\hline XPEAK & 367.7 & Kev & $1.33 E+00$ & $7.09 E+01$ & $0.00 E+00$ & $\mathrm{cpm}$ \\
\hline XPEAK & 434.1 & Kev & $1.62 \mathrm{E}+00$ & $5.27 E+01$ & $0.00 E+00$ & $\mathrm{cpm}$ \\
\hline XPEAK & 489.1 & Kev & $9.70 E-01$ & $9.50 E+01$ & $0.00 E+00$ & cpm \\
\hline XPEAK & 564.5 & Kev & $1.23 E+00$ & $7.21 E+01$ & $0.00 E+00$ & cpm \\
\hline XPEAK & 614.4 & Kev & $1.69 E+00$ & $4.91 E+01$ & $0.00 E+00$ & $\mathrm{cpm}$ \\
\hline XPEAK & 625.3 & Kev & $5.80 E-01$ & $1.42 \mathrm{E}+02$ & $0.00 E+00$ & $\mathrm{cpm}$ \\
\hline XPEAK & 649.8 & Kev & $8.85 E-01$ & $8.95 E+01$ & $0.00 E+00$ & cpm \\
\hline XPEAK & 692.5 & Kev & $1.65 E+00$ & $5.08 E+01$ & $0.00 E+00$ & $\mathrm{cpm}$ \\
\hline XPEAK & 860.7 & Kev & $1.29 E+00$ & $6.37 E+01$ & $0.00 E+00$ & $\mathrm{cpm}$ \\
\hline XPEAK & 892.8 & Kev & $9.90 E-01$ & $8.92 E+01$ & $0.00 E+00$ & $\mathrm{cpm}$ \\
\hline XPEAK & 1102.8 & Kev & $7.95 E-01$ & $9.02 E+01$ & $0.00 E+00$ & $\mathrm{cpm}$ \\
\hline XPEAK & 1140.3 & $\mathrm{Kev}$ & $6.55 E-01$ & $8.97 E+01$ & $0.00 E+00$ & $\mathrm{cpm}$ \\
\hline XPEAK & 1233.9 & Kev & $5.70 E-01$ & $7.87 \mathrm{E}+01$ & $0.00 E+00$ & $\mathrm{cpm}$ \\
\hline XPEAK & 1246.4 & Kev & $6.10 E-01$ & $8.33 E+01$ & $0.00 E+00$ & $\mathrm{cpm}$ \\
\hline XPEAK & 1378.1 & $\mathrm{KeV}$ & $3.60 E-01$ & $6.80 E+01$ & $0.00 E+00$ & $\mathrm{cpm}$ \\
\hline XPEAK & 1509.6 & Kev & $1.45 \mathrm{E}-01$ & $1.13 E+02$ & $0.00 E+00$ & $\mathrm{cDm}$ \\
\hline
\end{tabular}


* * LDAS SUMMARY REPORT ON 12-JAN-94 AT 07:42:53 **

PROJECT: RES EVENT/PROGRAM: ENVIRONMENTAL SURVEILLANCE SPECIAL STUDIES TYPE: SOIL GROSS (500 ML BOTTLE)

PACKET D5089 ITEM 2

SAMPLE 80982 ID $=$ WELL PM-2 B-SURFACE XPEAK $1519.5 \mathrm{KeV}$ XPEAK $1588.9 \mathrm{KeV}$ XPEAK $1621.0 \mathrm{KeV}$ XPEAK $1631.4 \mathrm{KeV}$ XPEAK $1638.2 \mathrm{KeV}$ XPEAK $1720.2 \mathrm{KeV}$ XPEAK $1730.5 \mathrm{KeV}$ XPEAK $1742.7 \mathrm{KeV}$ XPEAK $1749.3 \mathrm{KeV}$ XPEAK $1847.8 \mathrm{KeV}$
2. $30 \mathrm{E}-01$

$2.90 \mathrm{E}-01$

3. $30 \mathrm{E}-01$

2. $80 \mathrm{E}-01$

2. $60 \mathrm{E}-01$

2. $10 \mathrm{E}-01$

2. $40 \mathrm{E}-01$

1. 15E-01

8.50E-02

1. $65 \mathrm{E}-01$
SAMPLING DATE 111993 -

8.09E+01 $0.00 \mathrm{E}+00$

7. $27 \mathrm{E}+01 \quad 0.00 \mathrm{E}+00$

$5.30 \mathrm{E}+01 \quad 0.00 \mathrm{E}+00$

$4.51 \mathrm{E}+01 \quad 0.00 \mathrm{E}+00$

$5.60 \mathrm{E}+01 \quad 0.00 \mathrm{E}+00$

8.10E+01 $0.00 \mathrm{E}+00$

$6.56 \mathrm{E}+01 \quad 0.00 \mathrm{E}+00$

1. $11 \mathrm{E}+02 \quad 0.00 \mathrm{E}+00$

1. $44 \mathrm{E}+02$

$6.56 \mathrm{E}+01$
$0.00 \mathrm{E}+00$

$0.00 \mathrm{E}+00$

* * ANALYSIS: H2O_SOIL H2O IN SOIL

cpm

cpm

$\mathrm{cpm}$

$\mathrm{cpm}$

$\mathrm{cpm}$

cpm

cpm

cpm

cpm

cpm

PACKET D5089 ITEM 3

SAMPLE 80984 ID= WELL PM-2 B-30-CM SAMPLING DATE 111993 COMMENT - - H-3 MDA SHOULD BE 3.E-7 uCi/ml

ANALYSIS $=\mathrm{H}-3$ TRITIUM

PARAMETER $=67861$ SIGMA $=2.0$ SIZE $=1.00 E+01 \quad$ PROCESSED ON 122093

\begin{tabular}{|c|c|c|c|c|}
\hline 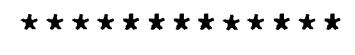 & RESULT & $\star \star$ & $\%$ ERROR & DET LIMIT \\
\hline H-3 TRITIUM & & $6.80 E-06$ & $5.36 E+00$ & $2.34 E-07$ \\
\hline
\end{tabular}

PACKET D5089 ITEM 3

SAMPLE 80984 ID $=$ WELL PM-2 B-30-CM SAMPLING DATE 111993 -

ANALYSIS $=$ GAMMA COMMENT - - H-3 MDA SHOULD BE 3.E-7 uCi/ml

PARAMETER $=00816 \mathrm{SIGMA}=2.0 \mathrm{SIZE}=6.85 \mathrm{E}+02 \quad$ PROCESSED ON 113093

\begin{tabular}{|c|c|c|}
\hline AM2 41 & & \\
\hline $\mathrm{CO} 60$ & & \\
\hline $\operatorname{CS} 137$ & & \\
\hline EU152 & & \\
\hline EU154 & & \\
\hline K 40 & & \\
\hline RA22 6 & & \\
\hline TH228 & & \\
\hline TH232 & & \\
\hline XPEAK & 651.4 & Kev \\
\hline XPEAK & 770.3 & Kev \\
\hline XPEAK & 1027.9 & KeV \\
\hline XPEAK & 1523.0 & Kev \\
\hline XPEAK & 1638.7 & Kev \\
\hline XPEAK & 1749.0 & Kev \\
\hline XPEAK & 1757.0 & Kev \\
\hline XPEAK & 1951.8 & Kev \\
\hline XPEAK & 1960.4 & 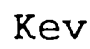 \\
\hline
\end{tabular}

\% ERROR DET LIMIT

$6.16 E-07$
$2.54 E-07$
$1.16 E-06$
$6.36 E-07$
$5.73 E-07$
$4.20 E-05$
$9.09 E-07$
$2.48 E-06$
$2.00 E-06$
$4.10 E-01$
$8.75 E-01$
$2.60 E-01$
$1.10 E-01$
$1.60 E-01$
$1.50 E-01$
$8.50 E-02$
$1.45 E-01$
$1.65 E-01$

$3.38 \mathrm{E}+01$

1. $47 \mathrm{E}-07$

$2.75 \mathrm{E}+01$

3. $86 \mathrm{E}-08$

1. $34 \mathrm{E}+01$

4. $71 \mathrm{E}-08$

3. $14 \mathrm{E}+01$

1. $31 \mathrm{E}-07$

$3.86 \mathrm{E}+01$

1. $52 \mathrm{E}-07$

$9.96 \mathrm{E}+00$

2. $97 \mathrm{E}-07$

1. $90 \mathrm{E}+01$

7. $66 \mathrm{E}-08$

1. $23 E+01$

8. $58 \mathrm{E}-08$

1. $51 \mathrm{E}-07$

$0.00 E+00$

$0.00 E+00$

$0.00 \mathrm{E}+00$

$0.00 \mathrm{E}+00$

$0.00 E+00$

$0.00 E+00$

$0.00 E+00$

$0.00 E+00$

$0.00 E+00$
UNITS

$\mathrm{uCi} / \mathrm{g}$

uCi/g

uCi/g

$\mathrm{uCi} / \mathrm{g}$

$\mathrm{uCi} / \mathrm{g}$

uCi/g

$\mathrm{uCi} / \mathrm{g}$

$\mathrm{uCi} / \mathrm{g}$

$\mathrm{uCi} / \mathrm{g}$

cpm

cpm

cpm

cpm

$\mathrm{cpm}$

$\mathrm{cpm}$

$\mathrm{cpm}$

$\mathrm{cpm}$

cpm 
PROJECT: RES EVENT/PROGRAM: ENVIRONMENTAL SURVEILLANCE SPECIAL STUDIES TYPE: SOIL GROSS (500 ML BOTTLE)

PACKET D5089 ITEM 4

SAMPLE 80986 ID= WELL PM-2 C-SURFACE SAMPLING DATE 111993 -

ANALYSIS $=\mathrm{H}-3$ TRITIUM

COMMENT - - H-3 MDA SHOULD BE 3.E-7 uCi/ml

PARAMETER $=67861$ SIGMA $=2.0$ SIZE $=1.00 E+01 \quad$ PROCESSED ON 122093
$\star \star \star \star \star \star \star \star \star \star \star \star \star$ RESULT
\% ERROR DET LIMIT
UNITS
H- 3 TRITIUM
$6.45 E-06$
$5.38 \mathrm{E}+00$
$2.23 E-07$
$\mathrm{uCi} / \mathrm{g}$

PACKET D5089 ITEM 4

SAMPLE 80986 ID= WELL PM-2 C-SURFACE SAMPLING DATE 111993 -

ANALYSIS $=$ GAMMA

COMMENT - - H-3 MDA SHOULD BE 3.E-7 uCi/ml

PARAMETER $=00816 \mathrm{SIGMA}=2.0 \mathrm{SIZE}=6.86 \mathrm{E}+02 \quad$ PROCESSED ON 113093

\begin{tabular}{|c|c|c|c|c|c|c|}
\hline$\star \star \star$. & 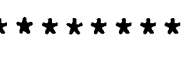 & RESULT & $\star \star$ & \% ERROR & DET LIMIT & UNITS \\
\hline AM2 41 & & & $1.48 E-05$ & $9.74 E+00$ & $2.95 E-07$ & $\mathrm{uCi} / \mathrm{g}$ \\
\hline $\mathrm{Co6} 0$ & & & $3.76 E-06$ & $1.05 \mathrm{E}+01$ & $5.78 E-08$ & uCi/g \\
\hline $\operatorname{CS} 137$ & & & $8.87 E-07$ & $1.81 E+01$ & $8.15 E-08$ & $\mathrm{uCi} / \mathrm{g}$ \\
\hline EU150 & & & $9.89 E-07$ & $1.50 E+01$ & $6.57 E-08$ & $\mathrm{uCi} / \mathrm{g}$ \\
\hline EU152 & & & 1. $34 \mathrm{E}-05$ & $9.84 \mathrm{E}+00$ & $2.45 E-07$ & $\mathrm{uCi} / \mathrm{g}$ \\
\hline EU154 & & & $1.10 E-05$ & $1.06 \mathrm{E}+01$ & $1.98 E-07$ & $\mathrm{uCi} / \mathrm{g}$ \\
\hline K 40 & & & $3.67 E-05$ & $1.03 E+01$ & $3.86 E-07$ & $\mathrm{uCi} / \mathrm{g}$ \\
\hline RA226 & & & 1. $16 \mathrm{E}-06$ & $2.33 E+01$ & $1.50 E-07$ & $\mathrm{uCi} / \mathrm{g}$ \\
\hline TH2 28 & & & $2.48 E-06$ & $1.51 E+01$ & $1.58 E-07$ & $\mathrm{uCi} / \mathrm{g}$ \\
\hline TH2 32 & & & $2.31 E-06$ & $2.38 E+01$ & $3.21 E-07$ & $\mathrm{uCi} / \mathrm{g}$ \\
\hline XPEAK & 92.9 & $\mathrm{KeV}$ & $2.97 E+00$ & $6.85 E+01$ & $0.00 E+00$ & cpm \\
\hline XPEAK & 146.2 & Kev & $1.12 \mathrm{E}+00$ & $1.12 \mathrm{E}+02$ & $0.00 E+00$ & $\mathrm{cpm}$ \\
\hline XPEAK & 209.6 & Kev & $3.03 E+00$ & $5.15 E+01$ & $0.00 E+00$ & cpm \\
\hline XPEAK & 270.3 & Kev & $2.19 E+00$ & $6.65 E+01$ & $0.00 E+00$ & $\mathrm{cpm}$ \\
\hline XPEAK & 328.4 & Kev & 1. $32 E+00$ & $8.57 E+01$ & $0.00 E+00$ & cpm \\
\hline XPEAK & 367.5 & Kev & $1.56 E+00$ & $5.69 E+01$ & $0.00 E+00$ & cpm \\
\hline XPEAK & 433.9 & Kev & $1.13 \mathrm{E}+00$ & $8.39 E+01$ & $0.00 E+00$ & cpm \\
\hline XPEAK & 503.9 & Kev & $7.85 E-01$ & $1.12 E+02$ & $0.00 E+00$ & cpm \\
\hline XPEAK & 845.6 & Kev & $1.20 E+00$ & $6.54 E+01$ & $0.00 E+00$ & cpm \\
\hline XPEAK & 933.9 & Kev & $8.10 \mathrm{E}-01$ & $8.82 E+01$ & $0.00 E+00$ & $\mathrm{cpm}$ \\
\hline XPEAK & 1046.7 & Kev & $1.18 \mathrm{E}+00$ & $6.17 E+01$ & $0.00 E+00$ & $\mathrm{cpm}$ \\
\hline XPEAK & 1128.5 & Kev & $9.55 E-01$ & $6.44 E+01$ & $0.00 E+00$ & $\mathrm{cpm}$ \\
\hline XPEAK & 1236.6 & Kev & $8.75 E-01$ & $6.33 E+01$ & $0.00 E+00$ & cpm \\
\hline XPEAK & 1246.5 & Kev & $5.25 E-01$ & $7.57 E+01$ & $0.00 E+00$ & $\mathrm{cpm}$ \\
\hline XPEAK & 1378.4 & Kev & $5.45 E-01$ & $4.95 E+01$ & $0.00 E+00$ & cpm \\
\hline XPEAK & 1494.6 & Kev & $6.20 E-01$ & $3.96 E+01$ & $0.00 E+00$ & $\mathrm{cpm}$ \\
\hline XPEAK & 1588.5 & Kev & $1.95 E-01$ & $9.44 E+01$ & $0.00 E+00$ & $\mathrm{cpm}$ \\
\hline XPEAK & 1638.0 & Kev & $2.55 E-01$ & $5.42 E+01$ & $0.00 E+00$ & $\mathrm{cpm}$ \\
\hline XPEAK & 1650.6 & Kev & $1.05 E-01$ & $9.18 E+01$ & $0.00 E+00$ & $\mathrm{cpm}$ \\
\hline XPEAK & 1691.4 & Kev & $1.25 E-01$ & 1. $12 E+02$ & $0.00 E+00$ & $\mathrm{cpm}$ \\
\hline XPEAK & 1720.4 & Kev & $3.30 E-01$ & $4.94 E+01$ & $0.00 E+00$ & $\mathrm{cpm}$ \\
\hline XPEAK & 1730.8 & Kev & $2.45 E-01$ & $6.94 E+01$ & $0.00 E+00$ & $\mathrm{cpm}$ \\
\hline XPEAK & 1803.1 & Kev & $2.25 E-01$ & $5.33 E+01$ & $0.00 E+00$ & cpm \\
\hline
\end{tabular}


PROJECT: RES EVENT/PROGRAM: ENVIRONMENTAL SURVEILLANCE SPECIAL STUDIES TYPE: SOIL GROSS (500 ML BOTTLE)

PACKET D5089 ITEM 4

SAMPLE 80986 ID = WELL PM- 2 C-SURFACE

$\begin{array}{llll}\text { XPEAK } & 1840.3 \mathrm{KeV} & 1.75 \mathrm{E}-01 \\ \text { XPEAK } & 1848.3 \mathrm{KeV} & 1.80 \mathrm{E}-01 \\ \text { XPEAK } & 1868.5 \mathrm{KeV} & 1.20 \mathrm{E}-01\end{array}$

SAMPLING DATE $111993-$

$5.57 \mathrm{E}+01 \quad 0.00 \mathrm{E}+00$

cpm

$6.94 \mathrm{E}+01$

$0.00 \mathrm{E}+00$

$9.13 \mathrm{E}+01$

$0.00 \mathrm{E}+00$

$\mathrm{cpm}$

$\mathrm{cpm}$

ANALYSIS: H2O_SOIL H2O IN SOIL

IN PROCESS * *

PACKET D5089 ITEM 5

SAMPLE 80988 ID $=$ WELL PM-2 C-30-CM SAMPLING DATE 111993 COMMENT - - H-3 MDA SHOULD BE 3.E-7 uCi/ml

ANALYSIS $=\mathrm{H}-3$ TRITIUM

PARAMETER $=67861$ SIGMA $=2.0$ SIZE $=1.00 E+01 \quad$ PROCESSED ON 122093

\begin{tabular}{|c|c|c|c|c|}
\hline 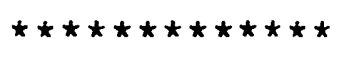 & RESULT & 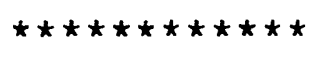 & $\div$ ERROR & DET LIMIT \\
\hline-3 & & $2.38 E-05$ & $3.01 E+00$ & $3.34 E-07$ \\
\hline
\end{tabular}

PACKET D5089 ITEM 5

SAMPLE 80988 ID = WELL PM-2 C-30-CM SAMPLING DATE 111993 -

ANALYSIS $=$ GAMMA

COMMENT - - H-3 MDA SHOULD BE 3.E-7 uCi/ml

PARAMETER $=00816 S I G M A=2.0$ SIZE $=2.08 E+02 \quad$ PROCESSED ON 113093

\begin{tabular}{|c|c|c|}
\hline \multicolumn{3}{|l|}{$\operatorname{CS} 137$} \\
\hline K 40 & & \\
\hline RA2 26 & & \\
\hline TH2 28 & & \\
\hline TH2 32 & & \\
\hline XPEAK & 92.5 & $\mathrm{~K} \in$ \\
\hline XPEAK & 151.2 & $\mathrm{Ke}$ \\
\hline XPEAK & 631.8 & $\mathrm{~K} \in$ \\
\hline XPEAK & 652.6 & $\mathrm{~K}$ \\
\hline XPEAK & 684.2 & K \\
\hline XPEAK & 787.1 & $\mathrm{~K} \epsilon$ \\
\hline XPEAK & 1003.4 & $\mathrm{~K}$ \\
\hline XPEAK & 1064.0 & Ke \\
\hline XPEAK & 1238.7 & $\mathrm{~K}$ \\
\hline XPEAK & 1409.9 & $\mathrm{~K}$ \\
\hline XPEAK & 1485.7 & $\mathrm{~K}$ \\
\hline XPEAK & 1731.2 & $K$ \\
\hline XPEAK & 1747.9 & \\
\hline XPEAK & 1951.8 & \\
\hline & & \\
\hline
\end{tabular}

$6.14 \mathrm{E}-08$

$1.51 \mathrm{E}-06$

$1.69 \mathrm{E}-07$

$2.64 \mathrm{E}-07$

2. $76 \mathrm{E}-07$

6. 55E- 01

5. $45 \mathrm{E}-01$

2. $05 \mathrm{E}-01$

1. $60 \mathrm{E}-01$

1. $15 \mathrm{E}-01$

2. $35 E-01$

2. 15E-01

1. $05 \mathrm{E}-01$

1. $35 E-01$

9. $00 \mathrm{E}-02$

8. 50E-02

$6.00 \mathrm{E}-02$

1. $10 \mathrm{E}-01$

7. $50 \mathrm{E}-02$

7. $50 \mathrm{E}-02$

\section{\% ERROR}

5. $10 E+01$

3. $65 E+01$

4. $65 \mathrm{E}+01$

3. $29 E+01$

4. $37 E+01$

$9.09 \mathrm{E}+01$

8. $33 E+01$

7. $56 \mathrm{E}+01$

1. $16 \mathrm{E}+02$

1. $17 E+02$

9. $31 \mathrm{E}+01$

$6.24 \mathrm{E}+01$

1. $19 E+02$

7. $80 E+01$

1. $21 E+02$

7. $53 E+01$

9. $05 E+01$

7. $16 E+01$

9. $43 E+01$

8. $34 E+01$
DET LIMIT

UNITS

2. $42 E-08$

$2.68 \mathrm{E}-07$

4. $61 \mathrm{E}-08$

4. $12 E-08$

8. $56 E-08$

$0.00 E+00$

$0.00 E+00$

$0.00 E+00$

$0.00 E+00$

$0.00 E+00$

$0.00 E+00$

$0.00 E+00$

$0.00 E+00$

$0.00 E+00$

$0.00 E+00$

$0.00 \mathrm{E}+00$

$0.00 E+00$

$0.00 E+00$

$0.00 E+00$

$0.00 E+00$
$\mathrm{uCi} / \mathrm{g}$ $\mathrm{uCi} / \mathrm{g}$ $\mathrm{uCi} / \mathrm{g}$ $\mathrm{uCi} / \mathrm{g}$ $\mathrm{uCi} / \mathrm{g}$

cpm

cpm

$\mathrm{cpm}$

$\mathrm{cpm}$

$\mathrm{cpm}$

cpm

$\mathrm{cpm}$

cpm

$\mathrm{cpm}$

$\mathrm{cpm}$

cpm

cpm

cpm

cpm

$\mathrm{cpm}$

* * ANALYSIS: H2O SOIL H2O IN SOIL 
* * LDAS SUMMARY REPORT ON 12-JAN-94 AT 07:42:53 **

PROJECT: RES EVENT/PROGRAM: ENVIRONMENTAL SURVEILLANCE SPECIAL STUDIES TYPE: SOIL GROSS (500 ML BOTTLE)

PACKET D5090 ITEM 0

SAMPLE 80990 ID= WELL PM-2 D-SURFACE SAMPLING DATE 111993 COMMENT - - H-3 MDA SHOULD BE $3 . \mathrm{E}-7 \mathrm{uCi} / \mathrm{ml}$

ANALYSIS $=\mathrm{H}-3$ TRITIUM

PARAMETER $=67861$ SIGMA $=2.0$ SIZE $=1.00 E+01 \quad$ PROCESSED ON 122093

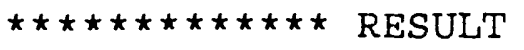
\% ERROR DET LIMIT
UNITS
H- 3 TRITIUM
1.70E-05
$2.96 E+00$
$2.34 E-07$
$\mathrm{uCi} / \mathrm{g}$

PACKET D5090 ITEM 0

SAMPLE 80990 ID= WELL PM-2 D-SURFACE SAMPLING DATE 111993 -

ANALYSIS $=$ GAMMA

COMMENT - - H-3 MDA SHOULD BE 3.E-7 uCi/ml

PARAMETER $=00816$ SIGMA $=2.0$ SIZE $=7.87 E+02 \quad$ PROCESSED ON 113093

\begin{tabular}{|c|c|c|c|c|c|c|}
\hline \multicolumn{2}{|c|}{ 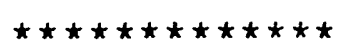 } & * RESULT & $\star \star \star \star$ & $\%$ ERROR & DET LIMIT & UNITS \\
\hline $\mathrm{AM} 241$ & & & $9.09 E-06$ & $1.09 E+01$ & $2.67 E-07$ & $\mathrm{uCi} / \mathrm{g}$ \\
\hline $\mathrm{CO} 60$ & & & $2.80 E-06$ & $1.10 E+01$ & $4.83 E-08$ & $\mathrm{uCi} / \mathrm{g}$ \\
\hline $\operatorname{CS} 137$ & & & $8.01 E-07$ & $1.94 E+01$ & $7.87 E-08$ & $\mathrm{uCi} / \mathrm{g}$ \\
\hline EU150 & & & $7.31 E-07$ & $1.78 E+01$ & $6.38 E-08$ & $\mathrm{uCi} / \mathrm{g}$ \\
\hline EU152 & & & $8.42 E-06$ & $1.08 E+01$ & $2.19 E-07$ & $\mathrm{uCi} / \mathrm{g}$ \\
\hline EU154 & & & $7.18 E-06$ & $1.15 E+01$ & $1.72 E-07$ & $\mathrm{uCi} / \mathrm{g}$ \\
\hline K 40 & & & $4.44 E-05$ & $9.90 E+00$ & $3.70 E-07$ & $\mathrm{uCi} / \mathrm{g}$ \\
\hline $\mathrm{RA} 226$ & & & $8.71 E-07$ & $2.61 E+01$ & $1.33 E-07$ & $\mathrm{uCi} / \mathrm{g}$ \\
\hline TH2 28 & & & $2.35 E-06$ & $1.49 E+01$ & $1.44 E-07$ & $\mathrm{uCi} / \mathrm{g}$ \\
\hline TH232 & & & $2.10 E-06$ & $2.48 E+01$ & $2.95 E-07$ & $\mathrm{uCi} / \mathrm{g}$ \\
\hline XPEAK & 145.4 & Kev & $7.65 E-01$ & $1.78 E+02$ & $0.00 E+00$ & cpm \\
\hline XPEAK & 175.2 & Kev & 1. $22 \mathrm{E}+00$ & 1. $21 E+02$ & $0.00 E+00$ & $\mathrm{cpm}$ \\
\hline XPEAK & 209.0 & Kev & $2.10 E+00$ & $6.74 E+01$ & $0.00 E+00$ & $\mathrm{cpm}$ \\
\hline XPEAK & 258.5 & $\mathrm{KeV}$ & $1.54 \mathrm{E}+00$ & $7.45 \mathrm{E}+01$ & $0.00 E+00$ & cpm \\
\hline XPEAK & 270.3 & Kev & $2.77 E+00$ & $4.66 \mathrm{E}+01$ & $0.00 E+00$ & $\mathrm{cpm}$ \\
\hline XPEAK & 327.5 & Kev & $8.55 E-01$ & $1.02 E+02$ & $0.00 E+00$ & $\mathrm{cpm}$ \\
\hline XPEAK & 367.6 & Kev & $1.11 E+00$ & $7.07 E+01$ & $0.00 E+00$ & $\mathrm{cpm}$ \\
\hline XPEAK & 433.9 & Kev & $1.72 E+00$ & $4.79 E+01$ & $0.00 E+00$ & $\mathrm{cpm}$ \\
\hline XPEAK & 454.1 & Kev & $1.48 E+00$ & $6.01 E+01$ & $0.00 E+00$ & $\mathrm{cpm}$ \\
\hline XPEAK & 546.6 & Kev & $6.40 E-01$ & $1.30 E+02$ & $0.00 E+00$ & $\mathrm{cpm}$ \\
\hline XPEAK & 713.7 & $\mathrm{KeV}$ & $1.12 \mathrm{E}+00$ & $6.51 E+01$ & $0.00 E+00$ & $\mathrm{cpm}$ \\
\hline XPEAK & 904.0 & $\mathrm{Kev}$ & $8.15 E-01$ & $7.91 E+01$ & $0.00 E+00$ & $\mathrm{cpm}$ \\
\hline XPEAK & 989.9 & Kev & $3.65 E-01$ & $1.22 \mathrm{E}+02$ & $0.00 E+00$ & $\mathrm{cpm}$ \\
\hline XPEAK & 1128.8 & Kev & $8.20 E-01$ & $7.31 E+01$ & $0.00 E+00$ & $\mathrm{cpm}$ \\
\hline XPEAK & 1246.4 & $\mathrm{KeV}$ & $5.40 E-01$ & $8.08 E+01$ & $0.00 E+00$ & $\mathrm{cpm}$ \\
\hline XPEAK & 1378.3 & $\mathrm{KeV}$ & $3.40 E-01$ & $5.94 E+01$ & $0.00 E+00$ & $\mathrm{cpm}$ \\
\hline XPEAK & 1397.8 & Kev & $5.10 E-01$ & $4.27 E+01$ & $0.00 E+00$ & $\mathrm{cpm}$ \\
\hline XPEAK & 1495.3 & $\mathrm{KeV}$ & $5.15 E-01$ & $4.10 E+01$ & $0.00 E+00$ & $\mathrm{cpm}$ \\
\hline XPEAK & 1529.5 & Kev & $4.05 E-01$ & $4.55 E+01$ & $0.00 E+00$ & $\mathrm{cpm}$ \\
\hline XPEAK & 1631.7 & Kev & $3.05 E-01$ & $4.93 E+01$ & $0.00 E+00$ & $\mathrm{cpm}$ \\
\hline XPEAK & 1639.9 & Kev & $1.55 \mathrm{E}-01$ & $9.81 E+01$ & $0.00 E+00$ & $\mathrm{cpm}$ \\
\hline XPEAK & 1680.4 & KeV & $1.10 \mathrm{E}-01$ & $8.23 E+01$ & $0.00 E+00$ & $\mathrm{cpm}$ \\
\hline XPEAK & 1720.6 & Kev & 1.70E-01 & $9.20 E+01$ & $0.00 E+00$ & $\mathrm{cpm}$ \\
\hline
\end{tabular}


* LDAS SUMMARY REPORT ON 12-JAN-94 AT 07:42:53

Page 8

PROJECT: RES EVENT/PROGRAM: ENVIRONMENTAL SURVEILLANCE SPECIAL STUDIES TYPE: SOIL GROSS (500 ML BOTTLE)

PACKET D5090 ITEM 0

SAMPLE 80990 ID $=$ WELL PM- 2 D-SURFACE

XPEAK $1848.6 \mathrm{KeV}$

XPEAK $1952.3 \mathrm{KeV}$

2. $40 \mathrm{E}-01$

$1.05 \mathrm{E}-01$

SAMPLING DATE 111993 -

$4.90 \mathrm{E}+01 \quad 0.00 \mathrm{E}+00$

cpm

8. $57 \mathrm{E}+01 \quad 0.00 \mathrm{E}+00$

$\mathrm{cpm}$

* * ANALYSIS: H2O_SOIL H2O IN SOIL

IN PROCESS * *

PACKET D5090 ITEM 1

SAMPLE 80992 ID = WELL PM-2 D-30-CM SAMPLING DATE 111993 -

COMMENT - - H-3 MDA SHOULD BE 3.E-7 uCi/ml

ANALYSIS $=\mathrm{H}-3$ TRITIUM

PARAMETER $=67861$ SIGMA $=2.0$ SIZE $=1.00 E+01 \quad$ PROCESSED ON 122093

\begin{tabular}{|c|c|c|c|}
\hline 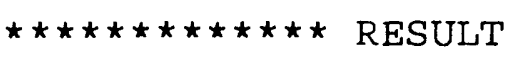 & 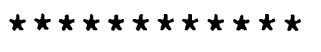 & \% ERROR & DET LIMIT \\
\hline H-3 TRITIUM & $5.07 E-07$ & $9.03 E+01$ & $4.56 \mathrm{E}-07$ \\
\hline
\end{tabular}

PACKET D5090 ITEM 1

SAMPLE 80992 ID = WELL PM-2 D-30-CM SAMPLING DATE 111993 -

ANALYSIS $=$ GAMMA

COMMENT - - H-3 MDA SHOULD BE $3 . \mathrm{E}-7 \mathrm{uCi} / \mathrm{ml}$

PARAMETER $=00816 \mathrm{SIGMA}=2.0 \mathrm{SIZE}=7.49 \mathrm{E}+02 \quad$ PROCESSED ON 113093

\begin{tabular}{|c|c|c|c|c|c|c|}
\hline \multicolumn{2}{|c|}{ 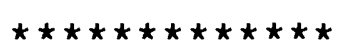 } & * RESULT & 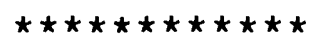 & $\div$ ERROR & DET LIMIT & UNITS \\
\hline $\mathrm{AM} 241$ & & & $3.83 E-06$ & $1.29 E+01$ & $1.81 \mathrm{E}-07$ & $u C i / g$ \\
\hline $\mathrm{CO} 60$ & & & $1.18 E-06$ & $1.40 E+01$ & $4.77 E-08$ & $u C i / g$ \\
\hline $\operatorname{CS} 137$ & & & $7.47 \mathrm{E}-07$ & $1.73 E+01$ & $5.74 E-08$ & $u C i / g$ \\
\hline EU150 & & & $3.13 E-07$ & $2.50 E+01$ & $4.71 E-08$ & $\mathrm{uCi} / \mathrm{g}$ \\
\hline EU152 & & & $3.45 E-06$ & $1.36 \mathrm{E}+01$ & $1.65 \mathrm{E}-07$ & $\mathrm{uCi} / \mathrm{g}$ \\
\hline EU154 & & & $2.97 E-06$ & $1.51 E+01$ & $1.59 \mathrm{E}-07$ & $\mathrm{uCi} / \mathrm{g}$ \\
\hline $\mathrm{K} 40$ & & & $4.22 E-05$ & $9.95 E+00$ & $3.15 \mathrm{E}-07$ & $u \mathrm{Ci} / \mathrm{g}$ \\
\hline RA226 & & & $8.28 E-07$ & $2.31 E+01$ & $1.02 \mathrm{E}-07$ & $\mathrm{uCi} / \mathrm{g}$ \\
\hline TH228 & & & $2.17 E-06$ & $1.42 \mathrm{E}+01$ & $1.18 \mathrm{E}-07$ & $\mathrm{uCi} / \mathrm{g}$ \\
\hline $\mathrm{TH} 232$ & & & $2.09 E-06$ & $1.84 \mathrm{E}+01$ & $1.85 \mathrm{E}-07$ & $u C i / g$ \\
\hline XPEAK & 92.8 & Kev & $1.52 \mathrm{E}+00$ & $8.87 E+01$ & $0.00 E+00$ & $\mathrm{cpm}$ \\
\hline XPEAK & 517.6 & Kev & $7.05 E-01$ & $7.79 E+01$ & $0.00 \mathrm{E}+00$ & $\mathrm{cpm}$ \\
\hline XPEAK & 737.4 & Kev & $6.15 \mathrm{E}-01$ & $8.59 E+01$ & $0.00 \mathrm{E}+00$ & $\mathrm{cpm}$ \\
\hline XPEAK & 770.7 & Kev & $1.14 E+00$ & $5.28 E+01$ & $0.00 E+00$ & $\mathrm{cpm}$ \\
\hline XPEAK & 930.3 & Kev & $7.30 E-01$ & $5.96 E+01$ & $0.00 \mathrm{E}+00$ & $\mathrm{cpm}$ \\
\hline XPEAK & 1067.2 & Kev & $4.55 \mathrm{E}-01$ & $7.79 E+01$ & $0.00 E+00$ & $\mathrm{cpm}$ \\
\hline XPEAK & 1197.6 & Kev & $4.00 \mathrm{E}-01$ & $8.38 E+01$ & $0.00 \mathrm{E}+00$ & $\mathrm{cpm}$ \\
\hline XPEAK & 1377.9 & Kev & $3.00 \mathrm{E}-01$ & $7.74 \mathrm{E}+01$ & $0.00 \mathrm{E}+00$ & $\mathrm{cpm}$ \\
\hline XPEAK & 1398.5 & Kev & $3.35 E-01$ & $6.59 E+01$ & $0.00 E+00$ & $\mathrm{cpm}$ \\
\hline XPEAK & 1449.2 & Kev & 2.10E-01 & $9.59 E+01$ & $0.00 \mathrm{E}+00$ & $\mathrm{cpm}$ \\
\hline XPEAK & 1544.8 & Kev & $1.65 \mathrm{E}-01$ & $5.46 E+01$ & $0.00 \mathrm{E}+00$ & $\mathrm{cpm}$ \\
\hline XPEAK & 1609.1 & Kev & $8.00 \mathrm{E}-02$ & $1.23 E+02$ & $0.00 E+00$ & $\mathrm{cpm}$ \\
\hline XPEAK & 1730.7 & Kev & $2.40 E-01$ & $4.97 E+01$ & $0.00 \mathrm{E}+00$ & $\mathrm{cpm}$ \\
\hline
\end{tabular}

* * ANALYSis: H2O_SOIL H2O IN SOIL

IN PROCESS $\star \star$ 
PROJECT: RES EVENT/PROGRAM: ENVIRONMENTAL SURVEILLANCE SPECIAL STUDIES TYPE: SOIL GROSS (500 ML BOTTLE)

PACKET D5090 ITEM 2

SAMPLE 80994 ID = WELL PM-2 E-SURFACE SAMPLING DATE 111993 -

ANALYSIS $=\mathrm{H}-3$ TRITIUM COMMENT - - H-3 MDA SHOULD BE 3.E-7 uCi/ml

PARAMETER $=67861$ SIGMA $=2.0 \mathrm{SIZE}=1.00 E+01 \quad$ PROCESSED ON 122093

\begin{tabular}{|c|c|c|c|c|}
\hline 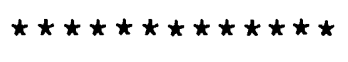 & RESULT & 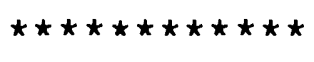 & $\div$ ERROR & DET LIMIT \\
\hline-3 & & $5.25 E-06$ & $6.44 E+00$ & $2.34 \mathrm{E}-07$ \\
\hline
\end{tabular}

PACKET D5090 ITEM 2

SAMPLE 80994 ID = WELL PM-2 E-SURFACE SAMPLING DATE 111993 COMMENT - - H-3 MDA SHOULD BE 3.E-7 uCi/ml

ANALYSIS $=$ GAMMA

PARAMETER $=00816 \mathrm{SIGMA}=2.0 \mathrm{SIZE}=5.90 \mathrm{E}+02 \quad$ PROCESSED ON 113093

AM2 41

$\mathrm{CO} 60$

CS137

EU150

EU152

EU154

K 40

RA2 26

TH2 28

TH2 32

XPEAK $161.6 \mathrm{KeV}$

XPEAK 209.1 KeV

XPEAK $270.4 \mathrm{KeV}$

XPEAK $327.9 \mathrm{KeV}$

XPEAK $433.9 \mathrm{KeV}$

XPEAK $626.0 \mathrm{KeV}$

XPEAK $846.2 \mathrm{KeV}$

XPEAK $880.8 \mathrm{KeV}$

XPEAK $893.6 \mathrm{KeV}$

XPEAK $904.2 \mathrm{KeV}$

XPEAK $948.2 \mathrm{KeV}$

XPEAK $1122.4 \mathrm{KeV}$

XPEAK $1222.3 \mathrm{KeV}$

XPEAK $1246.5 \mathrm{KeV}$

XPEAK $1317.2 \mathrm{KeV}$

XPEAK 1428.1 KeV

XPEAK 1446.2 Kev

XPEAK $1609.3 \mathrm{KeV}$

XPEAK $1631.2 \mathrm{KeV}$

XPEAK 1644.4 KeV

XPEAK $1720.5 \mathrm{KeV}$

XPEAK $1758.1 \mathrm{KeV}$

XPEAK $1984.5 \mathrm{KeV}$
\% ERROR

1. $39 E-05$

2. $55 \mathrm{E}-06$

1. $06 \mathrm{E}-06$

$7.17 \mathrm{E}-07$

1. $00 \mathrm{E}-05$

7.77 E- 06

3. $74 \mathrm{E}-05$

8. 81E-07

2. 07 E-06

1. $81 \mathrm{E}-06$

2. $24 \mathrm{E}+00$

2. $17 \mathrm{E}+00$

1. $60 \mathrm{E}+00$

1. $44 \mathrm{E}+00$

1. $72 \mathrm{E}+00$

6. 40E-01

8.15E-01

6. $20 \mathrm{E}-01$

6. 10E-01

$6.70 \mathrm{E}-01$

8.90E-01

1. $35 \mathrm{E}+00$

6. $65 \mathrm{E}-01$

4. $30 \mathrm{E}-01$

$5.45 \mathrm{E}-01$

3. $30 \mathrm{E}-01$

4. $60 \mathrm{E}-01$

1. $20 \mathrm{E}-01$

2. 35E-01

1. 10E-01

2. 75E-01

8.00E-02

1. 20E-01
9. $49 \mathrm{E}+00$

1. $12 \mathrm{E}+01$

1. $62 \mathrm{E}+01$

1. $72 \mathrm{E}+01$

1. $02 \mathrm{E}+01$

1. $14 \mathrm{E}+01$

1. $03 \mathrm{E}+01$

2. $45 \mathrm{E}+01$

1. $51 \mathrm{E}+01$

2. $34 \mathrm{E}+01$

6. $08 \mathrm{E}+01$

4. $89 \mathrm{E}+01$

6. $49 \mathrm{E}+01$

$7.34 \mathrm{E}+01$

5. $02 \mathrm{E}+01$

9. $92 \mathrm{E}+01$

8. $15 \mathrm{E}+01$

1. $14 \mathrm{E}+02$

1. $03 \mathrm{E}+02$

8. $45 \mathrm{E}+01$

$6.64 \mathrm{E}+01$

4. $35 \mathrm{E}+01$

6. $16 \mathrm{E}+01$

1. $02 \mathrm{E}+02$

5. $35 \mathrm{E}+01$

$6.40 \mathrm{E}+01$

4. $82 \mathrm{E}+01$

1. $02 \mathrm{E}+02$

5. $50 E+01$

1. $08 \mathrm{E}+02$

5. $33 \mathrm{E}+01$

1. $31 \mathrm{E}+02$

$7.07 \mathrm{E}+01$
DET LIMIT

UNITS

$2.37 \mathrm{E}-07$

$4.52 \mathrm{E}-08$

$7.36 \mathrm{E}-08$

$5.88 \mathrm{E}-08$

$2.04 \mathrm{E}-07$

$1.82 \mathrm{E}-07$

3. $63 \mathrm{E}-07$

1. $22 \mathrm{E}-07$

1. $29 \mathrm{E}-07$

2. $55 \mathrm{E}-07$

$0.00 E+00$

$0.00 E+00$

$0.00 E+00$

$0.00 E+00$

$0.00 E+00$

$0.00 E+00$

$0.00 E+00$

$0.00 \mathrm{E}+00$

$0.00 \mathrm{E}+00$

$0.00 \mathrm{E}+00$

$0.00 E+00$

$0.00 \mathrm{E}+00$

$0.00 \mathrm{E}+00$

$0.00 \mathrm{E}+00$

$0.00 E+00$

$0.00 \mathrm{E}+00$

$0.00 \mathrm{E}+00$

$0.00 \mathrm{E}+00$

$0.00 \mathrm{E}+00$

$0.00 \mathrm{E}+00$

$0.00 \mathrm{E}+00$

$0.00 \mathrm{E}+00$

$0.00 E+00$
$\mathrm{uCi} / \mathrm{g}$

$\mathrm{uCi} / \mathrm{g}$

$\mathrm{uCi} / \mathrm{g}$

$\mathrm{uCi} / \mathrm{g}$

$\mathrm{uCi} / \mathrm{g}$

$\mathrm{uCi} / \mathrm{g}$

uCi/g

$\mathrm{uCi} / \mathrm{g}$

$\mathrm{uCi} / \mathrm{g}$

$\mathrm{uCi} / \mathrm{g}$

cpm

$\mathrm{cpm}$

$\mathrm{cpm}$

$\mathrm{cpm}$

$\mathrm{cpm}$

$\mathrm{cpm}$

$\mathrm{cpm}$

$\mathrm{cpm}$

$\mathrm{cpm}$

$\mathrm{cpm}$

$\mathrm{cpm}$

$\mathrm{cpm}$

$\mathrm{cpm}$

$\mathrm{cpm}$

$\mathrm{cpm}$

$\mathrm{cpm}$

$\mathrm{cpm}$

$\mathrm{cpm}$

cpm

$\mathrm{cpm}$

$\mathrm{cpm}$

$\mathrm{cpm}$

$\mathrm{cpm}$

* * ANALySis : H2O_SOIL H2O IN SOIL

IN PROCESS $\star *$ 
* LDAS SUMMARY REPORT ON 12-JAN-94 AT 07:42:53 **

Page 10

PROJECT: RES EVENT/PROGRAM: ENVIRONMENTAL SURVEILLANCE SPECIAL STUDIES TYPE: SOIL GROSS ( $500 \mathrm{ML}$ BOTTLE)

PACKET D5090 ITEM 3

SAMPLE 80996 ID= WELL PM-2 E-30-CM SAMPLING DATE 111993 -

ANALYSIS $=\mathrm{H}-3$ TRITIUM

COMMENT - H-3 MDA SHOULD BE 3.E-7 uCi/ml

PARAMETER $=67861$ SIGMA $=2.0$ SIZE $=1.00 E+01 \quad$ PROCESSED ON 122093

\begin{tabular}{|c|c|c|c|c|}
\hline 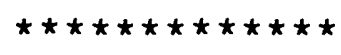 & RESULT & 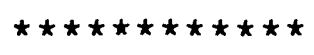 & 官 ERROR & DET LIMIT \\
\hline-3 & & $4.38 E-05$ & $1.77 \mathrm{E}+00$ & $2.45 E-07$ \\
\hline
\end{tabular}

PACKET D5090 ITEM 3

SAMPLE 80996 ID $=$ WELL PM-2 E-30-CM SAMPLING DATE 111993 -

ANALYSIS $=$ GAMMA

COMMENT - - H-3 MDA SHOULD BE 3.E-7 uCi/ml

PARAMETER $=00816 \mathrm{SIGMA}=2.0 \mathrm{SIZE}=5.69 \mathrm{E}+02 \quad$ PROCESSED ON 113093

\begin{tabular}{|c|c|c|c|c|c|}
\hline \multicolumn{2}{|c|}{ 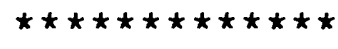 } & & & $\%$ ERRO & DET LIM] \\
\hline $\mathrm{CO} 60$ & & & $8.23 E-08$ & $5.79 E+01$ & $3.79 E-08$ \\
\hline $\operatorname{CS} 137$ & & & $4.49 E-07$ & $1.81 E+01$ & $3.65 E-08$ \\
\hline EU152 & & & $2.54 E-07$ & $5.97 E+01$ & $1.18 \mathrm{E}-07$ \\
\hline EU154 & & & $2.47 E-07$ & $5.78 E+01$ & $1.15 \mathrm{E}-07$ \\
\hline K 40 & & & $2.48 E-05$ & 1. $10 E+01$ & $2.84 \mathrm{E}-07$ \\
\hline RA2 26 & & & $1.05 E-06$ & $1.68 E+01$ & $6.54 \mathrm{E}-08$ \\
\hline TH2 28 & & & $2.07 \mathrm{E}-06$ & $1.26 \mathrm{E}+01$ & $7.21 E-08$ \\
\hline TH232 & & & $1.80 E-06$ & $1.83 E+01$ & $1.37 \mathrm{E}-07$ \\
\hline XPEAK & 106.8 & Kev & $1.46 \mathrm{E}+00$ & $6.05 \mathrm{E}+01$ & $0.00 E+0$ \\
\hline XPEAK & 517.9 & Kev & 3. $70 \mathrm{E}-01$ & $1.01 E+02$ & $0.00 \mathrm{E}+0$ \\
\hline XPEAK & 677.3 & Kev & $4.65 \mathrm{E}-01$ & $5.63 E+01$ & $0.00 E+0$ \\
\hline XPEAK & 783.7 & Kev & $6.23 E-01$ & $5.70 E+01$ & $0.00 E+00$ \\
\hline XPEAK & 932.5 & Kev & $4.65 E-01$ & $6.15 E+01$ & $0.00 E+0 C$ \\
\hline XPEAK & 1086.8 & Kev & $1.90 E-01$ & $1.06 \mathrm{E}+02$ & $0.00 E+0$ \\
\hline XPEAK & 1111.7 & Kev & $3.75 E-01$ & $8.15 E+01$ & $0.00 E+0$ \\
\hline XPEAK & 1343.9 & Kev & $3.70 E-01$ & $4.67 E+01$ & $0.00 E+0$ \\
\hline XPEAK & 1497.0 & Kev & $1.45 E-01$ & $7.66 \mathrm{E}+01$ & $0.00 E+0$ \\
\hline XPEAK & 1510.4 & Kev & $3.20 E-01$ & $4.00 E+01$ & $0.00 E+0$ \\
\hline XPEAK & 1558.4 & Kev & $7.50 E-02$ & $1.25 E+02$ & $0.00 \mathrm{E}+0$ \\
\hline XPEAK & 1570.0 & Kev & $1.50 \mathrm{E}-01$ & $7.60 \mathrm{E}+01$ & $0.00 E+0$ \\
\hline XPEAK & 1662.7 & Kev & $1.15 \mathrm{E}-01$ & $8.61 E+01$ & $0.00 E+0$ \\
\hline XPEAK & 1682.8 & Kev & $1.60 \mathrm{E}-01$ & $6.66 E+01$ & $0.00 E+0$ \\
\hline XPEAK & 1694.2 & Kev & $1.05 \mathrm{E}-01$ & $8.57 E+01$ & $0.00 E+0$ \\
\hline XPEAK & 1742.4 & Kev & $6.00 \mathrm{E}-02$ & $9.13 E+01$ & $0.00 E+0$ \\
\hline XPEAK & 1878.8 & Kev & $1.60 E-01$ & $5.30 E+01$ & $0.00 E+0$ \\
\hline XPEAK & 1893.2 & Kev & $9.50 E-02$ & $6.94 E+01$ & $0.00 E+C$ \\
\hline XPEAK & 1900.5 & Kev & $1.60 \mathrm{E}-01$ & $5.64 E+01$ & $0.00 E+$ \\
\hline XPEAK & 1952.6 & Kev & $1.45 \mathrm{E}-01$ & $7.30 \mathrm{E}+01$ & $0.00 E+C$ \\
\hline
\end{tabular}

* * ANALYSIS: H2O_SOIL H2O IN SOIL

\section{UNITS}

$\mathrm{uCi} / \mathrm{g}$

$\mathrm{uCi} / \mathrm{g}$

$\mathrm{uCi} / \mathrm{g}$

$\mathrm{uCi} / \mathrm{g}$

$\mathrm{uCi} / \mathrm{g}$

$\mathrm{uCi} / \mathrm{g}$

$\mathrm{uCi} / \mathrm{g}$

$\mathrm{uCi} / \mathrm{g}$

cpm

cpm

cpm

cpm

cpm

cpm

cpm

cpm

cpm

cpm

cpm

cpm

cpm

cpm

cpm

$\mathrm{cpm}$

cpm

cpm

cpm

cpm 
* LDAS SUMMARY REPORT ON 12-JAN-94 AT 07:42:53 * *

Page 11

PROJECT: RES EVENT/PROGRAM: ENVIRONMENTAL SURVEILLANCE SPECIAL STUDIES TYPE: SOIL GROSS (500 ML BOTTLE)

PACKET D5090 ITEM 4

SAMPLE 80998 ID $=$ WELL PM-2 F-SURFACE SAMPLING DATE 111993 COMMENT - - H-3 MDA SHOULD BE 3.E-7 uCi/ml

ANALYSIS $=\mathrm{H}-3$ TRITIUM

PARAMETER $=67861$ SIGMA $=2.0$ SIZE $=1.00 E+01 \quad$ PROCESSED ON 122093
$\star \star \star \star \star \star \star \star \star \star \star \star \star \star \star \operatorname{RESULT}$
음 ERROR LIMIT
UNITS
H- 3 TRITIUM
$3.47 \mathrm{E}-06$
$8.81 E+00$
$2.34 E-07$
$\mathrm{uCi} / \mathrm{g}$

PACKET D5090 ITEM 4

SAMPLE 80998 ID $=$ WELL PM-2 F-SURFACE SAMPLING DATE 111993 -

ANALYSIS $=$ GAMMA

COMMENT - - H-3 MDA SHOULD BE 3.E-7 uCi/ml

PARAMETER $=00816 \mathrm{SIGMA}=2.0 \mathrm{SIZE}=5.68 \mathrm{E}+02 \quad$ PROCESSED ON 113093

\begin{tabular}{|c|c|c|}
\hline AM241 & & \\
\hline $\mathrm{CO} 60$ & & \\
\hline $\operatorname{CS} 137$ & & \\
\hline EU150 & & \\
\hline EU152 & & \\
\hline EU154 & & \\
\hline K 40 & & \\
\hline RA2 26 & & \\
\hline TH2 28 & & \\
\hline TH2 32 & & \\
\hline XPEAK & 92.5 & $\mathrm{~K} \in$ \\
\hline XPEAK & 176.5 & $\mathrm{Ke}$ \\
\hline XPEAK & 269.8 & $\mathrm{Ke}$ \\
\hline XPEAK & 306.1 & $\mathrm{~K} \in$ \\
\hline XPEAK & 422.9 & $\mathrm{~K} \in$ \\
\hline XPEAK & 565.0 & $\mathrm{~K} \epsilon$ \\
\hline XPEAK & 714.5 & $\mathrm{~K} \in$ \\
\hline XPEAK & 816.6 & $\mathrm{Ke}$ \\
\hline XPEAK & 839.9 & $\mathrm{Ke}$ \\
\hline XPEAK & 919.8 & $\mathrm{Ke}$ \\
\hline XPEAK & 1153.9 & $\mathrm{Ke}$ \\
\hline XPEAK & 1233.9 & $\mathrm{Ke}$ \\
\hline XPEAK & 1378.4 & $\mathrm{Ke}$ \\
\hline XPEAK & 1448.2 & $\mathrm{Ke}$ \\
\hline XPEAK & 1538.9 & $\mathrm{Ke}$ \\
\hline XPEAK & 1619.0 & $\mathrm{Ke}$ \\
\hline XPEAK & 1692.3 & $\mathrm{Ke}$ \\
\hline XPEAK & 1730.8 & $\mathrm{Ke}$ \\
\hline XPEAK & 1798.3 & $\mathrm{~K}$ \\
\hline XPEAK & 1821.1 & $\mathrm{~K}$ \\
\hline XPEAK & 1839.5 & $\Gamma$ \\
\hline XPEAK & 1848.8 & \\
\hline & & \\
\hline
\end{tabular}

$2.00 \mathrm{E}-05$

$6.23 E-06$

1. $31 \mathrm{E}-06$

1. $81 \mathrm{E}-06$

$2.09 E-05$

1. $73 \mathrm{E}-05$

$3.68 \mathrm{E}-05$

1. $02 \mathrm{E}-06$

1.77E-06

2. $14 \mathrm{E}-06$

$3.49 \mathrm{E}+00$

1. $42 \mathrm{E}+00$

2. $06 \mathrm{E}+00$

1. $79 \mathrm{E}+00$

6. $60 \mathrm{E}-01$

2. $06 \mathrm{E}+00$

1. $03 \mathrm{E}+00$

9. 35E-01

$9.05 \mathrm{E}-01$

1. $04 \mathrm{E}+00$

7. $25 \mathrm{E}-01$

5. $75 \mathrm{E}-01$

3. $80 \mathrm{E}-01$

3. $50 \mathrm{E}-01$

2. 85E-01

3. $05 \mathrm{E}-01$

1. $10 \mathrm{E}-01$

1. $70 \mathrm{E}-01$

7. 50E-02

2. 15E-01

2. 30E-01

2. $45 \mathrm{E}-01$

1. $55 \mathrm{E}-01$
\% ERROR

$9.36 \mathrm{E}+00$

9. $64 \mathrm{E}+00$

1. $72 \mathrm{E}+01$

1. $30 \mathrm{E}+01$

9. $23 \mathrm{E}+00$

9. $74 \mathrm{E}+00$

1. $03 E+01$

2. $95 E+01$

2. $04 E+01$

2. $83 E+01$

6. $82 \mathrm{E}+01$

9. $34 \mathrm{E}+01$

7. $26 \mathrm{E}+01$

8. $50 E+01$

1. $40 \mathrm{E}+02$

5. $58 \mathrm{E}+01$

8. $59 E+01$

8. $76 E+01$

8. $91 E+01$

8. $37 \mathrm{E}+01$

8. $66 \mathrm{E}+01$

9. $38 \mathrm{E}+01$

$7.59 \mathrm{E}+01$

$5.92 \mathrm{E}+01$

$5.98 \mathrm{E}+01$

5. $40 \mathrm{E}+01$

1. $02 \mathrm{E}+02$

7. $58 \mathrm{E}+01$

1. $10 \mathrm{E}+02$

5. $54 \mathrm{E}+01$

5. $61 \mathrm{E}+01$

5. $31 E+01$

8. $44 \mathrm{E}+01$
DET LIMIT

UNITS

3. $41 E-07$

5. 85E-08

1. $06 \mathrm{E}-07$

8. 50E-08

2. $92 \mathrm{E}-07$

2. $08 \mathrm{E}-07$

4. $03 E-07$

1. 88E-07

1. $95 \mathrm{E}-07$

3. $86 \mathrm{E}-07$

$0.00 E+00$

$0.00 E+00$

$0.00 E+00$

$0.00 \mathrm{E}+00$

$0.00 E+00$

$0.00 E+00$

$0.00 E+00$

$0.00 E+00$

$0.00 E+00$

$0.00 E+00$

$0.00 E+00$

$0.00 E+00$

$0.00 E+00$

$0.00 \mathrm{E}+00$

$0.00 \mathrm{E}+00$

$0.00 \mathrm{E}+00$

$0.00 \mathrm{E}+00$

$0.00 \mathrm{E}+00$

$0.00 \mathrm{E}+00$

$0.00 E+00$

$0.00 \mathrm{E}+00$

$0.00 \mathrm{E}+00$

$0.00 \mathrm{E}+00$
$\mathrm{uCi} / \mathrm{g}$

$\mathrm{uCi} / \mathrm{g}$

$\mathrm{uCi} / \mathrm{g}$

$\mathrm{uCi} / \mathrm{g}$

$\mathrm{uCi} / \mathrm{g}$

$\mathrm{uCi} / \mathrm{g}$

$\mathrm{uCi} / \mathrm{g}$

uCi/g

$\mathrm{uCi} / \mathrm{g}$

$\mathrm{uCi} / \mathrm{g}$

cpm

$\mathrm{cpm}$

$\mathrm{cpm}$

$\mathrm{cpm}$

$\mathrm{cpm}$

cpm

cpm

$\mathrm{cpm}$

cpm

$\mathrm{cpm}$

cpm

$\mathrm{cpm}$

cpm

$\mathrm{cpm}$

cpm

$\mathrm{cpm}$

$\mathrm{cpm}$

cpm

$\mathrm{cpm}$

cpm

$\mathrm{cpm}$

cpm

cpm 
* LDAS SUMMARY REPORT ON 12-JAN-94 AT 07:42:53 **

Page 12

PROJECT: RES EVENT/PROGRAM: ENVIRONMENTAL SURVEILLANCE SPECIAL STUDIES TYPE: SOIL GROSS (500 ML BOTTLE)

PACKET D5090 ITEM 5

SAMPLE 81000 ID $=$ WELL PM-2 F-30-CM SAMPLING DATE 111993 COMMENT - H-3 MDA SHOULD BE 3.E-7 uCi/ml

ANALYSIS $=\mathrm{H}-3$ TRITIUM

PARAMETER $=67861$ SIGMA $=2.0$ SIZE $=1.00 E+01 \quad$ PROCESSED ON 122093

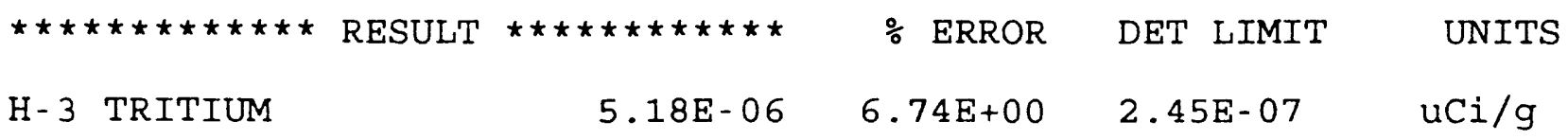

PACKET D5090 ITEM 5

SAMPLE 81000 ID= WELL PM-2 F-30-CM SAMPLING DATE 111993 -

ANALYSIS $=$ GAMMA

COMMENT - - H-3 MDA SHOULD BE 3.E-7 uCi/ml

PARAMETER $=00816 \mathrm{SIGMA}=2.0 \mathrm{SIZE}=6.20 \mathrm{E}+02 \quad$ PROCESSED ON 113093

\begin{tabular}{|c|c|c|c|c|c|c|}
\hline$\star \star \star \star \star$ & 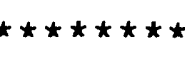 & ULT & 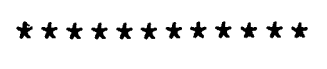 & $\%$ ERROR & DET LIMIT & UNITS \\
\hline AM2 41 & & & $6.05 E-07$ & $3.30 E+01$ & $1.40 E-07$ & $\mathrm{uCi} / \mathrm{g}$ \\
\hline $\mathrm{CO} 60$ & & & $1.71 \mathrm{E}-07$ & $3.45 E+01$ & $3.78 E-08$ & $\mathrm{uCi} / \mathrm{g}$ \\
\hline $\operatorname{CS} 137$ & & & $2.84 E-07$ & $2.46 E+01$ & $3.88 E-08$ & $\mathrm{uCi} / \mathrm{g}$ \\
\hline EU152 & & & $4.63 E-07$ & $3.98 E+01$ & $1.31 E-07$ & $\mathrm{uCi} / \mathrm{g}$ \\
\hline EU154 & & & $4.37 E-07$ & $4.13 E+01$ & $1.25 E-07$ & $\mathrm{uCi} / \mathrm{g}$ \\
\hline K 40 & & & $2.61 E-05$ & $1.09 E+01$ & $2.82 E-07$ & $\mathrm{uCi} / \mathrm{g}$ \\
\hline RA22 6 & & & $1.90 E-06$ & $1.31 E+01$ & $6.28 E-08$ & $\mathrm{uCi} / \mathrm{g}$ \\
\hline TH2 28 & & & $2.14 \mathrm{E}-06$ & $1.27 \mathrm{E}+01$ & $7.93 E-08$ & $\mathrm{uCi} / \mathrm{g}$ \\
\hline TH2 32 & & & 1.80E-06 & $1.92 \mathrm{E}+01$ & $1.52 \mathrm{E}-07$ & $\mathrm{uCi} / \mathrm{g}$ \\
\hline XPEAK & 105.4 & Kev & $1.49 E+00$ & $6.81 \mathrm{E}+01$ & $0.00 E+00$ & $\mathrm{cpm}$ \\
\hline XPEAK & 372.8 & Kev & $4.40 E-01$ & $1.12 \mathrm{E}+02$ & $0.00 E+00$ & $\mathrm{cpm}$ \\
\hline XPEAK & 395.5 & Kev & $7.20 E-01$ & $6.27 \mathrm{E}+01$ & $0.00 E+00$ & cpm \\
\hline XPEAK & 433.8 & Kev & $4.35 \mathrm{E}-01$ & $8.53 E+01$ & $0.00 E+00$ & cpm \\
\hline XPEAK & 639.1 & KeV & $4.75 E-01$ & $7.34 \mathrm{E}+01$ & $0.00 E+00$ & $\mathrm{cpm}$ \\
\hline XPEAK & 806.0 & Kev & $4.90 \mathrm{E}-01$ & $5.66 \mathrm{E}+01$ & $0.00 E+00$ & $\mathrm{cpm}$ \\
\hline XPEAK & 837.9 & Kev & $5.20 E-01$ & $6.68 \mathrm{E}+01$ & $0.00 E+00$ & $\mathrm{cpm}$ \\
\hline XPEAK & 981.0 & Kev & $3.10 E-01$ & $7.99 E+01$ & $0.00 \mathrm{E}+00$ & $\mathrm{cpm}$ \\
\hline XPEAK & 1064.7 & $\mathrm{KeV}$ & $2.50 E-01$ & $1.02 \mathrm{E}+02$ & $0.00 E+00$ & $\mathrm{cpm}$ \\
\hline XPEAK & 1155.9 & Kev & $5.85 E-01$ & $5.50 E+01$ & $0.00 E+00$ & $\mathrm{cpm}$ \\
\hline XPEAK & 1185.5 & Kev & $4.05 E-01$ & $7.97 \mathrm{E}+01$ & $0.00 \mathrm{E}+00$ & $\mathrm{cpm}$ \\
\hline XPEAK & 1402.0 & Kev & $2.00 E-01$ & $8.19 E+01$ & $0.00 E+00$ & $\mathrm{cpm}$ \\
\hline XPEAK & 1510.1 & Kev & $2.40 E-01$ & $6.83 E+01$ & $0.00 E+00$ & $\mathrm{cpm}$ \\
\hline XPEAK & 1554.3 & Kev & $1.25 E-01$ & $9.83 E+01$ & $0.00 E+00$ & cpm \\
\hline XPEAK & 1622.0 & Kev & $1.35 E-01$ & $9.34 \mathrm{E}+01$ & $0.00 E+00$ & $\mathrm{cpm}$ \\
\hline XPEAK & 1730.5 & $\mathrm{Kev}$ & $3.30 \mathrm{E}-01$ & $4.56 \mathrm{E}+01$ & $0.00 E+00$ & $\mathrm{cpm}$ \\
\hline XPEAK & 1848.4 & Kev & $2.65 E-0 I$ & $6.00 E+01$ & $0.00 E+00$ & cpm \\
\hline
\end{tabular}

ANALYSIS: H2O_SOIL H2O IN SOIL 


\section{APPENDIX D. Summary of Hydrologic Testing at Well PM-2}

The information contained in Appendix D was provided from original field notes (R.K. Blankennagel, written commun., 1964). 
Original depth to water: $1,260^{\prime}$

Depth to bridge: $4,070^{\prime}$

Added 125 lbs. salt / 40 bbl water

Run \#1 Brine in at 0615

Salinometer run at 0800

Salt/fresh Interface

$\mathrm{SWL}=1,260^{\prime}$

$\mathrm{WL}=905^{\circ}$

reversal at $1800^{\prime}$ from fresh to salt back to fresh at $2,330^{\circ}$

back to salt at $3,630^{\prime}$

Run \#2 Brine in

SWL $=1,260^{\prime}$

after brine injection:

WL $11 / 4$ hours after injection

$\mathrm{WL}=910^{\prime}(0800)$

$\mathrm{WL}=920^{\prime}(0915)$

SWABBING TESTS $\underline{07 / 12 / 64}$

Specific capacity (gpm/foot of drawdown) not determined because water level continued to decline throughout swabbing period. Swabbing tests proved unnecessary and undesirable

\section{INJECTION TESTS}

Injection test were run on 5 zones believed to be most permeable.

\begin{tabular}{|c|c|}
\hline $\begin{array}{c}\text { Interval Injected, } \\
\text { in feet }\end{array}$ & $\begin{array}{c}\text { Relative } \\
\text { Specific } \\
\text { Capacity }\end{array}$ \\
\hline $2,528-2,726$ & .01 \\
\hline $2,818-3,016$ & 0.00 \\
\hline $3,168-3,366$ & .00 \\
\hline $3,441-3,639$ & .02 \\
\hline $3,720-3,918$ & .00 \\
\hline
\end{tabular}

TRACE]ECTOR TESTS 07/13/64

Tracejector test included the use of Iodine 131 at a concentration of 5 millicuries per 7 milliliters. Records indicate nuclide was emptied from casing at end of test.

\begin{tabular}{|l|l|l|l|l|l|l|l|l|l|l|}
\hline Depth, in feet & 2,450 & 2,574 & 2,896 & 3,190 & 3,336 & 3,560 & 3,650 & 3,760 & 3,896 & 3,950 \\
\hline Flow rate, in gpm & 1.3 & 0.5 & 1.26 & 0.9 & 1.7 & 0.97 & 1.1 & 1.6 & 1.3 & 2.3 \\
\hline
\end{tabular}




\section{APPENDIX E. Summary of Water-Quality Data for Well PM-2 from \\ Lawrence Livermore National Laboratory}

The information contained in Appendix E was provided by Lawrence Livermore National Laboratory. It is presented in the format provided to the USGS. 


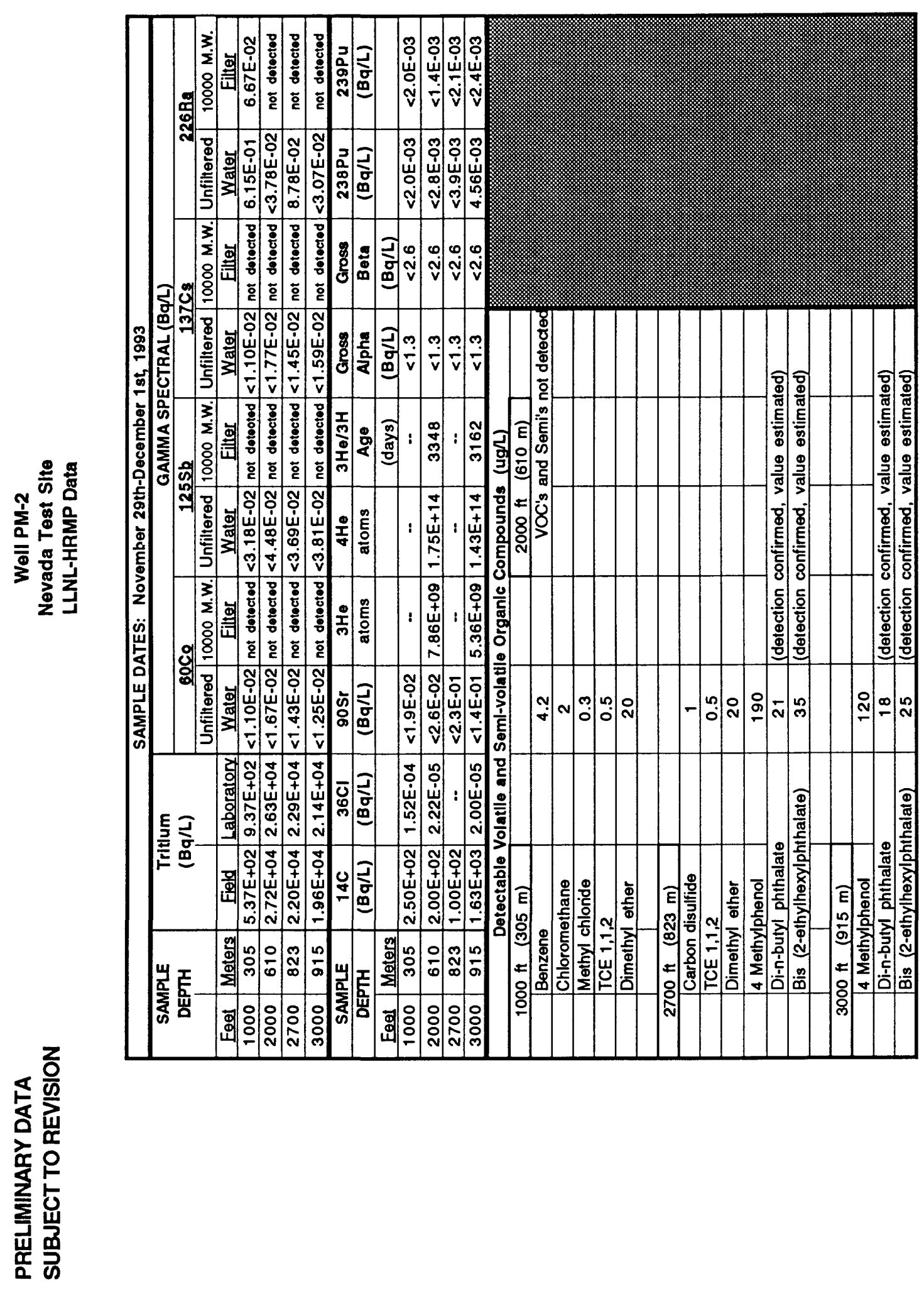




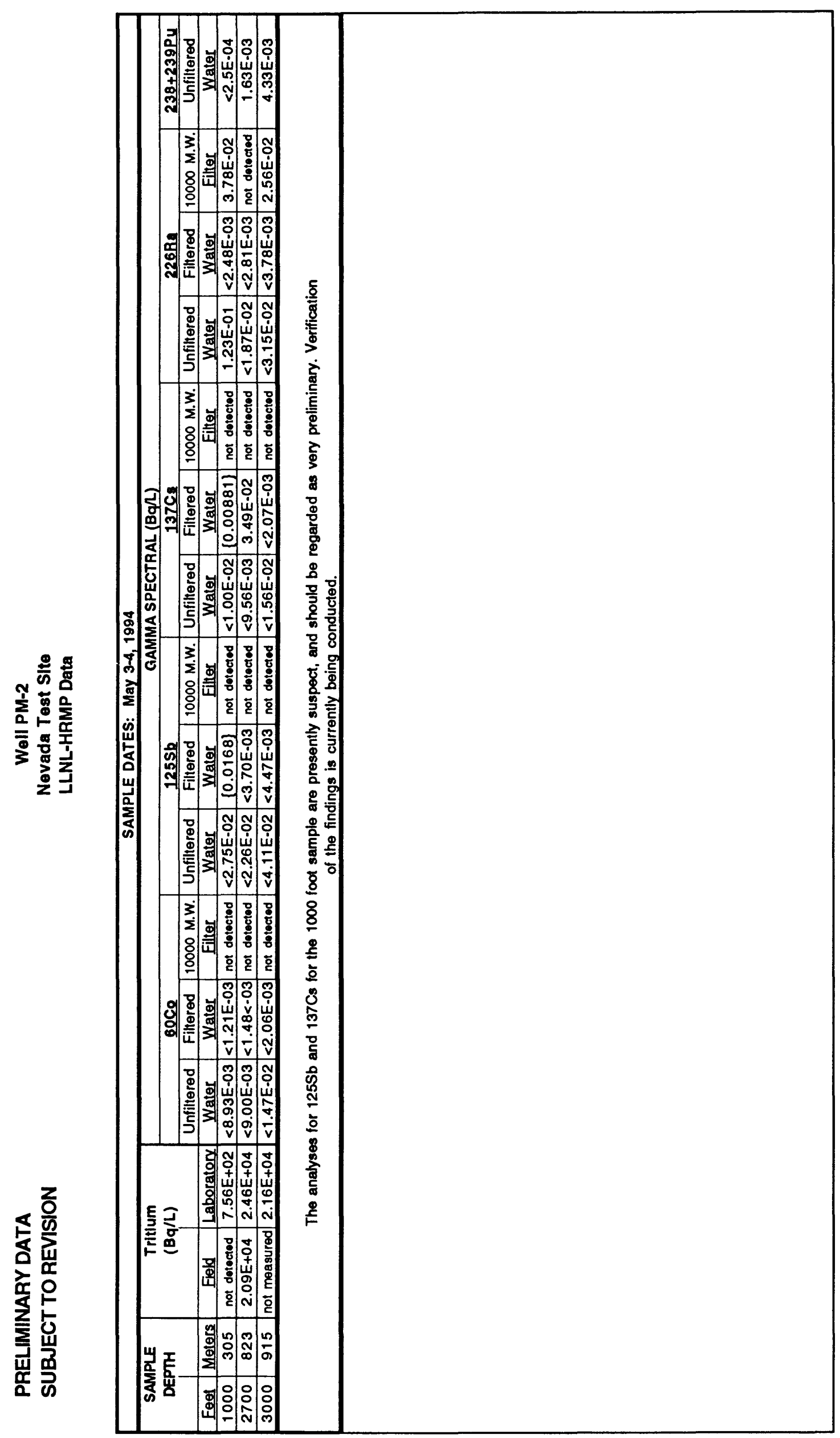




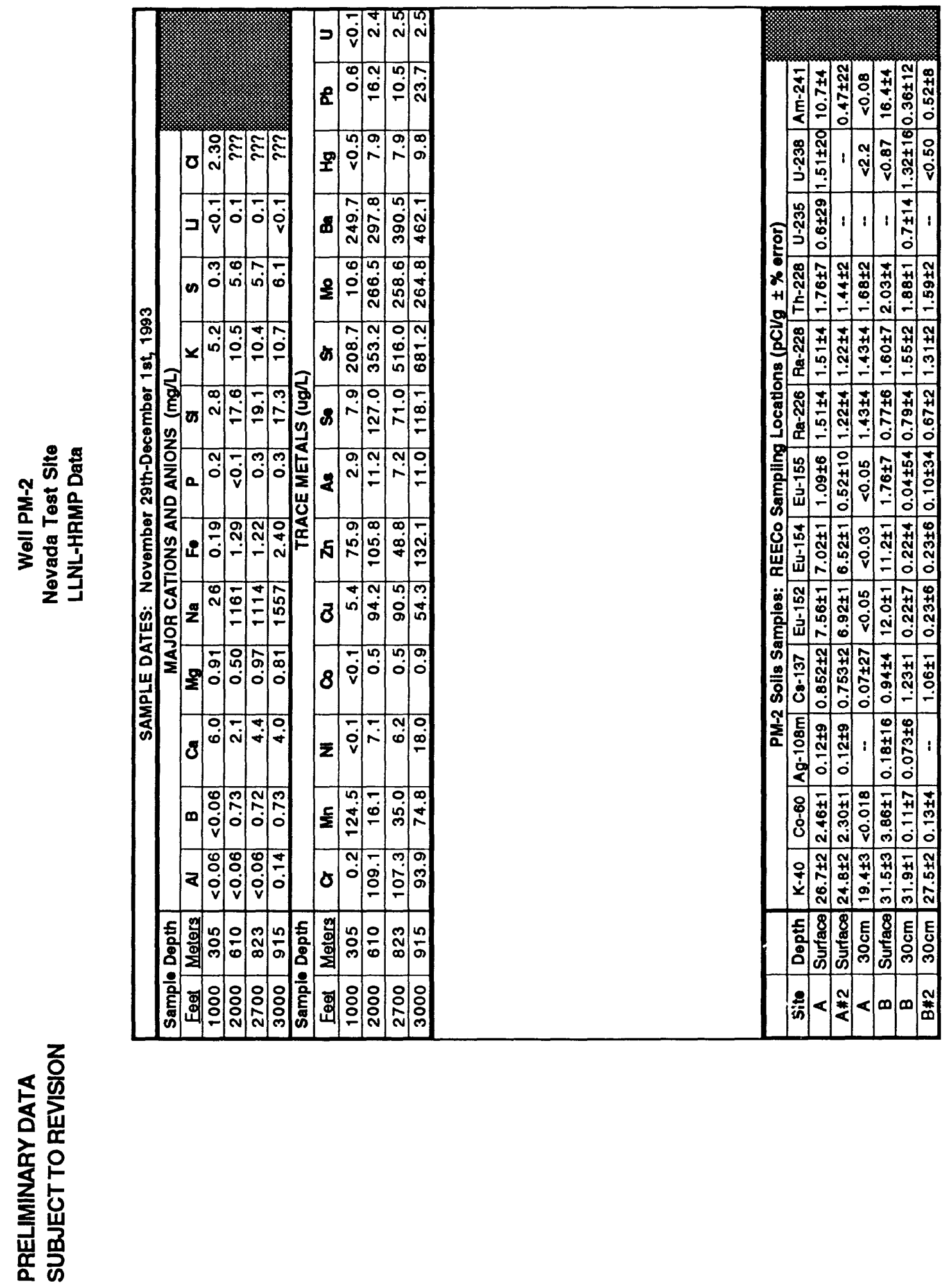




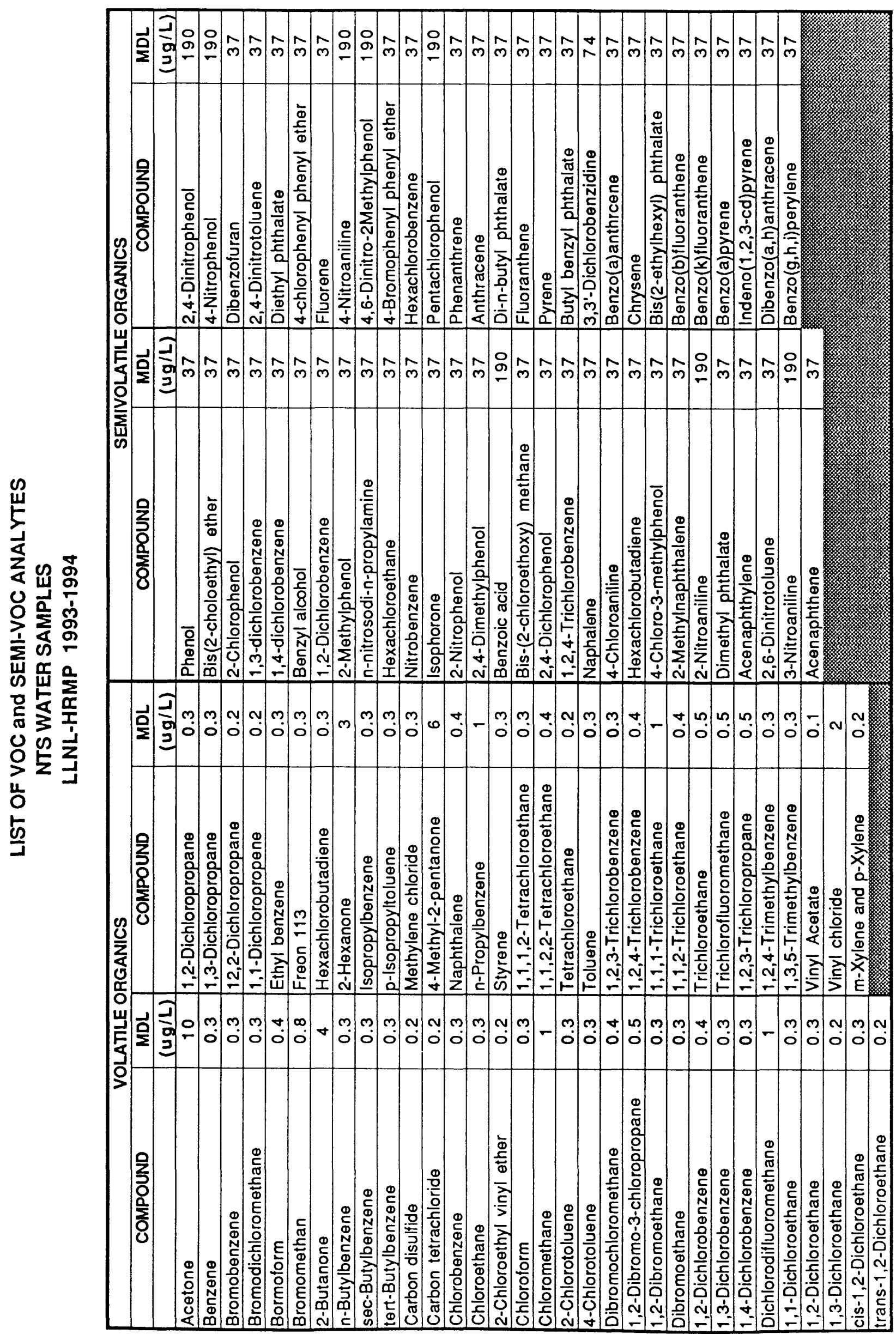


66 Summary of Data Concerning Radiological Contamination at Well PM-2, Nevada Test Site, Nye County, Nevada 


\section{APPENDIX F. Summary of Water-Quality Data for Well PM-2 from Reynolds Electrical \& Engineering Company}

The information contained in Appendix F was provided by Reynold Electrical \& Engineering Co., Inc. It is presented in the format provided to the USGS. 


\section{MEMORANDUM}

To

F. D. Ferate

From

G. A. Clark GAC

Date

November 18, 1993

Subject

SAMPLE ANALYTICAL RESULTS

Enclosed are Analytical Services Department's results for the semivolatile organics and total metals analyses of one water sample collected on September 27, 1993, at Well PM-2 in Area 20.

Please direct any questions you may have about these results to Roger Mitchell (295-7220) or Jerry Dugas (295-7997).

GAC : RNL1282:rn

Enclosures

As stated

cy: Central Files, w/o encls.

A. R. Latham, w/o encls.

L. S. Sygitowicz, w/o encls.

ACS Packet No. 93-11-001, w/0 encls. 
REECO

MISC

REECO

Attn: FRED FERATE

Purchase Order: 1125-022

Invoice Number:
Order \#: 93-11.001

Date: $11 / 18 / 93$ 15:18

Work ID: MTLS,BNA/LIO; A2O, RUSH!

Date Received: $10 / 28 / 93$

Date Completed: $11 / 18 / 93$

Client Code: REECO

REPORT TO FRED FERATE, REECO ASD.

\section{SAMPLE IDENTIFICATION}

\begin{tabular}{|c|c|c|}
\hline Sample & & \\
\hline Number & Description & \\
\hline 01 & $\operatorname{c5} 582 \cdot 3$ & \\
\hline 02 & $93-11-001-Q C 1$ METHOD & BLANK \\
\hline 03 & $93-19-001-0<2$ & INFO_I \\
\hline
\end{tabular}

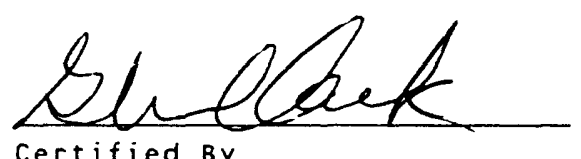


Order \# 93-11-001
$11 / 18 / 93$ 15:18

Sample Description: C5682-3

Test Description: ICP SCAN

Collected: $09 / 27 / 93$

PARAMETER

LITHIUM

BERYLLIUM

BORON

SOOIUM

MAGNESIUM

ALUMINUM

PHOSPHORUS

TITANIUM

VANADIUM

CHROMIUM

MANGANESE

IRON

COBALT

NICKEL

COPPER

ZINC

ARSENIC

SELENIUM

STRONTIUM

MOLYBDENUM

SILVER

CADMIUM

TIN

ANTIMONY

BARIUM

CERIUM

TANTALUM

TUNGSTEN

THALLIUM

LEAD

SILICON

SULFUR

POTASSIUM

CALCIUM

BISMUTH

\section{Lab No: 01B}

Method: ICP

Category: ICPSCN

Test Code: ICPSCN
RESULT

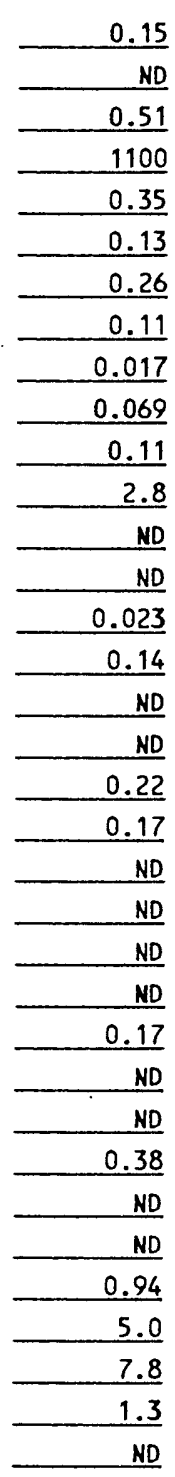

Notes and Definitions for this Report:

ANALYST AJK

UNITS

$\mathrm{mg} / \mathrm{L}$ 
Order \# 93-11-001

$11 / 18 / 93 \quad 15: 18$
REECO ASD/ACS

TEST RESULTS BY SAMPLE
Page 3

Sample Description: 93-11-001-0C2 INFO_I Lab No: 03A

Test Description: INFORMATION FOR INORGANIC Category: ICPSCN_OC Test Code: INFO_I

PARAMETER

PREP_DATE RUN_DATE ANALYSTS

ICP

GFAA

HG (CV)
$11 / 03 / 93 \quad 11 / 04 / 93$ AJK

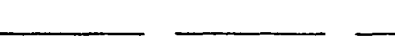


Sample Description: 93-11-001-OC3 DETEC. LIMIT Lab No: 04A

PARAMETER

LITHIUM

BERYLLIUM

BORON

SOOIUM

MAGNESIUM

ALUMINUM

PHOSPHORUS

TITANIUM

VANADIUM

CHROMIUM

MANGANESE

IRON

COBALT

NICKEL

COPPER

ZINC

ARSENIC

SELENIUM

STRONTIUM

MOLYBDENUM

SILVER

CADMIUM

TIN

ANTIMONY

BARIUM

CERIUM

TANTALUM

TUNGSTEN

THALLIUM

LEAD

SILICON

SULFUR

POTASSIUM

CALCIUM

BISMUTH
RESULT

$\begin{array}{r}0.0033 \\ \hline 0.0018 \\ \hline 0.0033 \\ \hline 0.087 \\ \hline 0.048 \\ \hline 0.028 \\ \hline 0.066 \\ \hline\end{array}$

0.0030

0.0078

0.0048

0.0012

0.0027

0.012

0.032

0.0027

0.0015

0.042

0.048

0.0018

0.0027

0.020

0.0042

0.021

0.015

0.0018

0.095

0.039

0.042

0.016

0.035

0.041

0.051

0.438

0.010

0.21

Notes and Definitions for this Report:

ANALYST _ AJK

UNITS 
Sample Description: 93-11-001-CV INST CHK SPK Lab No: 05A

\begin{tabular}{|c|c|}
\hline PARAMETER & RESULT \\
\hline LITHIUM & 98 \\
\hline BERYLLIUM & 96 \\
\hline BORON & 100 \\
\hline SODIUM & 100 \\
\hline MAGNESIUM & 97 \\
\hline ALUMINUM & 101 \\
\hline PHOSPHORUS & 105 \\
\hline TITANIUM & 99 \\
\hline VANADIUM & 98 \\
\hline CHROMIUM & 102 \\
\hline MANGANESE & 103 \\
\hline IRON & 100 \\
\hline COBALT & $N / A$ \\
\hline NICKEL & $N / A$ \\
\hline COPPER & 99 \\
\hline ZINC & 102 \\
\hline ARSENIC & $N / A$ \\
\hline SELENIUM & $N / A$ \\
\hline STRONTIUM & 99 \\
\hline MOLYBDENUM & 100 \\
\hline SILVER & $N / A$ \\
\hline CADMIUM & N/A \\
\hline TIN & $N / A$ \\
\hline ANTIMONY & $N / A$ \\
\hline BARIUM & 100 \\
\hline CERIUM & $N / A$ \\
\hline TANTALUM & $N / A$ \\
\hline TUNGSTEN & 96 \\
\hline THALLIUM & $N / A$ \\
\hline LEAD & $N / A$ \\
\hline SILICON & 140 \\
\hline SULFUR & 100 \\
\hline POTASSIUM & 96 \\
\hline CALCIUM & 100 \\
\hline BISMUTH & $N / A$ \\
\hline
\end{tabular}

Notes and Definitions for this Report:

ANALYST AJK

UNITS \% RECOVERY 
order 93-11-001

$11 / 18 / 9315: 18$
REECO ASD/ACS

REGULAR TEST RESULTS BY TEST
Page 6

BNA ORGANICS (EPA 8270)

Hethod: SW846 8270

Samp Sample Description

$01 A$ C5682-3

Minimum:

Maxi mum:

02A 93-11-001-QC1 METHOD BLANK
Units PACKAGE

PACKAGE 
INORGANIC ANALYST'S NOTES:

Sample number C5682-3 was diluted by the organic branch in order to get enough sample to extract. This diluted sample was given to the inorganic branch to run an ICP metals scan. The sample was diluted by a factor of 2.3, $430 \mathrm{ml}$ of sample diluted to a $\mathrm{final}$ volume of $1000 \mathrm{ml}$. During the preparation of the sample for metals analysis, $100 \mathrm{ml}$ of sample was digested and concentrated down to a final volume of $50 \mathrm{ml}$, or a concentration factor of 2.0. This was done in order to get the sample as close to the original sample concentration as possible. 
ANALY8T NOTES: BNAS

Date:

November 15,1993

Lab work Order No.: 93-11-001

client sample ID.: SBLK1101W (Extraction Blank)

C5682-3

Analyst:

Phil Briggs

The samples were analyzed on a Hewlett Packard $5890 \mathrm{GC} / 5970$

MSD. Data were collected on an HP 1000/RTE-A data system. Instrumental parameters used are those specified in SW-846 3rd edition, September, 1986, METHOD 8270 (for capillary column GC).

The target analytes are listed with their CAS numbers, and the amount of the target compound found in ug/L or $\mathrm{ug} / \mathrm{kg}$, depending on the matrix (water or soil, respectively). If the analyte was not found in the sample, the quantitation limit is reported preceded by an $n$.d. qualifier in the "result" column. The qualifiers used in this reporting format are:

n.d.- Indicates compound was analyzed for but not detected.

$\mathrm{J}$ - Indicates an estimated value. Indicates the presence of a compound that meets the identification criteria, but the result is less than the sample quantitation limit but greater than zero.

B- This flag is used when the analyte is found in the associated blank as well as in the sample. It indicates possible/probable blank contamination.

E- This flag identifies compounds whose concentrations exceed the calibration range of the GC/MS instrument for that specific analysis.

D- This flag identifies all compounds identified in an analysis at a secondary dilution factor.

\section{Case Narrative:}

only $430 \mathrm{mls}$ water were available for extraction instead of the prerequisite liter. The phthalate detected in the sample should probably be considered contamination of it during handling. 
Name Field: C5682-3

Blank:>SD164:PASS QAQC File: QSEMWM Misc Field: 93-11-001-02A $430 \mathrm{ML} / \mathrm{TO} 1 \mathrm{LITER} / / \mathrm{EXTR}$. (DF=2.33) Instrument: BNA1 Datafile: >SD153 Idfile: ID_B1X Quantfile: ^SD153

Injection time: 16:00 on 11-04-93

Continuing calibration time : 08:59 User dilfac:2.33 Quant dilfac:

Quant Time: $16: 43$ on 11-04-93

on 11-04-93 using the file: "SC150::D5 1. Multi-calibration: $09: 25$ on 10-13-93

Compound Name

CAS Number

Result

Detectiol

$=====$
Phenol

bis (2-Chloroethyl) ether

2-Chlorophenol

1,3-Dichlorobenzene

1,4-Dichlorobenzene

Benzyl alcohol

1,2-Dichlorobenzene

2-Methylphenol

$2,2^{\prime}$-oxybis (1-Chloropropane)

bis (2-Chloroisopropy l) ether

4-Methylphenol

N-Nitroso-di-n-propylamine

Hexachloroethane

Nitrobenzene

Isophorone

2-Nitrophenol

2,4-Dimethylphenol

Benzoic acid

bis (2-Chloroethoxy) methane

2,4-Dich lorophenol

1,2,4-Trichlorobenzene

Naphthalene

4-Chloroaniline

Hexach lorobutadiene

4-Chloro-3-methylphenol

2-Methylnaphthalene

Hexachlorocyclopentadiene

2, 4, 6-Trichlorophenol

$2,4,5-T r i c h l o r o p h e n o l$

2-Chloronaphthalene

2-Nitroaniline

Dimethylphthalate

Acenaph thylene

2,6-Dinitrotoluene

3-Nitroaniline

Acenaphthene

2,4-Dinitrophenol

4-Nitrophenol

Dibenzofuran

2,4-Dinitrotoluene

Diethylphthalate

4-Chlorophenyl-phenylether

Fluorene

4-Nitroaniline
$=======$
$108-95-2$

$111-44-4$

95-57-8

541-73-1

106-46-7

$100-51-6$

95-50-1

95-48-7

108-60-1

39638-32-9

106-44-5

$621-64-7$

67-72-1

98-95-3

$78-59-1$

$88-75-5$

$105-67-9$

65-85-0

111-91-1

120-83-2

120-82-1

91-20-3

106-47-8

$87-68-3$

59-50-7

$91-57-6$

$77-47-4$

88-06-2

95-95-4

91-58-7

$88-74-4$

131-11-3

208-96-8

606-20-2

99-09-2

$83-32-9$

$51-28-5$

100-02-7

$132-64-9$

121-14-2

84-66-2

7005-72-3

86-73-7

100-01-6 n.d.

n.d.

n.d.

n.d.

n.d.

n.d.

n.d.

n.d.

n.d.

n.d.

n.d.

n.d.

n.d.

n.d.

n.d.

n.d.

n.d.

n.d.

n.d.

n.d.

n.d.

n.d.

n.d.

n.d.

n.d.

n.d.

n.d.

n.d.

n.d.

n.d.

n.d.

n.d.

n.d.

n.d.

n.d.

n.d.

n.d.

n.d.

n.d.

n.d.

n.d.

n.d.

n.d.

n.d.
Units

UG/L

UG/L

UG/L

UG/L

UG/L

UG/L

UG/L

UG/L

UG/L

$\mathrm{UG} / \mathrm{L}$

UG/L

UG/L

UG/L

UG/L

UG/L

UG/L

UG/L

UG/L

UG/L

UG/L

UG/L

UG/L

UG/L

UG/L

UG/L

UG/L

UG/L

UG / L

UG/L

UG/L

UG/L

UG/L

UG/L

UG/L

UG/L

UG/L

UG/L

UG/L

UG/L

$U G / L$

UG/L

UG/L

UG/L

UG/L
Limit 
EPA 625/8270 Semivolatile Organics Test Results

$$
\text { - Page - } 2
$$

Name Field: C5682-3

Blank:>SD164:PASS QaQC File: QSEMWM Misc Field: 93-11-001-02A $430 \mathrm{ML} / \mathrm{TO} 1 \mathrm{LITER} / / \mathrm{EXTR}$. (DF=2.33)

Instrument: BNA1 Datafile: >SD153 Idfile: ID_B1X Quantfile: ^SD153

\begin{tabular}{|c|c|c|c|c|}
\hline Compound Name & CAS Number & Result & Units & $\begin{array}{l}\text { tecti } \\
\text { Limit }\end{array}$ \\
\hline 4,6-Dinitro-2-methylphenol & $534-52-1$ & n.d. & UG /L & 120 \\
\hline $\mathrm{N}-\mathrm{Nitrosodiphenylamine}$ & $86-30-6$ & n.d. & $\mathrm{UG} / \mathrm{L}$ & 23 . \\
\hline 4-Bromophenyl-phenylether & $101-55-3$ & n.d. & UG/L & 23 . \\
\hline Hexachlorobenzene & $118-74-1$ & n.d. & $\mathrm{uG} / \mathrm{L}$ & 23. \\
\hline Pentachlorophenol & $87-86-5$ & n.d. & $u G / L$ & 120 . \\
\hline Phenanthrene & $85-01-8$ & n.d. & $\mathrm{uG} / \mathrm{L}$ & 23. \\
\hline Anthracene & $120-12-7$ & n.d. & $\mathrm{uG} / \mathrm{L}$ & 23 . \\
\hline Carbazole & $86-74-8$ & n.d. & $\mathrm{uG} / \mathrm{L}$ & 23 . \\
\hline Di-n-butylphthalate & $84-74-2$ & n.d. & $\mathrm{uG} / \mathrm{L}$ & 23. \\
\hline Fluoranthene & $206-44-0$ & n.d. & $\mathrm{uG} / \mathrm{L}$ & 23. \\
\hline Pyrene & $129-00-0$ & n.d. & uG/L & 23. \\
\hline Butylbenzylphthalate & $85-68-7$ & n.d. & uG/L & 23 . \\
\hline $3,3^{\prime}-$ Dichlorobenzidine & $91-94-1$ & n.d. & UG/L & 47 \\
\hline Benzo (a) anthracene & $56-55-3$ & n.d. & $\mathrm{uG} / \mathrm{L}$ & 23. \\
\hline Chrysene & $218-01-9$ & n.d. & $\mathrm{uG} / \mathrm{L}$ & 23. \\
\hline bis (2-Ethylhexyl) phthalate & $117-81-7$ & 54 . & uG/L & 23 . \\
\hline Di-n-octylphthalate & $117-84-0$ & n.d. & $\mathrm{uG} / \mathrm{L}$ & 23. \\
\hline Benzo(b) fluoranthene & $205-99-2$ & n.d. & uG/L & 23. \\
\hline Benzo(k) fluoranthene & $207-08-9$ & n.d. & $\mathrm{uG} / \mathrm{L}$ & 23. \\
\hline Benzo(a) pyrene & $50-32-8$ & n.d. & $\mathrm{uG} / \mathrm{L}$ & 23. \\
\hline Indeno $(1,2,3-c d)$ pyrene & $193-39-5$ & n.d. & uG/L & 23. \\
\hline Dibenzo $(a, h)$ anthracene & $53-70-3$ & n.d. & uG/L & 23 . \\
\hline $\operatorname{Benzo}(g, h, i)$ perylene & $191-24-2$ & n.d. & uG/L & 23 . \\
\hline
\end{tabular}

n.d. - not detected

Approved by: 
Name Field: SBLK1101W

Misc Field: 93-11-001-02A

Instrument: BNA1 Datafile: >SD164
QaQC File: QSEMWM

Idfile: ID_B1X Quantfile: ^SD164
Injection time: 18:29 on 11-10-93

Continuing calibration time : 13:08 on 11-10-93

User dilfac: 1.00 Quant dilfac:
Quant Time: 19:12 on 11-10-93 using the file: "SC158::D3 1. Multi-calibration: $11: 06$ on 11-10-93
Compound Name

Phenol

bis (2-Chloroethyl)ether

2-Chlorophenol

1,3-Dichlorobenzene

1,4-Dichlorobenzene

Benzyl alcohol

1,2-Dichlorobenzene

2-Methylphenol

$2,2^{\prime}$-oxybis (1-Chloropropane)

bis (2-Chloroisopropyl) ether

4-Methylphenol

$\mathrm{N}$-Nitroso-di-n-propylamine

Hexachloroethane

Nitrobenzene

Isophorone

2-Nitrophenol

2,4-Dimethylphenol

Benzoic acid

bis (2-Chloroethoxy) methane

2,4-Dichlorophenol

$1,2,4-T r i c h l o r o b e n z e n e$

Naphthalene

4-Chloroaniline

Hexachlorobutadiene

4-Chloro-3-methylphenol

2-Methylnaphthalene

Hexach lorocyclopentadiene

$2,4,6$-Trichlorophenol

$2,4,5-\mathrm{Tr}$ ichlorophenol

2-Chloronaph thalene

2-Nitroaniline

Dimethylphthalate

Acenaphthylene

2,6-Dinitrotoluene

3-Nitroaniline

Acenaphthene

2,4-Dinitrophenol

4-Nitrophenol

Dibenzofuran

2,4-Dinitrotoluene

Diethylphthalate

4-Chlorophenyl-phenylether

Fluorene

4-Nitroaniline
CAS Number

108-95-2

111-44-4

95-57-8

541-73-1

106-46-7

$100-51-6$

95-50-1

95-48-7

108-60-1

$39638-32-9$

106-44-5

621-64-7

$67-72-1$

$98-95-3$

$78-59-1$

$88-75-5$

$105-67-9$

65-85-0

111-91-1

120-83-2

120-82-1

91-20-3

106-47-8

87-68-3

59-50-7

91-57-6

$77-47-4$

88-06-2

95-95-4

91-58-7

88-74-4

131-11-3

208-96-8

606-20-2

99-09-2

83-32-9

51-28-5

100-02-7

132-64-9

121-14-2

84-66-2

7005-72-3

86-73-7

100-01-6
Result

n.d.

n.d.

n.d.

n.d.

n.d.

n.d.

n.d.

n.d.

n.d.

n.d.

n.d.

n.d.

n.d.

n.d.

n.d.

n.d.

n.d.

n.d.

n.d.

n.d.

n.d.

n.d.

n.d.

n.d.

n.d.

n.d.

n.d.

n.d.

n.d.

n.d.

n.d.

n.d.

n.d.

n.d.

n.d.

n.d.

n.d.

n.d.

n.d.

n.d.

n.d.

n.d.

n.d.

n.d.
Detection Limit

Units

UG/L

UG/L

UG/L

$U G / L$

UG/L

UG/L

UG/L

UG/L

$U G / L$

UG/L

UG/L

UG / L

UG/L

UG / L

UG/L

UG/L

UG/L

UG/L

UG/L

UG / L

UG/L

UG/L

UG/L

UG/L

UG/L

UG/L

UG/L

UG/L

UG/L

UG/L

UG/L

UG/L

UG/L

UG/L

UG/L

UG/L

UG/L

UG/L

UG/L

UG/L

UG/L

UG/L

UG/L

UG/L
10.

10.

10.

10.

10.

10 .

10.

10.

10.

10 .

10.

10.

10.

10.

10.

10.

10.

50.

10.

10.

10.

10.

10 .

10.

10.

10.

10.

10.

50.

10.

50 .

10.

10.

10.

50.

10.

50 .

50.

10.

10.

10.

10.

10.

50. 
EPA $625 / 8270$ Semivolatile organics Test Results

- Page - 2

Name Field: SBLK1101W

QAQC File: QSEMWM

Misc Field: 93-11-001-02A

Instrument: BNA1 Datafile: >SD164 Idfile: ID_B1X Quantfile: ^SD164

\begin{tabular}{|c|c|c|c|c|}
\hline Compound Name & CAS Number & Result & Units & imit \\
\hline 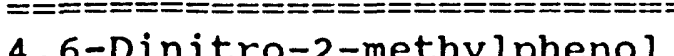 & $=======$ & $n d$ & UCIT & $==$ \\
\hline $\begin{array}{l}\text { 4,6-Dinitro-2-methylphenol } \\
\text { N-Nitrosodiphenylamine }\end{array}$ & $\begin{array}{l}534-52-1 \\
86-30-6\end{array}$ & $\begin{array}{l}n \cdot d \text {. } \\
n \cdot d \text {. }\end{array}$ & $\begin{array}{l}\text { UG / L } \\
\text { UG/L }\end{array}$ & $\begin{array}{l}50 . \\
10 .\end{array}$ \\
\hline 4-Bromophenyl-phenylether & $101-55-3$ & n.d. & $\mathrm{UG} / \mathrm{L}$ & 10. \\
\hline Hexachlorobenzene & $118-74-1$ & n.d. & $\mathrm{UG} / \mathrm{L}$ & 10. \\
\hline Pentachlorophenol & $87-86-5$ & n.d. & UG/L & 50. \\
\hline Phenanthrene & $85-01-8$ & n.d. & uG /L & 10 \\
\hline Anthracene & $120-12-7$ & n.d. & UG/L & 10. \\
\hline Carbazole & $86-74-8$ & n.d. & UG/I & 10. \\
\hline Di-n-butylphthalate & $84-74-2$ & n.d. & UG/L & 10. \\
\hline Fluoranthene & $206-44-0$ & n.d. & uG/L & 10. \\
\hline Pyrene & $129-00-0$ & n.d. & $u G / L$ & 10 \\
\hline Butylbenzylphthalate & $85-68-7$ & n.d. & UG/L & 10. \\
\hline $3,3^{\prime}$-Dichlorobenzidine & $91-94-1$ & n.d. & UG/L & 20. \\
\hline Benzo (a) anthracene & $56-55-3$ & n.d. & uG/L & 10. \\
\hline Chrysene & $218-01-9$ & n.d. & UG/L & 10. \\
\hline bis (2-Ethylhexy l) phthalate & $117-81-7$ & n.d. & UG/L & 10. \\
\hline Di-n-octylphthalate & $117-84-0$ & n.d. & UG/L & 10 \\
\hline Benzo (b) fluoranthene & $205-99-2$ & n.d. & UG/L & 10. \\
\hline Benzo(k) fluoranthene & $207-08-9$ & n.d. & UG/L & 10 . \\
\hline Benzo(a) pyrene & $50-32-8$ & n.d. & UG/L & 10 . \\
\hline Indeno $(1,2,3$-cd) pyrene & $193-39-5$ & n.d. & UG/L & 10. \\
\hline Dibenzo $(a, h)$ anthracene & $53-70-3$ & n.d. & UG/L & 10. \\
\hline Benzo $(g, h, i)$ perylene & $191-24-2$ & n.d. & UG/L & 10 \\
\hline
\end{tabular}

n.d. - not detected

Approved by: 
ACS PACKET NUMBER:

93-11-001

LABORATORY:

REECO-ASD

DATE REVIEWED:

11-18-93
CLIENT: FRED FERATE

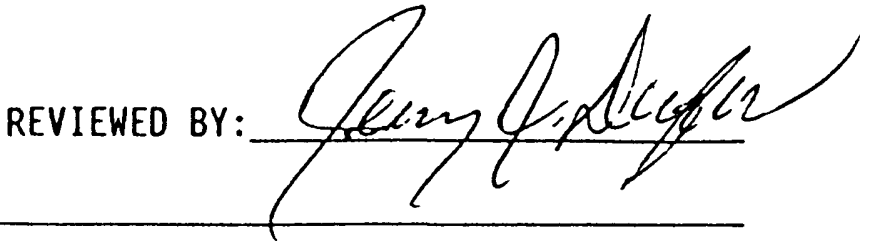

\section{BNA:}

MATRIX: WATER

ARE BNA DATA ACCEPTABLE:

YES

1. TUNE

2. CALIBRATION

3. METHOD BLANK

4. SAMPLES

\begin{tabular}{c} 
SAMPLE NO. \\
\hline DFTPP \\
\hline DFTPP \\
\hline DFTPP \\
\hline INITIAL \\
\hline SSTD050 \\
\hline SSTD050 \\
\hline SBLK1101W \\
\hline C5682-3
\end{tabular}

DATE/TIME

$10-27-93 / 0735$

$11-4-93 / 0821$

$11-10-93 / 0924$

$10-27-93$

$11-4-93 / 0859$

$11-10-93 / 1308$

$11-10-93 / 1829$

$11-4-93 / 1600$

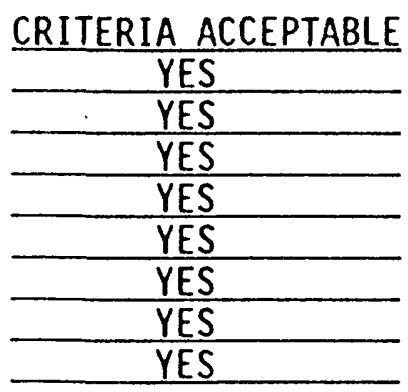

5. SURROGATE RECOVERY ACCEPTABLE:

6. MS/MSD RECOVERY ACCEPTABLE:

7. METHOD BLANK ACCEPTABLE:

8. HOLDING TIMES ACCEPTABLE:

a. Date Sampled:

b. Date ACS Received:

c. Date Contract Lab Received:

d. Date Extracted:

e. Date Analyzed:

9. Correct conc units used:

10. CALCULATIONS ACCEPTABLE:

11. IS AREAS ACCEPTABLE:

12. RRT IS ACCEPTABLE:

13. FORMS ACCEPTABLE:

14. Chain-of-Custody agrees:

9-27-93

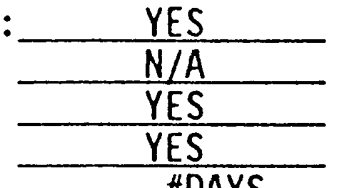

\#DAYS

$\frac{0}{31}$

$N / A$

$\frac{N / A}{\frac{35}{9}}$

$\frac{\frac{\text { ACCEPTABLE }}{0}}{\frac{\text { YES }}{}}$

$\frac{N / A}{\frac{7 *}{40}}$

COMMENTS: HOLD TIME TO EXTRACTION WAS EXCEEDED DUE TO THE LATE DELIVERY OF THE SAMPLE. 


\section{DATA PACKAGE REVIEW}

ACS PACKET NUMBER: $\quad 93-11-001$

LABORATORY:

REECO-ASD

DATE REVIEWED:

11-8-93

CLIENT: FRED FERATE

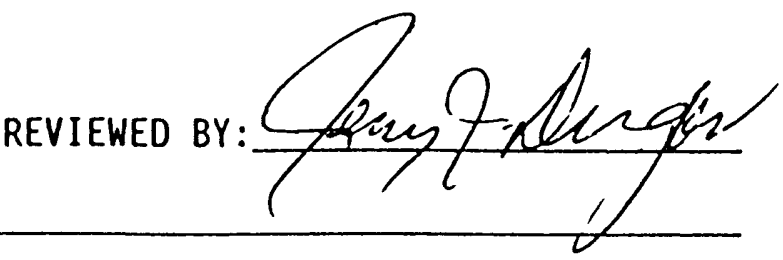

\section{TOTAL METALS}

MATRIX: WATERO

ARE METALS DATA ACCEPTABLE:

YES

1. Are Method Blanks Acceptable:

2. Are Matrix Spikes Acceptable:

3. Are QC Samples Acceptable:

4. Are Holding Times Acceptable:

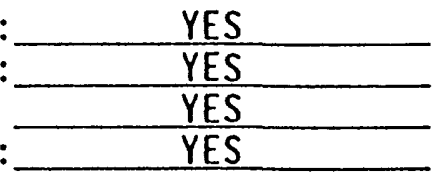

\# DAYS

ACCEPTABLE

a. Sample Date:

b. Date ACS Received:

c. Date Contract Lab Received:

d. Date $\mathrm{Hg}$ Extracted:

e. Date Hg Analyzed:

f. Date Others Extracted:

g. Date Others Analyzed:
$\frac{0}{\mathrm{~N} / \mathrm{A}}$

$\frac{\frac{N / A}{N / A}}{\frac{N / A}{N / A}} \frac{38}{3}$

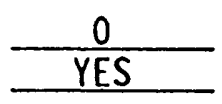

$\frac{\frac{N / A}{N / A}}{\frac{N / A}{N / A}} \frac{180}{1}$

5. Are Forms correct:

6. Are correct conc. units used:

7. Are analyses completed:

8. Chain-of-Custody agrees:

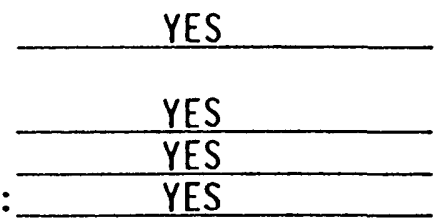

\section{COMMENTS:}


Reynolds Electrical \& Engineering Co., Inc.

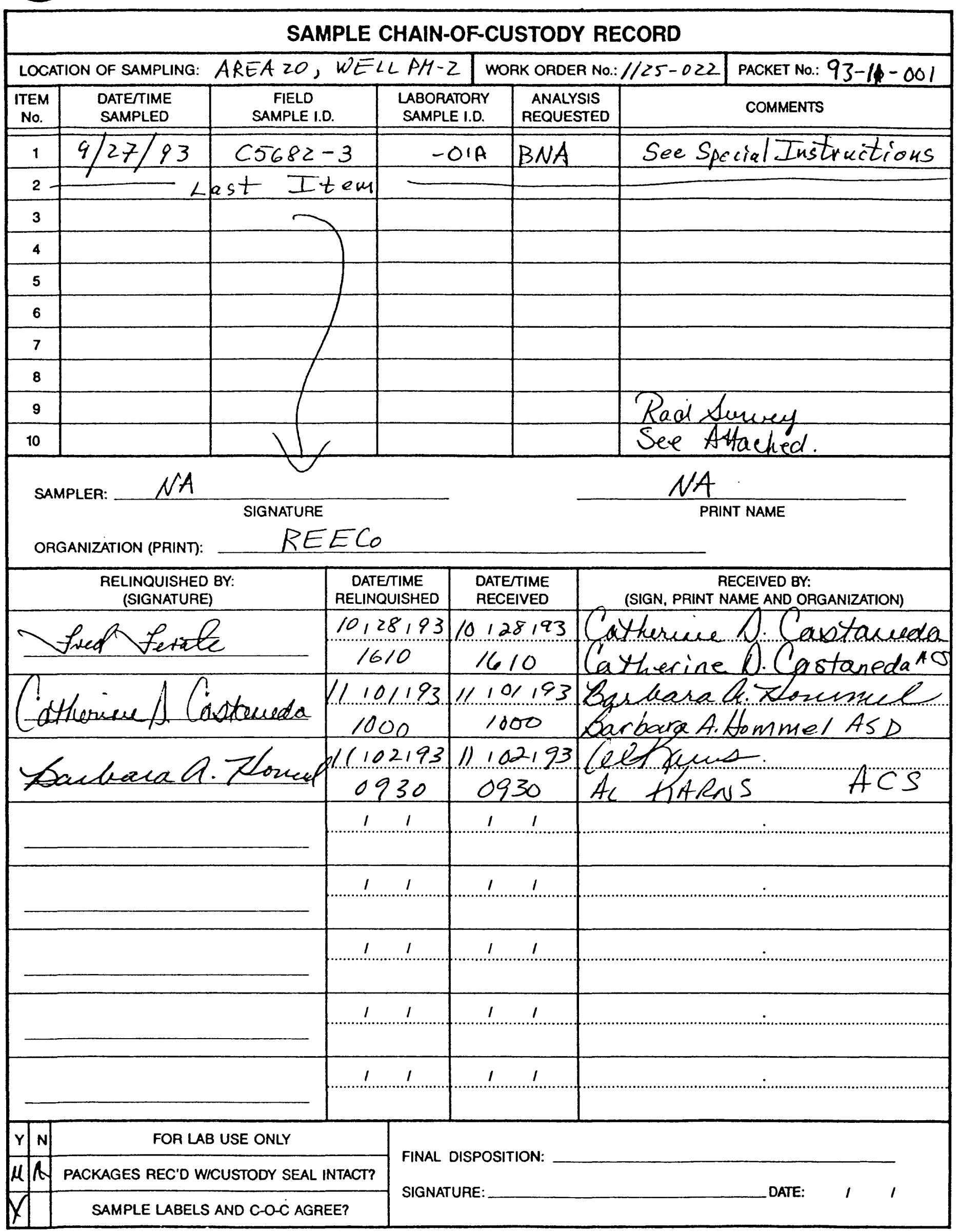

DISTRIBUTION: White (Original) - retained by laboratory performing final analysis

APPENDIX F 83 
REYN DS ELECTRICAL \& ENGINEERII CO., INC.

\section{SAMR LING AND ANALYSIS INFORMATIUN FORM}

\section{PROJECT DESCRIPTION}

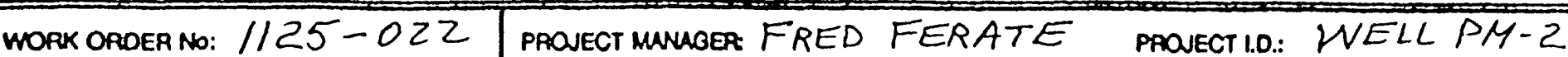

DATE SAMPUNG NEEDEO:

TELEPHONE: $5-7102$ DEPAPTMENT: ASD M/S: 776

SAMPLING LOCATION: WELL PM-2, AREA 20

ONSTIE CONTACT: FRED FERATE

OfFICE LOCATION: MERCURY, BLDG650, PM.142 CONTACt TELEPHONe: $295-7102$

detaleo SITE descaution: WELLPM-2. ON PAHUTE MESA, $270 \mathrm{M}$. FROM

SCHOONER CRATER. SAMPLE TAKEN AT DEPTH OF 2,000 FT, BELOW TOP OE CASING ON $9 / 27 / 93$.

\section{SITE SAFETY, HEALTH, AND RADIOLOGICAL EVALUATION}

RADHOLOGICAL HAZARDS

SAFETY HAZARDS

I. H. HAZARDS

\begin{tabular}{l} 
NO HUZARD \\
$=$ \\
- \\
\hline
\end{tabular}

MAZARDOUS CONDTION EXISTS

- (SEE REVERSE SIDE OF FORM FOR APPPROPRIATE ACTION IF POTENTWL

- HAZARDOUS CONDTION EXSTS)

\section{ANALYSIS DESCRIPTION}

SPECWL INSTRUCTIONS (NUMBER OF SAMPLES, SPECAFI LOCATONS, COMPOSTING REQUIREMENTS, ETC): One Samp/e, Perform CLP-type BNA analysisto determine composition of dark matter. (if pet roleum, whether crude or refined). If liquid not clear after extraction, simult eously initiate ICP metals scan. Try to have results to me by Thurs. Nov. 4, 1993.

\section{REPORT REQUIREMENTS}

DATE FINAL REPORT REQUIREO: $11 / 4 / 93$

PREUMINAFY REPORT REQUIREO? $Y / N$

REPORT TYPE: 1. TARGET COMPOUND (TC) RESULTS ONLY

2. TC AND $O$ RESULTS

(3.) TC AND TENTATMELY IOENTIFIED COMPOUND (TKC) RESULTS
4. TCL, TK AND $\propto$ RESULTS

5. CUP FORMUT REPORT

PPONECT MANAGER SIGNATURE:

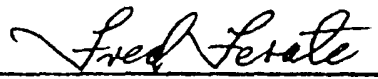

ASO MANAGEMENT CONCURRENCE:

for L.S.Sygitowicz DATE $10,28,93$ LAB DO

FED SAMPLE :

Ref, Packetfitem $05682 / 3$
MATRX

Hubnown
DATE 10,28193

\begin{tabular}{l|l} 
SAMPLE SLEE & $\begin{array}{l}\text { ANLYSES PEQUESTED } \\
\text { METHOO FEQUHRED }\end{array}$
\end{tabular}

\begin{tabular}{lll|l|l|} 
& & & \\
\hline & & & \\
\hline & & & \\
\hline
\end{tabular}
$B N A$, possibly ICP $/ s_{1}$ 